\title{
A Descriptive Analysis of PETE Master's Programs in the U.S. and their Alignment with Advanced Teaching Standards
}

Jamie K. Gilbert

West Virginia University, jkgilbert@mix.wvu.edu

Follow this and additional works at: https://researchrepository.wvu.edu/etd

Part of the Curriculum and Instruction Commons, and the Health and Physical Education Commons

\section{Recommended Citation}

Gilbert, Jamie K., "A Descriptive Analysis of PETE Master's Programs in the U.S. and their Alignment with Advanced Teaching Standards" (2019). Graduate Theses, Dissertations, and Problem Reports. 3771.

https://researchrepository.wvu.edu/etd/3771

This Dissertation is protected by copyright and/or related rights. It has been brought to you by the The Research Repository @ WVU with permission from the rights-holder(s). You are free to use this Dissertation in any way that is permitted by the copyright and related rights legislation that applies to your use. For other uses you must obtain permission from the rights-holder(s) directly, unless additional rights are indicated by a Creative Commons license in the record and/ or on the work itself. This Dissertation has been accepted for inclusion in WVU Graduate Theses, Dissertations, and Problem Reports collection by an authorized administrator of The Research Repository @ WVU.

For more information, please contact researchrepository@mail.wvu.edu. 
A Descriptive Analysis of PETE Master's Programs in the U.S. and their Alignment with Advanced Teaching Standards

\author{
Jamie K. Gilbert \\ Dissertation submitted to the College of Physical Activity and Sport Sciences \\ at West Virginia University \\ in partial fulfillment of the requirements for the degree of \\ Doctor of Education In \\ Kinesiology \\ Emphasis in Coaching and Teaching Studies \\ Valerie Wayda, Ed.D., Co-Chair \\ Sean Bulger, Ed.D., Co-Chair \\ Andrea Taliaferro, Ph.D. \\ Emily Jones, Ph.D. \\ John Oughton, Ed.D.
}

Department of Teaching and Coaching Studies

Morgantown, West Virginia

2019

Keywords:

Physical Education Teacher Education (PETE), Teacher Candidate (TC), Structural Issues, Pedagogical Content Knowledge (PCK) Mode of Instructional Delivery, Traditional Delivery Mode, Hybrid or Blended Curriculum, Hybrid or Blended Course, Curricular Model, Initial Teacher Certification

Copyright 2019 Jamie Gilbert 


\title{
Abstract \\ A Descriptive Analysis of PETE Master's Programs in the U.S. and their Alignment with Advanced Teaching Standards
}

\begin{abstract}
Jamie K. Gilbert
Background: This study provided a descriptive analysis of PETE master's degree programs in the United States. Program demographics and curriculum alignment with SHAPE America's three advanced teaching standards and four guiding principles were the focus of this research.

Methods: This research utilized a non-experimental, cross-sectional descriptive research design and a two-phase approach to collect data. The quantitative survey component analyzed the demographics of programs $(n=13)$ using descriptive analysis. Phone-based semi-structured interviews were conducted to collect data from program affiliates $(n=4)$ concerning program adherence to three advanced PETE standards and four guiding principles.
\end{abstract}

Results: Public universities granting masters and doctoral degrees predominantly offer PETE masters programs as opposed to private liberal arts colleges. Primarily Caucasian faculty with earned terminal degrees and K-12 teaching experience instruct in the majority of programs. The method of instructional delivery contained some online component offered at all universities. All participating universities indicated high priority or essential focus on the components comprising the advanced standards. Programs' direct alignment with SHAPE America's advanced standards varied. Reasons for this variation link directly to programs offering initial certification versus training practicing teachers, and enrollment management. Four themes emerged from the qualitative data including leadership development, curriculum mapping, inquiry-based learning, and enrollment management. Within inquiry-based learning, interviewees indicated a strong focus on teaching effectiveness through a data-driven approach to analyzing teacher behaviors. Additionally, primary emphasis was placed on leadership. Enrollment management presented itself as an integral focal point for program maintenance, as participants indicated a need to tailor programs to masters students unique needs to recruit and retain students.

Conclusions: Many PETE masters programs participating in this research have not been designed intentionally around SHAPE America's advanced standards. None of the programs required teaching experience for admission; however, some required initial licensure for admission, which means that masters level programs offering initial certification should base their curriculum around SHAPE America's initial teaching standards as opposed to advanced. The enrollment management focus is directly tied to the lack of adherence to SHAPE America's advanced standards, as programs have altered admission requirements admit students without initial licensure to maximize enrollment potential. Additionally, a full to partial online component to PETE master's degree programs is quickly becoming widespread from an enrollment management standpoint. 


\section{Dedication}

I dedicate this work to my parents, Edge and Kathy Gilbert who have been a constant source of love and support in my life. I would not be the person that I am without you. To my grandparents, Ann and Stanley Kumor, Gino and Emma Giberti, and Katie Gilbert.

To my Grandpap Kumor: With a $6^{\text {th }}$ grade education, you defied the odds as a successful businessmen and politician. You saw the value in education and took a pride in seeing your grandchildren excel academically. I regret that you passed away too soon to see me receive my diplomas and start my career as a public-school educator. I took my passion for learning and drive for success further and began my career in academia. I wish you'd been here to see me achieve my short-term goal of tenure track assistant professor, and to watch me advance throughout my career into my long-term goals. You and my dad taught us the value of a dollar and the importance of a strong retirement plan. I hope I've made you and my dad proud with the work ethic that you both instilled in me. This one is for you, Pap. 


\section{Acknowledgements}

Thank you to everyone who has helped me on my path to success and meet my goals throughout this process. From advice, to tough love, to kind words and going out of your way to help, you have all helped me grow as a professional. First, I would like to thank my committee: Dr. Sean Bulger, Dr. Valerie Wayda, Dr. Emily Jones, Dr. Andrea Taliaferro, and Dr. John Oughton.

Dr. Bulger, thank you for your guidance throughout my entire experience as a doctoral student at WVU, and your continued guidance as I move forward in my own career in academia. You've truly helped me emerge as a researcher and a professional. I cannot put a price on the confidence you've instilled in me. Dr. Wayda, thank you for your constant understanding and quick feedback. You have also instilled a confidence in me that will not be forgotten. My last two school years were spent in the K-12 setting, which made progress particularly challenging. You were always there when I needed feedback or advice with a smile on your face (even as I've been close to tears).

Dr. Jones, thank you for providing your wisdom and expertise with qualitative analysis. I will always appreciate the time that you drove almost an hour to meet me so that you and I could work on data analysis for the Greenbrier project. No matter how many years I spend in academia, I'd like to think you'd always be my "qualitative person." To Dr. Taliaferro, I have always looked up to you as a professor, as you and I have similar backgrounds, experiences, and a passion for working with children with special learning needs. Thank you for always being a fair, knowledgeable, and understanding figure throughout this process. Dr. Oughton, thank you for your insightful comments and suggestions throughout this entire process. You made my cognate area of C\&I enjoyable and highly useful as I move forward in my career. You were and always have been extremely approachable and easy to talk to, both throughout my dissertation proposal and my C\&I coursework. To each of my committee members; I have learned immeasurable amounts from you all. I would not be where I am without each and every one of you. I cannot put a price on the valuable experiences gained during my time at WVU. If I could go back and do it all again, I would still choose the College of Physical Activity and Sport Science.

A special thank you goes to Dr. Robert Wiegand. You taught me what work/life balance looks like. Your guidance and sense of humor helped me progress as I taught my first college level courses as a GTA at WVU. Special thanks to fellow doctoral students (now Drs.) Ishonte Allar, Jun Baek, Adam Katchmarchi, and Will Davis for helping me in areas that I was weak, serving as an unwavering source of support, and most importantly your friendship throughout this process. Especially Te and Adam, for example, the times spent laughing with you both may be the most memorable of my friendships made in the doctoral program.

Finally, I would like to thank the following people for their kind words, encouraging conversations, and smiling faces: Robin McKinney, Sherry Binion, Tracy Wheeler, Carol Straight, Dr. Sam Zizzi, and Dean Brooks. 


\section{Table of Contents}

$\begin{array}{ll}\text { Introduction } & 1\end{array}$

$\begin{array}{ll}\text { Purpose Statement } & 5\end{array}$

$\begin{array}{ll}\text { Method } & 6\end{array}$

$\begin{array}{ll}\text { Participants } & 6\end{array}$

$\begin{array}{ll}\text { Instrumentation } & 7\end{array}$

$\begin{array}{ll}\text { Data Collection Procedures } & 9\end{array}$

Data Analysis and Trustworthiness 9

$\begin{array}{ll}\text { Results \& Discussion } & 10\end{array}$

$\begin{array}{ll}\text { Figure } 1 & 11\end{array}$

$\begin{array}{ll}\text { Survey } & 11\end{array}$

$\begin{array}{ll}\text { Institutional Profile } & 11\end{array}$

$\begin{array}{ll}\text { Curriculum Framework } & 15\end{array}$

$\begin{array}{ll}\text { Semi-Structured Interviews } & 19\end{array}$

$\begin{array}{ll}\text { Leadership Development } & 19\end{array}$

$\begin{array}{ll}\text { Curriculum Mapping } & 23\end{array}$

$\begin{array}{ll}\text { Inquiry-Based Learning } & 26\end{array}$

$\begin{array}{ll}\text { Enrollment Management } & 32\end{array}$

Limitations \& Future Directions 35

$\begin{array}{ll}\text { Conclusion } & 36\end{array}$

$\begin{array}{ll}\text { Manuscript References } & 40\end{array}$ 
Tables

Appendix A: Extended Review of Literature

Appendix B: Initial Email to Identify Participants; Preliminary Work

Appendix C: Email to Participants (Consent Letter): Survey

Appendix D: Survey

Appendix E: Interview Guide

Appendix F: Email Recruitment for Interview Phase 


\section{Introduction}

Research shows that undergraduate accreditation requirements have placed a significant focus on the structure and content of undergraduate Physical Education Teacher Education (PETE) programs in the United States (Mawer, 2014). Because of this intense focus, research concerning the structure, demographics, and curriculum content of undergraduate PETE programs is robust. Several studies regarding the features that combine to make up the undergraduate PETE curricular structure, program demographics, and programs' adherence to teaching standards (Ayers \& Housner, 2008; Hetland \& Strand, 2010; Taliaferro, Ayers \& Housner, 2017; Wiegand, Bulger \& Mohr, 2013) have come together to comprise this strong undergraduate curricular focus. Studies by Ayers and Housner (2008), and Taliaferro et al. (2017) outlined continuous development of PETE undergraduate program standard adherence, program descriptions, and formed the preliminary basis for this study. To produce a graduatelevel replica to Ayers and Housner's (2008), and Taliaferro et. al's (2017) studies regarding PETE undergraduate programs, research focuses on PETE master's curricular structure, faculty demographics, and programs' incorporation of advanced standards. When compared to undergraduate counterparts, much less is known about PETE master's degree programs in the United States, including how curriculum aligns with advanced teaching standards, and research concerning ongoing education and its relationship to expertise in teaching physical education is currently not robust (Hooper \& Butler, 2013).

\section{PETE Standards}

SHAPE America-the Society of Health and Physical Educators (formerly AAHPERDAmerican Alliance for Health, Physical Education, Recreation, and Dance) is one of the national authorities on physical education in the United States. SHAPE America oversees the 
development of standards for what teacher candidates (TCs) should know and be able to do upon completion of an accredited PETE program (SHAPE America, 2015). Programs designed for initial teacher licensure must use SHAPE America's initial PETE standards if they want to meet accreditation requirements. Programs providing advanced-level (e.g., master's degree, postinitial licensure) training should use SHAPE America's advanced standards as the guiding framework, and provide evidence that candidates meet all underlying elements of the standards in order for the standard to be met (SHAPE America, 2015).

\section{Advanced PETE Standards and Guiding Principles}

Advanced PETE standards focus on three areas and four foundational guiding principles. Advanced standards were designed to provide a progression from the skills and knowledge required from one standard to the next and designed with the licensed educator in mind. Professional knowledge (standard 1) acts as a foundation. The master's TC must possess and apply content knowledge into professional practice (standard 2). Professional leadership (standard 3) outlines expectations for advanced skills, knowledge, and dispositions to develop the teacher as a professional leader (NASPE, 2009).

Professional knowledge (standard 1) is based on the idea that advanced TCs in physical education (PE) enter the program understanding content knowledge, application, and assessment, helping to form the preliminary base for instruction (NASPE, 2009). Professional practice (standard 2) focuses on validating teachers' ability to integrate and utilize pedagogical skills, professional knowledge, and dispositions acquired during initial teacher preparation. Teacher leadership (standard 3) refers to the skill demonstrated by practicing teachers whose leadership impact extends beyond their classrooms (Danielson, 2006). Nappi (2014) states that the role of 
teacher leader remains undefined mainly due to the wide variety of activities and roles that teachers take part in involving leadership.

To determine programs utilization of SHAPE America's advanced standards, the focus was placed on the four guiding principles extending beyond the three advanced standards: focus on learning rather than teaching, integrated knowledge base, the importance of inquiry, and the role of leadership. The four guiding principles serve as an anchor to each of the three standards. By emphasizing learning rather than teaching, best practice in student assessment becomes an essential part of teacher training. SHAPE America's recommendations to evaluate masters level teachers are evaluation rubrics, thesis assessments, and action research projects (Hargreaves \& Fink, 2006; Huba \& Freed, 2000; NASPE, 2008) where one can truly determine the impact they are having on K-12 student learning and their experiences.

The second principle, integrated knowledge base, states that a forward-thinking teacher possesses a cohesive body of knowledge and skills (SHAPE America, 2015). The seminal works of Berliner (1994) and Clark and Peterson (1986) discussed the importance of an integrated knowledge base related to teaching expertise. Shulman (2013, p. 5) outlined the importance of "knowing teacher justifications and their origin, and how teachers decide curriculum, representation, and how to deal with student misunderstanding," concluding that teachers must be able to describe why content is meaningful, and how content relates to goals in and outside of the discipline in theory and practice.

The third principle of inquiry-based learning emphasizes the teacher as a reflective practitioner. The development of reflective habits in teachers has become an integral part of teacher preparation programs (Horng-Yi, 2014). More recently, reflection has presented itself as a central measure of initial teacher certification. States requiring high stakes performance-based 
assessments to obtain initial certification utilize reflection of planning, instruction, and assessment to determine the TCs ability to modify plans to suit the needs of all students (Metzler, 2014). Though these high stakes assessments with a reflective component are tied to initial certification, constant reflection is essential to progress in the field (Horng-Yi, 2014). The fourth principle focuses on the teachers' role as a professional leader (NASPE, 2009). Recent literature indicates that teacher leadership has gained popularity and connects successful teachers with strong leadership skills (Stein, 2014). Stein (2014) stated that effective teachers as classroom leaders are those who know students, create a productive environment, are accountable for student learning, know how to motivate students and have a future vision for themselves.

\section{Rationale}

Graduate programs in education may offer enhanced in field marketability. Applicationbased programs have been making headway over the last 20 years, beginning predominantly with bachelor's degree programs, and slowly lending themselves to master's degree programs where the focus moves more to refining practice and less to pedagogical coursework reserved typically for undergraduates (Darling-Hammond, 2008). One way for practicing PE teachers to enhance marketability, participate in professional development, and evolve as a dynamic and reflective practitioner is in the form of a PETE master's degree (Arum \& Roksa, 2011; Ott, Baca, Cisneros, \& Bates, 2015; Petrie \& McGee, 2012), however, little is known about the existing graduate programs focusing on PETE preparation. According to Hooper and Butler (2013), little research exists regarding the curriculum profile of PETE master's degree programs. Much of the existing research around PETE master's programs, while rich in valuable information, places a narrow focus on the curricular structure of one program (Bulger, Illig, \& Jones, 2017; Dauenhauer et. al, 
2015; Dauenhauer, Krause, Douglas, Smith, \& Stellino, 2017; Davis \& Hawkins, 2014; Ramsey, Hawkins, Housner, Wiegand, \& Bulger, 2009), and PETE graduate student socialization (Richards, Gaudreault, Simonton \& Simonton, 2018). This research was structured to gain an understanding of the institutional profile and curriculum framework of multiple existing PETE master's programs, and to discuss the guiding framework for SHAPE America's advanced PETE standards with profiled PETE master's programs affiliates to gauge programs adherence to the advanced standards.

\section{Purpose}

This study provides a descriptive analysis of PETE masters programs in the United States. A critical point of interest was whether existing PETE master's curriculum aligned with SHAPE America's advanced teaching standards and their four guiding principles and standards implementation per their intended purpose of training practitioners. Additionally, the

background and experience of faculty teaching in the masters in PETE programs, demographics, required culminating experiences, and their relationship to the SHAPE America advanced standards for PETE is necessary for a more accurate overall description of the PETE master's programs in the United States. This study provides insight into the categories mentioned above to offer a clear understanding of the current structure of master's in PETE programs in the United States.

This research addressed the following questions;

- What is the descriptive profile of PETE master's programs including instructor background and curriculum content?

- Do PETE masters programs align curricula with the SHAPE America advanced teacher standards for professional knowledge professional practice, and 
professional leadership, and/or the four guiding principles used to inform these standards?

Research in this specific area is necessary to make a significant addition to essential findings in PETE master's program literature, gain a greater depth of knowledge regarding the profile of existing PETE master's programs in the United States, and assess PETE master's programs' incorporation of and adherence to SHAPE America's advanced standards.

\section{Method}

A non-experimental, cross-sectional descriptive research design (Ary, Jacobs, Sorensen, \& Walker, 2013) was employed for this study. The quantitative survey component analyzed demographics of PETE master's programs (i.e., instructor background, curriculum content, and method of instructional delivery) using descriptive analysis of frequencies, measures of central tendency, and distribution to answer research question one. A reflective qualitative component analyzed PETE master's programs' use of the four anchors established as the guiding framework for SHAPE America's three advanced standards. An inductive approach to semi-structured telephone interviews was used to answer research question two (Goddard \& Melville, 2004).

\section{Participants}

Twenty-seven program affiliates from colleges and universities offering a master's degree in PETE were recruited to participate using a multiple step sampling procedure. As an initial step in sampling frame construction, the researcher accessed an existent a list of programs from a database of colleges and universities offering a bachelor's degree in PETE (Ayers \& Housner, 2008), and from a search of programs listed at www.gradschools.com. This list was updated and expanded through the completion of an advanced search of the library-college database at a Midwestern university. Following the initial email to the contact person at each 
university offering undergraduate PETE programs, 414 undergraduate coordinators responded indicating that no master's program with an emphasis in PETE offered at their institution (Appendix B). The final list of graduate programs was formed for the specific purpose of this study and included 27 US colleges and universities offering master's degree programs in PETE.

Of the 27 programs contacted, $15(56 \%)$ program representatives agreed to complete the survey. Thirteen (48\%) those respondents replied with usable survey data. Of the 13 respondents, 11 (40\%) completed the survey in its entirety. The 13 respondents were contacted and asked to participate in phone interviews following survey completion. Four of the thirteen respondents agreed to participate in semi-structured phone interviews. All semi-structured interview participants were professors directly affiliated with PETE master's programs.

\section{Instrumentation}

Data was gathered using a two-phase approach. A survey was used to gather demographic profile information about programs offering a master's degree in PETE. Phonebased semi-structured interviews were used for the second form of data collection. The purpose of the phone based semi-structured interviews was to collect data applicable to programs' adherence to the three advanced standards.

Survey instrument. The 29-item survey was based on existing instruments (Ayers \& Housner, 2008; NASPE, 2008; SHAPE America, 2009), and developed for the purpose of this study. Survey questions were designed to secure university demographic information, student characteristics, instructor characteristics and, curriculum makeup. To determine programs' use of each element tied to advanced standards 1-3, participants were given a detailed description of each advanced standard and their guiding principles. Participants were asked to indicate to the level of priority their program gave to each guiding principle throughout its entire curriculum 
using a five-point Likert scale (Allen \& Seaman, 2007) ranging from "not a priority" to "high priority." Allen and Seaman (2007) recommend that it is best to use as wide a response scale as possible.

Given the descriptive nature of the questionnaire, the survey was reviewed by employees of the Applied Research Lab at Indiana University of Pennsylvania and dissertation committee co-chairs to establish content validity. Committee co-chairs provided feedback regarding question content about masters in PETE program structure/content and advanced standards. Two employees of the applied research lab (one professor of mathematics and one graduate teaching assistant in the mathematics department) reviewed the survey extensively on eight separate occasions, providing feedback related to the structure of the survey, question wording, question order, length of the survey, and ease of completion. The instrument was modified 10 times in total to ensure its best form to collect targeted information. A pilot test of the survey was conducted with three PETE professionals in academia who are not currently affiliated with a masters PETE program due to either retirement or promotion to an administrative rank in higher education. The purpose of the pilot was to check the functionality of the instrument and question clarity. Pilot participants were asked about their willingness to participate in the survey pilot. Upon agreement, the invitation to participate (Appendix C) and survey link (Appendix D) were sent to pilot participants via email. Data collected during the pilot test were not included in the final analysis.

Semi-structured interviews. For the second phase of data collection, phone-based semistructured interviews were utilized as a means of collecting data to assess programs' adherence to SHAPE America's advanced standards 1-3 by examining programs use of the four guiding principles. Interviews consisted of six questions attempting to ascertain the program's curricular 
alignment with the advanced standards from the distinct perspective of program affiliates. The researcher conducted a pilot test of the semi-structured interview questions using the same three PETE professionals mentioned in the questionnaire phase to check the functionality of the questions. Semi-structured interview questions were piloted for clarity, formatting, and areas in need of further potential explanation. Results from the piloting of the interview questions were not included in final analysis.

\section{Data Collection Procedures}

Upon approval from West Virginia University's IRB, the researcher contacted to the 27 prospective participants individually with an email stating the purpose of the study, benefits of participation, and a hyperlink to the survey in Qualtrics (Appendix D). The population of interest was small $(N=27)$ warranting distribution of the survey to the entire population (Denscombe, 2014). Other measures to increase the likelihood of increased response included three personalized reminder emails with the link to the survey and sending each program affiliates personalized individual emails (Denscombe, 2014; Dillman, 2011). These actions resulted in a $56 \%$ response rate, and $46 \%$ response rate with useable data. Upon survey submission, program affiliates were contacted via email to participate in a semi-structured phone interview. Participants received a recruitment script via email and copy of interview questions (Appendix E and Appendix F) with the recruitment email. Those consenting participation $(n=4)$ were contacted immediately to schedule a 25-30-minute interview to collect data applicable to their programs' adherence to the advanced PETE standards.

\section{Data Analysis and Trustworthiness}

Survey results were downloaded into Microsoft Excel where the data was reviewed for 
accuracy. Descriptive statistics such as means, percentages, and frequencies were calculated for each of the variables. Means, measures of central tendency, and measures of variability of the data about the average were used when analyzing the instructor profile, student profile, admission criteria, and program profile components of the survey. Measures of central tendency and measures of dispersion were used to inform the final three survey items asking participants to rate their programs' prioritization of advanced standards (Standard 1, Professional Knowledge; Standard 2, Professional Practice; Standard 3, Professional Leadership) on a 5-point Likert scale from "not a priority" to "essential" (Yin, 2013). Interviews were transcribed by a third party, reviewed for accuracy by the researcher, and coded independently by the researcher. Following coding, an experienced researcher checked the coding for reliability. Data were analyzed using an inductive approach (Gibbs, 2018; Goddard \& Melville, 2004; Patton, 2002). The researcher and second coder compared codes and established the intercoder agreement.

Gibbs (2018) and Neuendorf (2002) found that covering at least $10 \%$ of the data would suffice for a check for intercoder reliability if the agreement rate is $80 \%$ or higher. For consistency, the researcher and additional reviewer met briefly following the coding of each interview transcript. To ensure that the agreement rate reached $80 \%$, the researcher and coder assessed reliability informally during coder training with a small number of components separate from full sample and refined the coding instructions until the informal assessment suggested a satisfactory level of agreement (Gibbs, 2018; Lombard, Snyder-Duch, \& Bracken, 2002). The codes were organized into themes and developed into theme clusters, and theme categories. These categories were put into a codebook in Microsoft excel. Each category was color coded and defined by the researcher to clarify the meaning of each theme. The primary researcher refined and condensed the data under each theme before analysis. The researcher and second 
coder established underlying subthemes relevant to each emerging theme. These subthemes guided the researcher deeper into each element and established a basis for criteria viewed by the participant as important to program structure and sustainability.

\section{Results and Discussion}

Data results and discussion are divided into two focal segments. Several subthemes emerged from each focal segment. Therefore, for the purpose of this research, merging results and discussion lends itself to greater clarity for the reader.

Figure 1

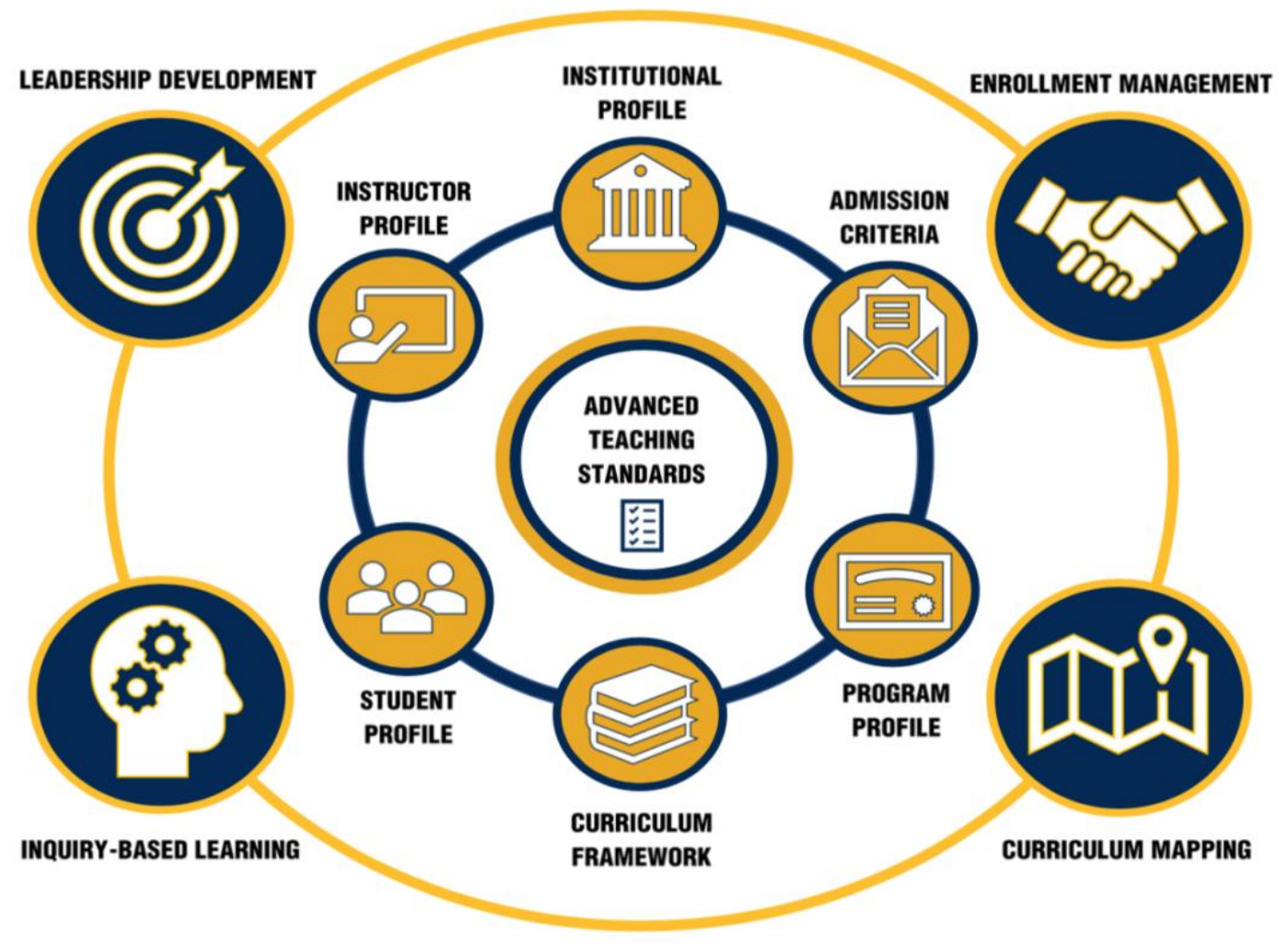

Figure 1 represents the structure of results and discussion. The inner circles in yellow depict the qualitative survey 
portion of the results. Curriculum Framework and Institutional Profile are predominant themes in the findings. Student Profile and Instructor Profile are subthemes under Institutional Profile. Program Profile and Admission Criteria are subthemes under Curriculum Framework. The outer circles in blue portray the four major themes taken from the semi-structured interview portion of the results.

\section{Survey}

Some items have a varying number of responses. The survey portion contained two focal categories of institutional profile and curriculum framework. Under these two focal categories, subcategories of instructor profile, student profile, admission criteria, and program profile emerged.

Institutional profile. The institutional profile includes student population, university Carnegie classification, private or public affiliation, geographic region, and developed environment (See Table1). The student population including on-campus and distance learning students were reported to range from 4,000-36,000 students. The overwhelming majority of participants reported a Carnegie classification of doctoral university (53.85\%) or masters granting college or university (38.46\%). PETE master's degree program were being offered at predominantly doctoral and masters granting universities. The majority of the respondents $(84.62 \%)$ indicated that their university offered a master's degree and a bachelor's degree in PETE, and approximately one-third $(30.77 \%)$ listed the availability of a doctoral degree in PETE in addition to the masters and bachelor's degrees. Of the 13 responses, PETE master's programs ranged from 30 to 39 credit hours $(M=31.48, S D=2.62)$

Eleven $(84.62 \%)$ of the participating universities were public, and the remaining two (15.38\%) identified as private. The southeast (30.77\%) and middle Atlantic (23.08\%) geographic regions comprised slightly over half of the useable data $(53.85 \%$ combined). Following this, the heartland and rocky mountain regions each made up $15.38 \%$ of usable data with the east-central and New England regions each making up 7.69\% of the data. Just over three quarters (76.92\%) 
of universities were located in either rural $(38.46 \%)$ or urban $(38.46 \%)$ settings. The remaining universities (23.08\%) reported a suburban location. Recent studies depicting geographical distribution of PETE programs in the United States may not exist. According to Boyce, Lund, and O’Neil (2015), approximately 96\% of institutions offering PETE doctoral degrees (23 total according to 2011-2012 data) also offer undergraduate PETE programs. Programs offering initial licensure in physical education totaled $96 \%$ according to $2011-2012$ data. Types of programs offering initial teacher licensure included undergraduate programs, standalone graduate programs, and 5-year programs. All but one PETE doctoral program contained some form of initial licensure (Boyce et. al, 2015). The previous findings lend themselves to the belief that if institutions offering initial licensure offer doctoral level PETE programs, that the master's programs may mirror these offerings.

Student profile. Over half of the respondents indicated their students were enrolled fulltime. Nine programs $(69.23 \%)$ indicated the availability of graduate assistantships to PETE master's degree-seeking students. Of the respondents reporting graduate assistantship availability, half (50\%) of those listed other duties as teaching physical education, teaching before and after-school programs, assisting with labs in schools, teaching physical education in a satellite school, and various instructional responsibilities as additional graduate assistant responses.

In a multi-response question, just over half (62.5\%) of respondents indicated teaching basic instruction courses as part of graduate assistant duties and responsibilities. Similarly, $62.5 \%$ of institutions stated that research was part of their graduate assistant duties. These findings show that though some PETE masters TCs are gaining valuable experience teaching K12 students as part of graduate assistantships, those performing other duties may lack the 
practical experience set forth as a measure for meeting advanced standard criteria. Furthermore, findings indicate that the vast majority are entering master's degree programs without initial licensure, further complicating meeting the requirements of the advanced standards, as advanced PETE Standards are used in the national recognition process to review advanced-level programs. Advanced level programs are defined as “master's degree, post-initial licensure” by SHAPE America (2015, p. 1). Furthermore, SHAPE America explicitly states that institutions offering master's degrees meant for initial licensure should use the initial "PETE Standards for national recognition review" (SHAPE America, 2015, p. 1). When the master's degree is offered in a broad field such as kinesiology, curriculum, or general education, the appropriateness of SHAPE America's advanced standards should receive careful consideration.

Instructor profile. Eleven participants responded with useable data in the instructor profile portion of the survey (See Table 2). The number of faculty delivering instruction in the participating PETE masters programs varied from a low of two individuals to a high of eight with a relatively even representation by gender across all programs. The majority of programs were taught by primarily Caucasian faculty of both genders, showing a lack of diversity by race/ethnicity across full-time faculty (92.7\% Caucasian, 5.5\% Asian). One program did indicate that one instructor fell into the race category of "other," but did not indicate that race in their reply. This echoes Ayers and Housner's (2008) and Taliaferro et. al (2017) findings of an overly representative population of Caucasian faculty in PETE (respondents reported employing a 92\% Caucasian faculty). However, the trend shows an increase in non-Caucasian faculty; $9 \%$ in 2005-2006 to 11\% in 2008-2009 and 15\% in 2011-2012 (Boyce \& Rikard, 2011; Boyce, Lund, \& O'Neil, 2015; Taliaferro et. al, 2017). While the trend suggests the number of non-Caucasian faculty in PETE is on the rise, it is important to continue this trend to reflect a more diverse 
faculty population. A more diverse faculty may prove beneficial to students studying in universities in diverse areas, and those students who prefer to work with a racially diverse population. According to Taliaferro et. al (2017), the need for a more diverse population of PETE faculty may be beneficial to reflect a teacher population that closely reflects the K-12 student population.

Most instructors had earned a doctoral degree, full-time teaching experience in the K-12 stetting. Findings showed considerable variation in the number of years teaching in the higher education setting. This finding shows that most or all faculty teaching courses in masters in PETE programs should hold a higher level of research experience and background knowledge within the discipline. Diversity in training and specialization of faculty may be viewed as a strength in structuring well rounded programs involving various subdisciplines of kinesiology. This would require intentional recruitment of underrepresented populations of students seeking physical education teacher certification. Areas of instructor specialization most prevalent included pedagogy, adapted sport/PE, and special education (See Table 3). Findings related to teacher educator acquired classroom experience proved important, as a common assumption is that a good teacher educator must have in field classroom experience (Korthagen, Loughran, \& Lunenberg, 2005).

Becoming a teacher of teachers should draw on, but should not be limited to, the knowledge and understanding accumulated through practice (Murray \& Male, 2005). In a 2014 study describing their current practices, many teacher educator interviewees reported falling back on their own experiences as classroom teachers to inform their work with preservice students (Godwin et. al, 2014). Goodwin et. al's (2014) findings also showed that teacher educators often feel unprepared in their role, but still offer valuable insight into methodical thinking about what 
represents a high-quality teacher education program.

Curriculum framework. Of the 13 participating programs, almost half $(n=6)$ utilized the cohort system, requiring students to progress through the program in a lock-step fashion. All 13 programs $(100 \%)$ are designed for coursework to be completed in the fall, spring and summer terms. The only curricular aspect applicable to all 13 (100\%) programs was a research requirement. Participating program affiliates did not indicate that a specific line of research was required.

Content threaded throughout courses included technology and its application to PE (instructional technology in PE and advanced labs), administration (leadership, coaching and athletic administration) research and statistics (statistical methods in education, scientific basis of health and physical education), teaching methods (principles of effective teaching and advanced lab, foundations of teaching), motor learning, special education (recreation for special populations, advanced motor learning), sport pedagogy (sport in American life, perspectives in sport pedagogy), coaching (sport facility planning and management, intercollegiate athletics in higher education), and health (stress management, health promotion). Specific themes or courses stranded in program coursework included adapted sport and PE, technology, and foundational knowledge. It is important to note that participants were able to select multiple course content offerings. Course content specific to curricular models, standards-based assessments, schoolbased physical activity, supervision, and hands-on experiences were incorporated less across programs (See Table 4). Based on instructors' areas of expertise (See Table 3), findings may lead to the conclusion that coursework in PETE master's programs appears to be aligned with expertise of faculty as opposed to being based on the advanced standards. Areas in which instructors were highly specialized such as special education and adapted physical education 
played a greater role in program coursework according to participants.

Admission criteria. Only 2 of 13 programs (15.4\%) required an initial teaching license in physical education or another discipline as a requirement for admission. The remainder of the programs resulted in initial teaching licensure. Three of the $13(23 \%)$ programs that reported no licensure requirement also stated that teaching licensure had been a requirement for admission in the past but has since been eliminated. This may be due to a rising need to maintain and increase program enrollment (Ayers \& Woods, 2019; Bulger, Braga, DiGiaicinto \& Jones, 2016). Of the 13 responding programs, the mean number of students attending full time was 52.69 and mean for part-time attendance was 47.31. This mean for full time attendance may be due to the availability of graduate assistantships which typically require full time attendance, in the majority of programs. Interestingly, full time attendance and lack of requirement for initial teaching licensure means that the masters TC is not currently a practicing PE teacher. SHAPE America explicitly outlines that its advanced standards are intended for post initial licensure, and those who are currently an active practitioner (SHAPE America, 2015). Though lack of current practice does not equate to lack of licensure, many programs have intentionally designed course assignments and schedules to benefit those currently teaching in the field.

In response to the option to elaborate on the elimination of teaching licensure as a requirement, one anonymous respondent indicated, "While this [teaching licensure] is preferred, we have adjusted our admission criteria to not require this [certification]. Although our program is not an initial certification program, we have added a post-baccalaureate track that allows students to earn certification through a combination of UG [undergraduate] and MS-level [masters level] coursework. Background in physical education, sport pedagogy, physical activity, and education is preferred, but not required." None of the program representatives indicated that 
previous teaching experience was a requirement for program admission. It should be noted that licensure and experience are separate. Licensure refers to the certification to teach upon completion of the requirements of a bachelor's degree teacher-training program. Experience refers to the act of teaching in the classroom or gymnasium setting. According to SHAPE America (2015), the advanced PETE standards are used in the national recognition process to review advanced-level programs. Institutions that offer a master's degree program designed for initial licensure or certification to teach should use SHAPE America's Initial PETE Standards for national recognition review (SHAPE America, 2015).

Program profile. Approximately one-third of respondents (36.3\%) indicated that their masters in PETE program was accredited on a national level (NCATE/CAEP/TEAC), 36.3\% indicated state level accreditation, with the remaining programs $(27.4 \%)$ not accredited on any level. The overwhelming majority $(90.91 \%)$ of respondents indicated familiarity with SHAPE America's advanced standards. It should be noted that familiarity on average, the length of time to complete the program varied from a minimum of 3 and a maximum of 6 semesters $(S D=4.92)$. In a multi-response question, $70 \%$ of respondents indicated that their program was based on state teaching standards, 40\% reported their program was based on SHAPE America's advanced teaching standards, and 20\% were based on SHAPE America's initial teaching standards. Each program participant was asked to rate the priority of the elements that composed each of the three advanced standards. A standard is considered met if all underlying elements are met (SHAPE America, 2015). For standards 1 (Professional Knowledge) and 2 (Professional Practice) participants rated the majority of the elements as high to essential prioritization in their PETE master's programs (see Tables 5 \& 6). One component of Professional Practice discusses reflection, and systematic inquiry about teaching and $63.6 \%$ of participants indicated high or 
essential prioritization of this element. Reflection and inquiry into planning, instruction, and assessment, are essential for continued teacher enhancement (Metzler, 2015). The results from the prioritization Likert scale and the theme of inquiry-based learning in the qualitative portion point to the fact that the master's degree programs participating in this research do prioritize and implement Professional Practice and inquiry into practice.

Standard 3 (Professional Leadership) is the only standard that dropped below the majority of high to essential prioritization (See Table 7). According to Wenner and Campbell (2017) and York-Barr and Duke (2004) the importance of teacher leadership in schools may be second only to classroom instruction. What constitutes a teacher leader remains widely diversified, as teacher leaders hold many titles, including a coach, mentor, and department chair (Wenner \& Campbell, 2017). According to the qualitative findings of this study, the Professional Leadership advanced standard, and the Role of Leadership guiding principle have been incorporated by program affiliates to help to diversify master's TCs role in and outside of the physical educator further supporting the importance of teacher leadership. The findings from the quantitative portion of this study indicate a lower prioritization than the qualitative portion. This finding lends itself to reexamine the role of teacher leadership in PETE master's degree programs. Interestingly, findings from this study indicated that advanced standards are not a foreign concept; programs are familiar with and incorporating principles of advanced standards but are not basing the entire program on these standards.

\section{Semi-Structured Interviews}

When four professors affiliated with PETE graduate programs were interviewed regarding their use of SHAPE America's guiding framework to inform the advanced standards, four relevant themes emerged. Themes of leadership development, curriculum mapping, 
inquiry-based learning, and enrollment management made up a majority of the discussion between interviewer and interviewees. Under each of the four themes, subthemes emerged. These subthemes will be outlined following each preceding larger theme. It should be noted that two of the four participants interviewed were affiliated with PETE master's programs requiring initial licensure for admission. The remaining two programs had no initial licensure requirement.

Leadership development. Developing teachers as leaders means that the teacher must assume a range of roles to support success within their profession and school. Leadership roles may be formal or informal, alone or shared, and facilitate school, field, and personal improvement. PE teachers and TCs have a responsibility to promote positive health behaviors and outcomes in schools (Goc Karp et al., 2017). Therefore, graduate expectations focus on developing the practitioner instead of creating effective novice teachers. Bulger, Illig and Jones (2017) echo these expectations by outlining three areas of leadership competencies specific to graduate level studies. The three areas, team building/facilitation, capacity building, and program development/management, differ from undergraduate level leadership competencies focusing on content knowledge and knowledge of instructional practice (Bulger et al., 2017).

Leadership and leadership advocacy for PETE masters TCs were common themes throughout the interviews. According to interview participants, K-12 student progress occurs after the teacher continues to progress and develop as a professional. Masters in PETE courses that intertwine leadership development and leadership initiatives in existing courses were a commonality among 3 out of 4 of interviewees. Participant three responded, "I am not sure that we do [focus on leadership].” Three subthemes of leadership strands, classroom leadership, and leadership outside teaching (administration, coaching, athletic director) emerged from the larger 
theme of leadership development. Representative quotations for leadership may be found in Table 8 .

Leadership Strands. Due to the overall rise in the national obesity epidemic, physical education teachers across the nation have been tasked as leaders of physical activity promotion through the use of a Comprehensive School Physical Activity Program (CSPAP) (Deuahnauer et al., 2017). Several recent studies (Bulger et al., 2017; Deuahnauer et al., 2017; Goc Karp et al., 2017; Sundaresan, Dashoush, \& Shangraw, 2017; Zhang, Gu, Zhang, Keller, \& Chan, 2018) described the importance of reforming PETE undergraduate and graduate plans of study to incorporate the knowledge, skills and proficiencies essential for a teacher leader CSPAP in K-12 schools.

Participant four indicated that one course in their curriculum "is going to focus on leadership and advocacy, and how physical educators can be intentional in how they matriculate through a career and develop as leaders." Participant two named leadership requirements for courses in the PETE master's curriculum ranging from sharing leadership-based projects "with their [PETE master's candidate's] school administrator, or their school board, alternatively, they could decide to take the initiative and share the outcomes of that project or take it to a greater extent onto their community or even state conference." The program of participant one offered an "assessment course meant for leadership." Meaningful assessment is quickly becoming a central part of K-12 physical education programs. In December 2015, the authorization of Every Student Succeeds Act (ESSA) identified physical education as a component of "well- rounded education," a term that has replaced "core academic subjects" (Wright, 2015). There is a need now, more than ever, for teacher leaders who create and implement well-rounded and meaningful pre and post formative, summative, and standards-based assessments covering the 
cognitive, psychomotor, and affective domains of learning (Sundaresan et al., 2017). The importance of teacher leadership and its relationship to high quality K-12 student assessment is echoed by participant one stating "you are [PETE masters students] taking data, evaluating it and making day to day decisions" based off of those outcomes. A second university offered a course focused on "guiding a group through curriculum development" and establishing deadlines, dates, and goals. These findings show that there is an awareness of the importance of leadership in PETE, and some masters programs have modified curriculum to meet this need.

Classroom leadership. According to Fairman and MacKenzie (2015) teachers have a responsibility to be a leader in both direct and indirect roles. Participant two stated that leadership focusing on the student (K-12) as a learner requires much "more of a leadership focus [for the teacher]." Programs have shifted from giving teachers the next set of skills to giving them [teachers] a strong focus on leadership in teaching to enhance teaching skills. The focus on the importance of leadership in teaching was a consensus among all interviewees. Participant four's emphasis of this leadership focus is “'on bettering oneself as a [master's degree] learner to impact your professional practice and what it is that you do on a day to day basis with your learners." According to Poekert, Alexandrou and Darbiann (2016), teacher leadership is increasingly presented as a useful answer to guide teacher learning, school improvement, and policy reform. Poekert et al. (2016) also noted that teacher leadership development is positioned in the framework of the classroom, the school, and the community. Each of these settings plays an integral part in developing a well-rounded teacher leader. Teaching teachers to lead in their classroom only is often not enough to create a well-rounded teacher leader. The third and final piece to the puzzle comes from leadership outside of teaching. 
Leadership outside of teaching. Due to broadening expectations placed on PE teachers, it has become essential for educator preparation programs to provide training for teachers to perform essential leadership functions inside and outside of instruction (Dauenhauer et al., 2017; Erwin, Beets, Centeio \& Morrow, 2014). Participant two’s vision of leadership outside of teaching means taking leadership skills to the next level and facilitating the teachers' desire to grow professionally and building "capacity [for leadership] within the spheres of influence, within their communities and beyond." Courses at participant one's university have been "designed for people who would take leadership roles [relevant to physical education] in special associations." Participant two more specifically stated that outside leadership may take shape in the form of becoming a national board-certified teacher, becoming a master teacher, and having teachers "think about their school and community stakeholders involved, their administrators, and look for ways that they could communicate the value of their physical activity and value of physical education outside of their classroom."

Bagley and Margolis (2018) referred to this as hybrid teacher leadership (HTL). HTL focuses on teaching K-12 students and becoming leaders outside of the classroom in some capacity, most notably through leading other teachers in the form of professional development and administration. Bagley and Margolis (2018) reinforced the critical roles of hybrid teacher leaders, listing career exploration outside of the classroom as a primary benefit of HTL. The authors defined career exploration as examining roles beyond teaching on a full-time basis. HTL ties directly to the findings of the leadership from this study, and the leadership focus of SHAPE America's advanced standards. It is imperative for PETE master's programs advance master teacher expectations further from that of undergraduates and include a strong leadership focus in the master's curriculum to develop the advanced TCs as teacher leaders. An additional focus for 
three interviewees was on building a plan to focus on how they [PETE masters TCs] can develop leadership across their career. The leadership development findings discussed in this section intertwine directly with the guiding principle of the roles of leadership. Note that the small sample size $(n=4)$ may show the prioritization of leadership in the questioned programs. The strong focus, however, may be widespread among PETE master's programs not interviewed for this research. Focusing on building higher capacity for leadership focus in the curriculum lends itself to the next critical topic in the interview findings, curriculum mapping.

Curriculum mapping. Curriculum alignment refers to a coherent well-organized curriculum intentionally created to facilitate learning aligned across courses and steps to program completion. Program structure refers to the home base of the master's program. Subthemes emerging under curriculum mapping were curricular structure (structure which curriculum is organized from start to finish), curricular themes (primary focus of curriculum, e.g., leadership, health science), and program diversification (diversifying the program to enhance marketability of PETE masters TCs). Table 9 includes representative quotations for curriculum mapping.

Curricular structure. PETE master's program curricular structure covered all course offering formats. All participating programs offered some online component, including a blended "unique advanced laboratory, follow up course" followed by a face-to-face laboratory setting within a designated time period. Participant three stated that they "don't see that [online program delivery] changing in the next five years." Online student enrollments increased for the 14th straight year in 2016-17, with more than $31 \%$ of all college students taking at least one distance education course — and all evidence suggests the uptick has continued (Bednar, 2018; Seaman, Allen, Seaman, \& Babson Survey Research, 2018). 
Each university brought forth their unique perspective on curricular structure and continued to expand their curriculum based on student needs. All interviewees stated different reasons their programs' unique curricular structure. Participant one's program did offer initial PE certification, stating that "we were getting many students who wanted initial certification." PETE specific coursework and requirements varied from program to program. Participant one’s program offered "gradual courses in education followed by 12-15 [credit] hours in physical education," while a second program offered a "master of arts in education with about 12-15 [credit] hours [in physical education]." Additionally, participant one stated that that her university offers a "fifth-year program that leads to a Master of Arts in education with a physical education component."

This change from training practicing teachers to offering initial certification in the PETE master's program may be viewed adversely. Students may enter the program with little to no knowledge of pedagogical processes, physical education principles or research, and basic terminology in education. However, in a positive light, training teachers for initial certification at a more advanced stage in their educational process may offer unique benefits. Students are familiar with the process of college coursework. The transition from undergraduate to graduate students may be smoother than that from secondary education to post-secondary (high school to university). Finally, students enrolled in a master's program may view the advanced degree in a more serious light than an undergraduate degree. While there is no magic formula to measure the concepts above discussed, this topic may be one for further investigation in the future.

Curricular themes. Curricular themes unique to each university emerged as a result of adherence to SHAPE advanced standards and student needs. Participant two's university “decided to go ahead and create this new master's program with the focus on leadership in 
education, and adult education," while participant one's university positioned themselves toward "the health science approach instead of just strictly physical education." Another new curricular theme from participant four included "interdisciplinary approach or multi-disciplinary approach."

The consensus among four interviewees was to design curriculum focused on creating exemplary master teachers. Participant three's curriculum “take(s) into consideration [taking] a look at an integrated body of knowledge that we think exemplifies the master teacher." For recent graduates, connecting professional preparation and the workforce can be a sizeable task (Ensign, Woods \& Hodges, 2017). In some instances, once enthusiastic career expectations conflict with the reality of the daily requirements placed on teachers (Ensign et al., 2017). Interestingly, over $40 \%$ of novice teachers exit the profession within the first five years (Perda, 2013). This significant fact can be linked to the importance of retaining practicing teachers past the first five-year mark and beyond. The induction years are a crucial time for developing teaching practices. It is important to introduce varying new experiences and aid in developing the functions of effective teaching. Positive professional development experiences are crucial at this juncture (Ensign et al., 2017). In addition to positive professional development experiences, many teacher educator interviewees reported utilizing their own experiences as classroom teachers to inform their work with preservice students. (Goodwin et al., 2014).

The previously mentioned positive professional development experience during the PETE master's program may be a link to retaining novice teachers past the first five-year mark and beyond. These positive experiences can be achieved in the master's program by offering masters level TCs the chance to expand and restructure their knowledge and areas of expertise, thus bringing relevant and useful new information into their K-12 curriculum. 
Program diversification. Program diversification is any means of diversifying the existing program to enhance the marketability of students. Participant one stated, "the market is so saturated and difficult to get a teaching job they want to diversify [to] get them [students] onboard with a master's degree in PETE and include for example an 8-10 credit adapted certification." Examples of program diversification present in this research included making program graduates marketable to teach on the college level, experience in grant writing, and pay boosts upon obtainment of the master's degree, while other programs have "developed different standards for students who have an interest in becoming an athletic director or school district administrator."

This aspect of curriculum mapping interestingly ties directly to the role of leadership and integrated knowledge base guiding principles, and the focus on leadership and professional practice advanced standards. Many of the previously mentioned opportunities that programs offer to diversify their curriculum are blended directly to leadership roles (athletic director, district administrator, grant writing). Moreover, professional knowledge stated that programs would integrate and apply the skills, knowledge, and dispositions acquired in both their initial and advanced preparation programs in the teaching and learning process. This is apparent in curriculum diversification and unique course offerings, which require students to put PETE master's knowledge obtained into practice in their teaching, and in areas requiring leadership focus in courses and teaching practice. Moreover, all interviewees stated that their programs were housed in Kinesiology-based departments or controlled by the College of Education.

Inquiry-based learning. Analysis of teaching and learning refers to helping pre-service and practicing PE teachers improve to their teaching skills through practice, analysis, and reflection. Data analysis can provide a picture of students' current knowledge, what they need to 
know, and what can be done to achieve learning goals (Maass \& Engeln, 2018). Analysis of student learning data can provide a picture of students' current knowledge, what they need to know, and what can be done to achieve learning goals. Maass and Engeln (2018) stated it is essential to provide high-quality inquiry-based learning in professional development on a large scale. High stakes performance assessments, such as edTPA (Teacher Performance Assessment), support this implementation of best practices and are quickly becoming consequential with teaching licensure in many states (Metzler, 2014). These performance assessments require teachers to show intentionality and reflection in planning, teaching, and assessing K-12 students.

The influences of inquiry-based learning may offer consistency in curricular structure and student learning requirements to create and refine dynamic practitioners. Relevant to PETE, this large-scale professional development may occur through master's level coursework. Greater understanding of how student engagement with genuine inquiry-based approaches is needed to aid in designing more meaningful experiences for students (K-12) in physical education (Enright \& O’Sullivan, 2012; Kretchmar, 2000), and for developing a curriculum to enhance physical education and experiences beyond the classroom (O'Connor, Jeanes, \& Alfrey, 2016).

Authentic inquiry-based learning can contribute to meaningful and engaging learning experiences. Extra support for teachers is needed, specifically, foundations of approaches to critical inquiry that augment knowledge relevant to topics identified by the learner, a focus on authentic assessment, and aligning these with inquiry-based learning classroom (O'Connor et al., 2016). Inquiry-based learning results from interviewees yielded subthemes of effective teaching, data-driven teaching effectiveness, and course assessments to reflect inquiry-based learning. Representative quotations for inquiry-based learning can be found in Table 10. 
Effective teaching. According to participant one, a principle "focus [is placed] on effective teaching techniques [because] little or no experience [took place] in [previous] teaching preparation." Participant one additionally cited program goals to "expose the students to as much as we [instructors] possibly can in a limited amount of time, in a limited number of courses to try to enhance the learning related to the field [PETE]."

Master's level PETE programs should focus on advanced training techniques for candidates. However, some master's programs are tasked with the duty of preparing candidates who have no teaching certification or experience. Participant three noted that "[we] do our best to bring them [students] up to speed and also introduce them to advanced methods of teaching physical education which we go into in broad depth." The expectation for master's PETE students' performance according to participant four is "much higher than it [expectation] is for the undergraduate students." One way that programs have ensured the production of effective teachers is through a rigorous focus on reflection and assessment. Participant one cited that "students coming in [to the program] [with] teaching experience - reflection concerning what is happening, what works, what doesn't work, the impact it has on the students and students' performance," and "are students learning [and] can you document this learning?"

The use of models-based instruction in physical education can be a valuable tool for rational instructional practices; however, models-based-practices should work in conjunction with a thoughtful and thorough PE program (Landi, Fitzpatrick \& McGlashan, 2016). Participant two cited the use of Models Based Instruction as a critical component that "is all about reflection." This instructor conveyed the importance of teaching in the field using a models-based approach to teaching followed by reflection for future changes in teaching 
practice, stating "then they [PETE masters TCs] reflect on parts that are going well and parts that aren't going well, and make adjustments."

Lastly, the focus shifts from the lesson planning that typically occurs during undergraduate coursework to effective teaching in graduate coursework. Participant four noted that "it [teaching] is more than the lesson plan, going in and teaching and walking away, [teaching requires an] assessment of what exactly happened in that lesson.” Assessment justification and reflective commentary is a critical part of high stakes performance measures that are rapidly becoming consequential with earned teacher certification in many states (Metzler, 2014).

Course assignments to reflect inquiry-based learning. This research concluded that critical program assignments centered on technology, assessment/reflection, action-based research, supervision, and culminating requirements for program completion. During technology coursework, participant four noted that "learners are asked to identify instructional problems that might be solved with an innovative tool and establish a plan for implementing that technology within a unit of instruction then evaluate the effectiveness of it using reflective writing and evaluating the student outcomes and teacher outcomes."

Additional course requirements embedded within PETE master's curricula took creating active practitioners through assessment and reflection into account. Examples cited by participant one included 'talks, discussion posts, reflective assignments built into each classes' work requires them [students] to think critically about their professional practice." Moreover, candidates are asked to reflect on their teaching practice. Participant two noted that "[masters] candidates are asked to reflect, whether it is on special topics, contemporary issues, or whether it is on particular examples [given in] coursework." Coursework specific to assessment took place 
in participant three's program and utilized a broad-spectrum approach in general education. Participant three stated "I try to read widely in regular education, so it is not driven down to just physical education." The purpose of supervision coursework in participant two's program is for "[students to] learn how to observe and watch teaching and giving feedback. So, the emphasis is on promoting student learning."

An action-based research component was unique to one university. Initially designed for social issues and employed in 1946 by K. Lewin, action-based research is a valuable method for executing change through planning, acting, observing, and reflecting (Keegan, 2016). Keegan's (2016) research found that action research was effective in helping PE teachers enhance student (K-12) learning. The action-based research component discussed by participant four manifested itself as a project requiring the examination of the context "in which they [PETE masters TCs] are in and then be reflective about it," focusing on the question of "is there a particular problem that they may be focusing on to improve." Participant four also noted that "we [faculty/instructors] wanted to bring that [action research] back in [to the program]." Overall, participant four outlined the purpose of action-based research on a larger scale was to "take [findings] back to their schools, or community setting, and do action research type of project where they [PETE masters TCs] identify a problem, come up with a plan for implementation, and then evaluate the effectiveness of that plan." Keegan's (2016) research found that action research was effective in helping PE teachers enhance student (K-12) learning.

Finally, formally organized culminating requirements were an essential part of inquirybased learning in PETE master's programs. Culminating requirements included in participant two's program were "a comprehensive exam with us in physical education before they graduate," “emphasis on learning and learners because it does challenge the student or the professional 
learner to think about what practices they can improve upon in themselves (participant four)" and lastly, research requirements in the form of a master's thesis.

Data driven teaching effectiveness through evidence-based practice. Data-driven teaching effectiveness through evidence-based practice played a significant role in the findings centered on inquiry-based learning. Evidence of effectiveness in participant two's program was collected by "allowing teachers to provide video documentation... opens the doors for a lot of new possibilities in teacher education" through video analysis, and supervision coursework where students "[acquire] the training and be able to get the data-driven observation." Since video documentation is becoming a critical component of initial certification through high stakes performance assessment (Metzler, 2014), it is important that those programs offering initial certification in the PETE master's program prepare students to analyze video documentation of teaching to refine their practice. Also, field systems analysis (FSA) can be used separately for quantitative evidence of teachers' strengths and areas in need of improvement (Davis \& Hawkins, 2014).

Participant two's initial goal of video documentation was to make candidates aware of "formal and informal assessments, discipline, management, and leadership." The findings from the video documentation showcased students' ability to identify and display "interesting growth" within themselves "because of those assignments [video analysis]." Two of four respondents indicated assessment and evaluation related courses within their PETE master's program. These assessment courses take a "data-driven approach...to teach people how to do assessments; how do you assess your students and documenting student learning”. Participant four's assessment course focused on the use of assessment data in student evaluation and the "second part of the course focused on how you use the data; so, thinking about the kinds of information and the 
different types of assessments will leave you and reflecting on the data." Using data to improve teaching allows teachers inform their instruction, ultimately producing more effective practitioners. Participant four noted that "teachers that are in the field [are] looking at data points [and] then making decisions and speculating, diagnosing and prescribing what might be next steps."

The inquiry-based learning findings in this research tie directly into the guiding principle of the importance of inquiry and to the advanced standard of professional knowledge. Shulman (2004c) stated that PETE masters TCs are expected to examine their practice methodically and formally, utilizing reflection to refine practice and ultimately portray the expectations of a master educator. If teaching quality is expected to continue development, an inquiry into practice is essential for educators. Linking directly into the professional knowledge advanced standard, the expectation is that TCs find fresh and meaningful ways to use and build on existing knowledge (Rink, French, Lee \& Solomon, 1994) to gain an understanding of the application of knowledge into teaching. The previously mentioned course requirements and culminating pieces link inextricably into the professional knowledge advanced standard.

Enrollment management. Enrollment management includes student recruitment and retention. Recruitment looks at the long and short term and is built on relationships with TCs. Retention occurs when TCs remain throughout graduation. Programs also stated features unique to their program are used as a marketing tool to recruit new students. These combine to form the broad category of enrollment management. Subsections defined under the enrollment management are recruitment and unique features for recruitment. Representative quotations for enrollment management are outlined in Table 11. 
Recruitment. All interviewees stated that their universities were deliberate about recruiting students. Participant four stated that "[We are] intentional about providing promotional information to prospective students through a very targeted and automated system; [We are] working with academic affairs and various online communication platforms for students inquiring about programs.” Programs’ recruitment efforts focused on incentivizing for enrollment through signature features unique to the program, outside tools available for recruitment, and the challenges faced in student enrollment.

Examples of incentivizing for recruitment include an incentive for student referral, accelerated bachelors to masters programs, blended programs, and course offerings for nondegree seeking students. Participant four noted that "[those] who refer somebody to the program, and they actually apply, then there will be some incentive for that person too." Participant three's program offers an "accelerated bachelors to master's program, assisting bachelors and PETE students in their junior semester." Participant four also noted the importance of their "free webinars that might allow them [students] if they were to register and take some of the segments and chunks of our content that would allow them to work towards a degree in a little bit more self-paced manner."

Moving programs toward the online format presented itself as a recruiting tool utilizing distance learning to appeal to the busy practicing educator. Participant two cited that their program is "transitioning solely online from an economic standpoint [and the] university sees that to be a stronger recruiting tool; when it comes to master's programs distance learning, people from all around the world can be able to take teacher certification courses from anywhere." The consensus among participants was that more online [PETE] programs pop up as a way to incentivize the PETE master's program for students considering an advanced degree. 
At present, countless students access online educational resources with the use of mobile devices, often substituting this for traditional learning interactions (Anshari, Alas, Sabtu \& Hamid, 2016). Using online learning has aided professors in increasing efficiency and teaching effectiveness (Park \& Lim, 2015; Puzziferro \& Shelton, 2014). Over the past two decades, online education has quickly grown (Allen \& Seaman, 2015). According to the U.S. Department of Education (2013), the number of American college students taking an online course is $32 \%$, and those enrolled in a fully online program is $25 \%$ (Berry, 2018). Expanding and fine-tuning this online focus in PETE master's program is critical in recruiting and retaining students. According to Berry (2018), Zimmerman and Nimon (2017), and Ke and Hoadley (2009), graduate students who feel connected to peers and faculty have a higher likelihood of engaging academics and are less likely to withdraw from the academic program. These findings greatly impact PETE graduate programs, as all program affiliates surveyed indicated at least some online and distance component in their programs.

Unique recruitment features. Interviewees stated that the unique features of their PETE master's programs were fundamental in recruiting prospective students. Participant one noted unique feature of "meetings and hands-on; [I] have people come to my office, sit down, and show me exactly what the program looks like. [Our] strategy is to give that personal touch to students [to let the know that] we have a place for them. [I] personalize as much as I can.” Participant two' uses 'that [leadership] in some of the recruitment and marketing materials that program graduates go for." Lastly, participant four reiterated the importance of "growing [their program] into a neat mentor-mentee opportunity for the professional learning community to grow in that way we help to attract student with the summer bachelors' program". 
Specific recruitment initiatives mentioned by participant four included "looking for ways to connect with Academic Innovation or online tools to help us build some of those professional development credits for teachers in the state and surrounding states", striving to appeal to students outside of the traditional market, and online education. Enrollment management quickly presented itself as a component in need of attention and expression in PETE master's degree programs. Online and blended course offerings may be the beginning to one solution to continued interest and enrollment. The role of leadership guiding principle presented itself yet again relative to enrollment management. The role of leadership was mentioned by participant four noting the "importance of building a mentor/mentee component into their PETE master's program.”

Additionally, current students are expected to express themselves as leaders in the field by conveying what they have learned during master's coursework to fellow PE teachers and administrators through course projects and action research projects. The qualities mentioned above tie directly to the role of leadership and the focus on learning rather than teaching guiding principles by requiring students to showcase and apply their findings in real-world teaching situations. Finally, the findings in enrollment management tie directly to the advanced standards of professional leadership and professional practice.

\section{Limitations and Future Directions}

Between 11 and13 affiliates of PETE master's programs in the United States completed the survey portion of this research. Results may not apply to other existing PETE master's programs within the US. Additionally, the evaluation of qualitative data summarizes findings from 4 out of 13 responding universities offering a master's degree in PETE, further narrowing external validity. Some programs indicated the availability of initial certification, creating a need to 
incorporate SHAPE America's initial standards in master's degree programs instead of using the advanced standards. Programs offering a master's degree in PETE should continue to focus on meaningful incorporation the advanced standards, guiding principles, and utilize initial standards for initial licensure only. Programs should strive to continue and refine the Role of Leadership standard focus to relate explicitly to serving as a PE teacher leader. Though not all programs offered a leadership-specific track, all agreed on the importance of incorporating leadership initiatives for the master teacher. This component should continue to evolve with the PETE master's curriculum.

Data-driven teaching effectiveness through evidence-based practice presented itself as integral to producing advanced physical education teachers. Data-driven effective teaching is imperative in master's programs as more states continue to tie objective teacher assessment through edTPA, National Board Certification, and other subject-specific, performance-based assessments. Many programs are taking on a significant online/blended format to meet the needs of an ever-changing student population, indicating a need to align standard and objectives that may be met via distance learning. Online education is quickly becoming prevalent in US colleges and universities. The task of PETE master's professors and curriculum planners should be to seek out meaningful ways of incorporating SHAPE America's advanced standards, guiding principles, and initial standards (as necessary) to facilitate online learning relevant to teaching physical education in the K-12 setting. Enrollment management quickly manifested as a popular theme among interviewees. This recruitment and retention focus resulted in programs offering initial certification to candidates and admitting candidates without teacher certification and tied directly to the lack of adherence to SHAPE America's advanced standards. Additionally, a full to partial online component to PETE master's degree programs is quickly becoming widespread 
from an enrollment management standpoint. Based on participant feedback, this online trend is a component that will continue to grow with time. Enrollment management will continue to be a principal focus of programs as they strive to create master physical education teachers.

\section{Conclusion}

In summary, some PETE master's programs participating in this research have not been designed intentionally around SHAPE America's advanced standards. The majority of programs do align with and utilize aspects of SHAPE America's advanced standards into curriculum design. None of the programs required teaching experience for enrollment, while some required initial teacher certification in PE or another discipline. Some programs that did not require certification for admission did offer initial certification as part of their master's degree program. This lack of requirement for teacher certification means that masters' level programs offering initial certification should base their curriculum on SHAPE America's initial teaching standards (SHAPE America, 2015), as initial stands are meant for programs training effective novice teachers. SHAPE America's advanced standards were designed with the licensed practitioner in mind, are intended for master's TCs possessing the knowledge, skills, and dispositions of a licensed educator (SHAPE America, 2015).

Lastly, the focus on leadership was predominant in many programs. This leadership focus, while tying directly to the advanced standard of Focus on Leadership, was utilized from an enrollment management standpoint. Programs offering leadership opportunities and initiatives beyond initial certification such as health science, adapted, or administrative cognate or certification, PETE master's programs incentivize candidates to complete their curriculum to enhance marketability upon graduation. The focus on enrollment management, though not a question posed to interviewees, presented itself as a vital portion of the findings. Enrollment 
management is the backbone of sustainability and advancement for programs and should continue to be an important focal point for institutions and instructors (Bulger et. al, 2016). Essential to program sustainability and success is the need to recruit students outside of typical demographic areas (outside of state/region). 


\section{References}

Allen, I. E., \& Seaman, C. A. (2007). Likert scales and data analyses. Quality progress, 40(7), 64-65.

Anshari, M., Alas, Y., Sabtu, N. P. H., \& Hamid, M. S. A. (2016). Online Learning: Trends, issues and challenges in the Big Data Era. Journal of e-Learning and Knowledge Society, 12(1).

Arum, R., \& Roksa, J. (2011). Academically adrift: Limited learning on college campuses. Chicago, IL: University of Chicago Press.

Ary, D., Jacobs, L., Sorensen, C., \& Walker, D. (2013). Introduction to research in education: Boston: Cengage Learning.

Ayers, S.F., \& Woods, A.M. (2019). Chapter 5: Recruitment in PETE: Survey results and discussion. Journal of Teaching in Physical Education, 28(1), 37-44.

Ayers, S. F., \& Housner, L. D. (2008). A descriptive analysis of undergraduate PETE programs. Journal of Teaching in Physical Education, 27(1), 51.

Bagley, S. S., \& Margolis, J. (2018). The emergence and failure to launch of hybrid teacher leadership. International Journal of Teacher Leadership, 9(1), 33-46.

Bednar, J. (2018). Screen test: Why is online learning seeing a surge in popularity? Businesswest, 34(26), 32 .

Berliner, D. C. (1994). Expertise: The wonder of exemplary performances. In J. Mangieri \& C. Block (Eds.), Creating powerful thinking in teachers and students: Diverse perspectives. Fort Worth, TX: Harcourt Brace.

Berry, S. (2018). Building community in an online graduate program: Exploring the role of an in-person orientation. The Qualitative Report, 23(7), 1673-1687. 
Boyce, B.A., \& Rikard, G.L. (2011). Characteristics of PETE doctoral level institutions: Descriptions of programs, faculty, and doctoral students. Journal of Teaching in Physical Education. 30(2), 103-115.

Boyce, B. A., Lund, J., \& O'Neil, K. (2015). PETE doctoral institutions: Programs, faculty, and doctoral students. Research Quarterly for Exercise \& Sport, 86(3), 311-318.

Bulger, S., Illig, K., \& Jones, E. (2017). Achieving alignment in the preparation of CSPAP leaders in PETE programs. Journal of Physical Education, Recreation \& Dance, 88(2), $37-42$.

Clark, C. M., \& Peterson, P. L. (1986). Teachers' thought processes. In M. C. Wittrock (Ed.), Handbook of research on teaching (pp 3-129). New York: Macmillan.

Danielson, C. (2006). Teacher leadership that strengthens professional practice. Alexandria, VA: ASCD.

Darling-Hammond, L. (2008). Powerful teacher education: Lessons from exemplary programs. New York: John Wiley \& Sons.

Dauenhauer, B., Krause, J., Douglas, S., Smith, M., \& Stellino, M.B. (2017). A newly revised master's degree in physical education and physical activity leadership at the University of Northern Colorado. Journal of Physical Education, Recreation \& Dance, 88(2), 14-19.

Dauenhauer, B., Krause, J., Douglas, S., Smith, M., Babkes Stellino, M., \& Carson, R. L. (2015). Development of a master's program related to CSPAP leadership: Perspectives from UNC. Session presented at the Health and Physical Education Teacher Education Conference, Atlanta, GA. 
Davis, W. J., \& Hawkins, A. (2014). An exploration of master's degree field study and teacher and student behavior in physical education. Global Journal of Health \& Physical Education Pedagogy, 3(3), 179-200.

Denscombe, M. (2014). The good research guide: for small-scale social research projects. United Kingdom: McGraw-Hill Education.

Author, A. A. (Year of publication). Title of work: Capital letter also for subtitle. Location: Publisher.

Dillman, D. A., Smyth, J. D., \& Christian, L. M. (2009). Mail and internet surveys: The tailored design method (3rd ed.). New York: John Wiley and Sons.

Dillman, D. A. (2011). Mail and Internet surveys: The tailored design method--2007 Update with new Internet, visual, and mixed-mode guide. New York: John Wiley \& Sons.

Enright, E. \& O'Sullivan, M. (2012). Physical education in all sorts of corners: Student activists transgressing formal physical education curricular boundaries. Research Quarterly for Exercise and Sport. 83(2): 255-267.

Ensign, J., Woods, A.M., \& Hodges, K.P. (2017). Teacher development in first year physical educators: A comparison of effectiveness among different physical education teacher education backgrounds. Journal of Teaching in Physical Education, 36(4), 455-466.

Erwin, H., Beets, M. W., Centeio, E., \& Morrow Jr, J. R. (2014). Best practices and recommendations for increasing physical activity in youth. Journal of Physical Education, Recreation and Dance, 85(7), 27-34.

Fairman, J. \& Mackenzie, S. (2015). How teacher leaders influence others and understand their leadership. International Journal of Leadership in Education, 18(1), 61-87.

Gibbs, G. R. (2018). Analyzing qualitative data (Vol. 6). Newbury Park, CA: Sage. 
Goc Karp, G., Brown, H., Scrugges, P.W., \& Berei, C. (2017). Cultivating leadership, pedagogy and programming for CSPAP and healthy, active lifestyles at the university of Idaho. Journal of Physical Education, Recreation \& Dance, 88(1), 29-35.

Goddard, W., \& Melville, S. (2004) "Research methodology: An introduction" 2nd edition, Hoboken, NJ: Blackwell Publishing.

Goodwin, A. L., Smith, L., Souto-Manning, M., Cheruvu, R., Tan, M. Y., Reed, R., \& Taveras, L. (2014). What should teacher educators know and be able to do? Perspectives from practicing teacher educators. Journal of Teacher Education, 65(4), 284-302.

Hargreaves, A., \& Fink, D. (2006). Sustainable leadership (Vol. 6). New York: John Wiley \& Sons.

Hetland, K. M., \& Strand, B. (2010). A descriptive analysis of undergraduate PETE programs in the central district. ICHPER-SD Journal of Research, 5(1), 3-9.

Hooper, T., \& Butler, J. (2013). Complexity thinking in physical education: Reframing curriculum, pedagogy, and research. London: Routledge.

Horng-Yi, L. (2014). Inquiry-based teaching in second and foreign language pedagogy. Journal of Language Teaching \& Research, 5(6), 1236-1244.

Huba, M. E., \& Freed, J. E. (2000). Learner centered assessment on college campuses: Shifting the focus from teaching to learning. Community College Journal of Research and Practice, 24(9), 759-766.

Hooper, T., \& Butler, J. (2013). Complexity thinking in physical education: Reframing curriculum, pedagogy, and research. London: Routledge.

Ke, F., \& Hoadley, C. (2009). Evaluating online learning communities. Educational Technology Research and Development, 57(4), 487-510. 
Keegan, R. (2016). Action research as an agent for enhancing teaching and learning in physical education: A physical education teacher's perspective. The Physical Educator, 73(2), 255-284.

Korthagen, K., Loughran, J., \& Lunenberg, M. (2005). Teaching teachers-Studies into the expertise of teacher educators: An introduction to this theme issue. Teaching and Teacher Education, 21, 107-115.

Kretchmar, R. (2000). Movement subcultures: Sites for meaning. Journal of Physical Education Recreation \& Dance, 71(5): 19-25.

Landi, D., Fitzpatrick, K., \& McGlashan, H. (2016). Models based practices in physical education: A sociocritical reflection. Journal of Teaching in Physical Education, 35(4), 400.

Lewin, K. (1946). Action research and minority problems. Journal of Social Issues, 2(4), 34-46.

Lombard, M., Snyder-Duch, J., \& Bracken, C. C. (2002). Content analysis in mass communication: Assessment and reporting of intercoder reliability. Human Communication Research, 28(4), 587-604.

Maass, K., \& Engeln, K. (2018). Effects of scaled-up professional development courses about inquiry-based learning on teachers. Journal of Education and Training Studies, 6(4), 116.

Mawer, M. (2014). Effective teaching of physical education. London: Routledge.

Metzler, M.W. (2014). Teacher effectiveness research in physical education: The future isn't what it used to be. Research Quarterly for Exercise and Sport, 85(1), 14-19.

Nappi, J. S. (2014). The teacher leader: improving schools by building social capital through shared leadership. Principal's Research Review, 9(6), 1-6. 
National Association for Sport and Physical Education. (2008). PE Metrics: Assessing the national standards. Reston, VA.

National Association for Sport and Physical Education. (2009). National Standards and Guidelines for Physical Education Teacher Education (3rd ed.). Reston, VA.

Neuendorf, K.A., 2002. The content analysis guidebook. Thousand Oaks, CA: Sage.

O'Connor, J., Jeanes, R., \& Alfrey, L. (2016). Authentic inquiry-based learning in health and physical education: A case study of revolutionary practice. Physical Education \& Sport Pedagogy, 21(2), 201-216.

Ott, M., Baca, E., Cisneros, J., \& Bates, E. (2015). A competency-based approach to the master's degree preparation of higher education professionals. Journal of Case Studies in Accreditation and Assessment, 4, 1 .

Park, Y., \& Lim, K. (2015), Effects of environmental and human constructs on e-learning effectiveness in online university settings. Indian Journal of Science and Technology, 8(S1), 103-109.

Patton, M. (2002). Qualitative evaluation and research methods. Thousand Oaks, CA: Sage.

Perda, D. (2013). Transitions into and out of teaching: A longitudinal analysis of early career teacher turnover (Unpublished doctoral dissertation). University of Pennsylvania, Philadelphia.

Petrie, K., \& McGee, C. (2012). Teacher professional development: Who was the learner? Australian Journal of Teacher Education, 37(2), 59-72. 
Poekert, P., Alexandrou, A., \& Shannon, D. (2016). How teachers become leaders: An internationally validated theoretical model of teacher leadership development. Research in Post-Compulsory Education, 21(4), 307-329.

Puzziferro, M., \& Shelton, K. (2014), A model for developing high-quality online courses: Integrating a systems approach with learning theory. Journal of Asynchronous Learning Networks, 12, 119-136.

Ramsey, C., Hawkins, A., Housner, L., Wiegand, R., \& Bulger, S. (2009). Finding the recipe for the best blend: The evolution and assessment of a blended master's degree program. Journal of the Research Center for Educational Technology, 5(2), 3.

Richards, K.A.R., Gaudreault, K.L., Simonton, K.L., \& Simonton, A. (2018). Physical education graduate student socialization in a research-focused master's program. Journal of Teaching in Physical Education, 37(4), 373-382.

Rink, J. E., French, K. E., Lee, A. M., Solomon, M. A., \& Lynn, S. K. (1994). A comparison of pedagogical knowledge structures of preservice students and teacher educators in two institutions. Journal of Teaching in Physical Education, 13(2), 140.

Seaman, J. E., Allen, I. E., Seaman, J., \& Babson Survey Research, G. (2018). Grade increase: Tracking distance education in the United States. Forest Park, MA: Babson Survey Research Group.

Shulman, L. (2004c). Disciplines of inquiry in education. In L. Shulman \& S. M. Wilson (Eds.), The wisdom of practice: Essays on teaching, learning and learning to teach (276-307). San Francisco: Jossey-Bass.

Shulman, L. (2013). Those who understand: knowledge growth in teaching. Journal of Education, 193(3), 1-11. 
Society of Health and Physical Educators (SHAPE America). (2015). Retrieved September 20, 2015, from http://www.americankinesiology.org/affiliated-associations/affiliatedassociations/national-association-of-sport-and-physical-education-naspe

Stein, L. (2014). Leadership: The teacher's imperative. Journal of Leadership Education, 13(2), 162-168.

Sundaresan, N., Dashoush, N., \& Shangraw, R. (2017). Now that we're “well rounded," let's commit to quality physical education assessment. Journal of Physical Education, Recreation \& Dance, 88(8), 35-38.

U. S. Department of Education. (2013). The condition of education 2011 Table A-43-1. Washington, DC: National Center for Education Statistics.

Wenner, J. A., \& Campbell, T. (2017). The theoretical and empirical basis of teacher leadership: A review of the literature. Review of Educational Research, 87(1), 134-171.

Wiegand, R. L., Bulger, S. M., \& Mohr, D. J. (2004). Curricular issues in physical education teacher education. Journal of Physical Education, Recreation \& Dance, 75(8), 47-55.

Yin, R. K. (2013). Case study research: Design and methods. Washington D.C.: Sage.

York-Barr, J., \& Duke, K. (2004). What do we know about teacher leadership? Findings from two decades of scholarship. Review of Educational Research, 74(3), 255-316.

Zhang, Z., Gu, X., Zhang, T., Keller, J., \& Chan, S. (2018). Comprehensive school physical activity programs: Recommendations for physical education teacher education. Journal of Physical Education, Recreation \& Dance, 89(5), 11-18.

Zimmerman, T., \& Nimon, K. (2017). The online student connectedness survey: Evidence of initial construct validity. International Review of Research in Open and Distributed Learning, 18(3), 25-46. 
Table 1 Institutional Profile; Classifications, Student Population, Demographics (N=13)

\begin{tabular}{llllll}
\hline Institution & $\begin{array}{l}\text { Student } \\
\text { Population }\end{array}$ & $\begin{array}{l}\text { Carnegie } \\
\text { Classification }\end{array}$ & Private/Public & $\begin{array}{l}\text { Geographic } \\
\text { Region }\end{array}$ & $\begin{array}{l}\text { Developed } \\
\text { Environment }\end{array}$ \\
\hline 1 & 28,776 & Doctoral & Public & East Central & Rural \\
2 & 36,000 & Doctoral & Public & Heartland & Rural \\
3 & 8,300 & Master's & Public & Southeast & Urban \\
4 & 15,000 & Doctoral & Public & Mid Atlantic & Rural \\
5 & 4,462 & Master's & Private & Mid Atlantic & Urban \\
6 & 6,500 & Master's & Public & New England & Suburban \\
7 & 10,000 & Doctoral & Public & Southeast & Rural \\
8 & 14,551 & Doctoral & Public & Southeast & Suburban \\
9 & 7,500 & Baccalaureate & Public & Heartland & Rural \\
10 & 12,000 & Doctoral & Public & Rocky Mountain & Suburban \\
11 & 4,000 & Master's & Private & Mid Atlantic & Suburban \\
12 & 32,000 & Doctoral & Public & Rocky Mountain & Urban \\
13 & 7,300 & Master's & Public & Southeast & Urban \\
\hline
\end{tabular}


Table 2

Instructor Profile; Race, Gender, Status, Higher Education Credentials (N=11)

\begin{tabular}{|c|c|c|c|c|c|c|c|c|c|c|c|}
\hline Institution & 1 & 2 & 3 & 4 & 5 & 6 & 7 & 8 & 9 & 10 & 11 \\
\hline $\begin{array}{l}\text { Number of } \\
\text { Instructors }\end{array}$ & 6 & 5 & 3 & 3 & 8 & 5 & 6 & 5 & 3 & 2 & 5 \\
\hline \multicolumn{12}{|l|}{ Gender } \\
\hline Male & $67 \%$ & $20 \%$ & & $67 \%$ & $37.5 \%$ & $80 \%$ & $67 \%$ & $60 \%$ & $67 \%$ & $50 \%$ & $67 \%$ \\
\hline Female & $33 \%$ & $80 \%$ & $100 \%$ & $33 \%$ & $62.5 \%$ & $20 \%$ & $33 \%$ & $40 \%$ & $33 \%$ & $50 \%$ & $33 \%$ \\
\hline \multicolumn{12}{|l|}{ Race } \\
\hline Caucasian & $100 \%$ & $80 \%$ & $100 \%$ & $100 \%$ & $100 \%$ & $60 \%$ & $100 \%$ & $100 \%$ & $100 \%$ & $100 \%$ & $80 \%$ \\
\hline Asian & & $20 \%$ & & & & $20 \%$ & & & & & $20 \%$ \\
\hline Other & & & & & & $20 \%$ & & & & & \\
\hline \multicolumn{12}{|c|}{ Faculty Status } \\
\hline Full-Time & $83 \%$ & $80 \%$ & $100 \%$ & $100 \%$ & $75 \%$ & $100 \%$ & $83 \%$ & $100 \%$ & $100 \%$ & $100 \%$ & $100 \%$ \\
\hline Part-Time & $17 \%$ & $20 \%$ & & & $25 \%$ & & $17 \%$ & & & & \\
\hline \multicolumn{12}{|c|}{ Highest Degree } \\
\hline \multicolumn{12}{|l|}{ Earned } \\
\hline Doctorate & $83 \%$ & $40 \%$ & $100 \%$ & $100 \%$ & $87.5 \%$ & $100 \%$ & $100 \%$ & $100 \%$ & $100 \%$ & $100 \%$ & $100 \%$ \\
\hline Master’s & $17 \%$ & $40 \%$ & & & $12.5 \%$ & & & & & & \\
\hline Bachelor's & & $20 \%$ & & & & & & & & & \\
\hline \multirow{2}{*}{\multicolumn{12}{|c|}{$\begin{array}{l}\text { K-12 Teaching } \\
\text { Experience (Full }\end{array}$}} \\
\hline & & & & & & & & & & & \\
\hline \multicolumn{12}{|l|}{ Time) } \\
\hline Yes & $67 \%$ & $80 \%$ & $67 \%$ & $67 \%$ & $25 \%$ & $100 \%$ & $67 \%$ & $80 \%$ & $100 \%$ & $100 \%$ & $40 \%$ \\
\hline No & $33 \%$ & $20 \%$ & $33 \%$ & $33 \%$ & $75 \%$ & & $33 \%$ & $20 \%$ & & & $60 \%$ \\
\hline \multicolumn{12}{|c|}{$\begin{array}{l}\text { Years Teaching in } \\
\text { Higher Education }\end{array}$} \\
\hline Mean & 7.5 & 9.4 & 13 & 9 & 15.4 & 10.2 & 10.5 & & 12.6 & 21 & 17 \\
\hline Range & 14 & 10 & 14 & 8 & 25 & 31 & 17 & & 18 & 18 & 39 \\
\hline
\end{tabular}


Table 3

Area of Specialization for Instructors Teaching in PETE Master's Programs

Note: Participants may choose more than one option $(N=11)$

\begin{tabular}{llllllllllll}
\hline Institution & 1 & 2 & 3 & 4 & 5 & 6 & 7 & 8 & 9 & 10 & 11 \\
\hline Pedagogy & & & & N/A & & & & & & & \\
Adapted Sport/PE & & & & & & & & & & & \\
Special Education & $\mathrm{X}$ & $\mathrm{X}$ & $\mathrm{X}$ & & & & $\mathrm{X}$ & $\mathrm{X}$ & & $\mathrm{X}$ & $\mathrm{X}$ \\
Sport Psychology & $\mathrm{X}$ & $\mathrm{X}$ & $\mathrm{X}$ & & & $\mathrm{X}$ & & $\mathrm{X}$ & $\mathrm{X}$ & $\mathrm{X}$ & $\mathrm{X}$ \\
Other & $\mathrm{X}$ & $\mathrm{X}$ & $\mathrm{X}$ & & & $\mathrm{X}$ & & $\mathrm{X}$ & & $\mathrm{X}$ & $\mathrm{X}$ \\
Foundations of & & $\mathrm{X}$ & & & $\mathrm{X}$ & $\mathrm{X}$ & & & $\mathrm{X}$ & & \\
Education & & & & & $\mathrm{X}$ & & $\mathrm{X}$ & & $\mathrm{X}$ & & $\mathrm{X}$ \\
Exercise Science & & & & $\mathrm{X}$ & & & & & & \\
Curriculum & & & & & $\mathrm{X}$ & & & & & & \\
\hline
\end{tabular}

Table 4

Concepts Threaded Throughout PETE Master's Coursework

Note: Participants may choose more than one option $(N=13)$

\begin{tabular}{ll}
\hline Coursework Themes & Institutions \\
\hline Adapted Sport and PE & $81.82 \%$ \\
Foundational Knowledge & $81.82 \%$ \\
Technology in PE & $72.73 \%$ \\
Field Experiences & $63.62 \%$ \\
Multiculturalism and Diversity & $45.45 \%$ \\
Hands on Practicum & $36.36 \%$ \\
Instructional Models & $36.36 \%$ \\
Curricular Models & $36.36 \%$ \\
School Based Physical Activity & $36.36 \%$ \\
Standards Based Assessments & $36.36 \%$ \\
Supervision & $36.36 \%$ \\
\hline
\end{tabular}


Table 5

Prioritization of Standard 1; Professional Knowledge in PETE Master's Programs (N=11)

\begin{tabular}{llllll}
\hline & $\begin{array}{l}\text { Not a } \\
\text { priority }\end{array}$ & $\begin{array}{l}\text { Low } \\
\text { Priority }\end{array}$ & $\begin{array}{l}\text { Medium } \\
\text { Priority }\end{array}$ & $\begin{array}{l}\text { High } \\
\text { Priority }\end{array}$ & Essential \\
\hline $\begin{array}{l}\text { Knowledge of Content in Movement and } \\
\text { Pedagogy }\end{array}$ & $9.09 \%$ & $9.09 \%$ & $18.18 \%$ & $36.36 \%$ & $27.27 \%$ \\
& & & & & \\
$\begin{array}{l}\text { Knowledge of how to represent content } \\
\text { knowledge to make it comprehensible to } \\
\text { learners (i.e., pedagogical content } \\
\text { knowledge). }\end{array}$ & $9.09 \%$ & $9.09 \%$ & $18.18 \%$ & $18.18 \%$ & $45.45 \%$ \\
$\begin{array}{l}\text { Knowledge of processes and methods of } \\
\text { systematic intentional inquiry about }\end{array}$ & $18.18 \%$ & $0.00 \%$ & $0.00 \%$ & $36.36 \%$ & $45.45 \%$ \\
$\begin{array}{l}\text { learning and teaching in physical } \\
\text { education. }\end{array}$ & & & & & \\
\hline
\end{tabular}

Table 6

Prioritization of Standard 2; Professional Practice in PETE Master's Programs (N=11)

\begin{tabular}{llllll} 
& $\begin{array}{l}\text { Not a } \\
\text { priority }\end{array}$ & $\begin{array}{l}\text { Low } \\
\text { Priority }\end{array}$ & $\begin{array}{l}\text { Medium } \\
\text { Priority }\end{array}$ & $\begin{array}{l}\text { High } \\
\text { Priority }\end{array}$ & Essential \\
\hline $\begin{array}{l}\text { Teaching reflects integration of } \\
\text { planning, instruction and assessment as } \\
\text { a unified process to achieve long- and } \\
\text { short-term outcomes/goals. }\end{array}$ & $9.09 \%$ & $9.09 \%$ & $9.09 \%$ & $27.27 \%$ & $45.45 \%$ \\
$\begin{array}{l}\text { Teaching reflects differentiation of } \\
\text { instruction based on personal and } \\
\text { cultural characteristics of learners. }\end{array}$ & $9.09 \%$ & $9.09 \%$ & $9.09 \%$ & $36.36 \%$ & $36.36 \%$ \\
$\begin{array}{l}\text { Teaching reflects systematic inquiry } \\
\text { about the practice and the learners } \\
\text { served. }\end{array}$ & $10.00 \%$ & $10.00 \%$ & $10.00 \%$ & $30.00 \%$ & $40.00 \%$ \\
\hline
\end{tabular}


Table 7

Prioritization of Standard 3; Professional Leadership in PETE Master's Programs $(N=11)$

\begin{tabular}{|c|c|c|c|c|c|}
\hline & $\begin{array}{l}\text { Not a } \\
\text { Priority }\end{array}$ & $\begin{array}{l}\text { Low } \\
\text { Priority }\end{array}$ & $\begin{array}{l}\text { Medium } \\
\text { Priority }\end{array}$ & $\begin{array}{l}\text { High } \\
\text { Priority }\end{array}$ & Essential \\
\hline $\begin{array}{l}\text { Conducts inquiry into professional } \\
\text { knowledge and practice and communicates } \\
\text { results of inquiry to the profession and } \\
\text { community. }\end{array}$ & $18.18 \%$ & $9.09 \%$ & $18.18 \%$ & $27.27 \%$ & $27.27 \%$ \\
\hline $\begin{array}{l}\text { Continues personal development through } \\
\text { contributions to the growth and professional } \\
\text { learning of others. }\end{array}$ & $18.18 \%$ & $9.09 \%$ & $27.27 \%$ & $18.18 \%$ & $27.27 \%$ \\
\hline
\end{tabular}

Table 8

Summary of Theme 1 from Semi-Structured Interviews: Leadership Development Participant Representative Quote

P2 "...emphasis then is on bettering oneself as a learner in order to impact your professional practice and what it is that you do on a day to day basis with your learners."

P1 " Leadership is something that we talk about in regard to you are"

P3 "...take it to the next level and share that project with their school administrator, or their school board - and even yet best - they could decide to take the initiative and share the outcomes of that project, or take it to a greater extent onto their community or even state conference..."

P4 "...how would the build capacity within the spheres of influence, within their communities and beyond?" "... legally to justify what it is that their program does ... how it meets national standards... build that leadership plan for themselves of how they are going to develop across their career"

P2 "...much more of a leadership focus, before we were just looking at giving teachers the next set of skills.... put that aside and decided to go to a different direction." 
Table 9

Summary of Theme 2 from Semi-Structured Interviews: Curriculum Mapping Participant Representative Quote

P1 "...They take a few undergraduate courses and then they take a series of graduate courses. ... 18 hours in physical education... no requirement for any undergraduate physical education courses..."

P2 "...encourage the students to select courses - graduate level courses in our department..."

"Reflection is a component of our physical education program"

P4 "...designed to allow practicing teachers, or professionals in the field to work through professional course work that's really designed to allow them to apply content in their practice - in their school or community based physical activity setting." "...unique advanced laboratory follow up course setting..." "The summer work that they do - 3 credit hours of the bonded work - is followed up with a 1- credit hour advanced lab in either the Fall or Spring semester."

P3 "...information shared and learned in one course can transfer over into another."

P3 "...chances of it (focus on learning rather than teaching) occurring in the middle of the program with the electives may not be as stable as it would be at the beginning or toward the end with the capstone course... integrates all the learning that takes place throughout the entire program."

P3 "...developed... different standards... have an interest in becoming an athletic director, or .... some sort of school district administrator, or ... opportunity to learn about those particular issues." 
Table 10

Summary of Theme 3 from Semi-Structured Interviews: Inquiry-Based Learning Participant Representative Quote

P1 "... our best to bring them up to speed and also introduce them to advanced methods of teaching physical education which we go into in broad depth." "... level of expectations for their performance is much higher than it is for the undergraduate students."

P4 "...take back to their schools, or community setting, and do action research type of project where they identify a problem come up with a plan for implementation - and then evaluate the effectiveness of that plan."

P4 "...program with exposure to principles of effective teaching, and a systematic observation of their own teaching and how that parallels with their taking of a course in curriculum and instructions... how that would facilitate their decision making in regard to what instructional practices..."

P3 "...data driven approach in today's educational context...course that is going to be an assessment and evaluation... to teach people how to do assessments."

P4 "... submit video artifacts ...things that a teacher has to be aware of.... Formal and informal assessments, discipline, management, leadership."

P1 "...having to think about what they had learned in previous courses in order to be strong advocates for physical activities within P.E...." 
Table 11

Summary of Theme 4 from Semi-Structured Interviews: Enrollment Management Participant Representative Quote

P4 "...intentional about providing promotional information to prospective students through a very targeted and automated system." "... worked with the Office of Academic Innovation, and WV online to build in a communication plan for those who inquire about the program."

P4 "...offering maybe some courses for non-degree seeking students. So, some free webinars that might allow them if they were to register and take some of the segments and chunks of our content that would allow them to work towards a degree in a little bit more self-paced manner."

P3 "...very good retention in this program...we take care of our students ... try to get to know them as best we can... we want them to be successful."

P2 "...constantly looking for ways to appeal to students outside of the market that we have traditionally reached..."

P2 "We do use that (leadership) in some of recruitment and marketing materials that program graduates go for"

P4 "... system for information sharing and recruitment that we are going to continue to build to help support interest in students to transition them from just interested into admitted and enrolled students." 


\section{Appendix A}

\section{Extended Review of Literature}

The purpose of this study is to extend previous research regarding PETE graduate programs in the United States and how these programs address SHAPE America's advanced standards within their curriculum. SHAPE America was known as AAHPERD (American Association for Health, Physical Education, Recreation, and Dance) before 2014. The current study aims to address how the PETE master's programs in the US address and adhere to these advanced standards and includes structural analysis of institutional profile and curriculum framework such as instructor profile, student profile, program profile, and admission criteria.

The researcher outlines gaps in current PETE master's program literature, physical education advanced standards and guiding framework (NASPE, 2009), and the relationship to the PETE master's degree, and the need for further research. Furthermore, this review of literature summarizes standards-based education and its relationship to physical education in the United States and provides an in-depth review of the components of SHAPE America's (2009) advanced standards for physical education, and existing undergraduate, doctoral, and master's level PETE literature.

\section{Standards-Based Education}


Brown’s (1983) seminal report, “A Nation at Risk: The Imperative for Education Reform" was one principle factor that initiated the reform of standards-based education in the United States. "A Nation at Risk" generated a sense of urgency to hold education in the United States to standards to fully develop the proficiencies of teachers and K-12 students. In education, standards-based denotes the mode of instructional delivery, assessments, grading, and reporting. Confirming mastery of knowledge and skills is essential in K-12 education, and for teacher candidates (TCs) enrolled in teacher training programs (teacher education) (Standards-Based Definition, 2014).

\section{Standards-Based Physical Education}

Again in 1983, the College and University Physical Education Council (CUPEC) assembled a committee to create guidelines for initial certification for physical education teachers (Zieff, Lumpkin, Guedes, \& Eguaoje, 2009). The guidelines consisted of 23 items which were eventually approved by NASPE (National Association for Sport and Physical Education, now known as SHAPE America, Society for Health and Physical Education) in 1985 at the AAHPERD (American Association for Health, Physical Education, Recreation and Dance) National Convention, and in 1986 by NCATE (currently known as CAEP, Council for the Accreditation of Educator Preparation) (Butler, 2006). Since their establishment in 1987, the standards have been revised several times (NASPE, 2009), mirroring NCATE's changes in accreditation requirements (NASPE/NCATE, 2001). State and local K-12 school districts across the United States use the national standards to develop and revise existing frameworks and curriculum. Ideally, all PETE programs in the United States would follow the SHAPE America initial and advanced standards for physical education teachers. 
SHAPE America is the largest organization of professionals involved in school-based health, physical education, and physical activity. SHAPE America's primary purpose is to oversee the development of standards and guidelines for PETE programs to use as the guiding framework for undergraduate and graduate curriculum. SHAPE America's national standards for teaching physical education define what a TC should know and be able to do at the end point of a quality PETE program. There are two levels of teaching standards associated with PETE. In the first level, SHAPE America outlines initial guidelines for beginning teacher preparation used for initial licensure in physical education following graduation, on the undergraduate and graduate level (NASPE, 2008). Though essential to initial PE teacher licensure, Ayers and Housner (2008) and Taliaferro, Ayers, and Housner (2017) completed an extensive review of initial standards and their components. The review of initial standards is beyond the scope of this study. Research suggests that due to accreditation requirements, much focus has been on the structure and content of undergraduate PETE programs in the United States (Mawer 2014).

\section{Advanced Physical Education Standards}

SHAPE America's advanced standards are intended for advanced teacher candidates who obtain additional academic credits following initial licensure. These credits may serve as continuing education professional development requirements or come in the form of a master's degree. Continuing education and professional development is not an unusual requirement for practicing teachers. One way to obtain professional development and continuing education credits is in the form of a master's degree (Petrie \& McGee, 2012). NASPE (2009) defined this as post-baccalaureate levels for continuing education for teachers who have previously completed initial licensure in physical education. 
Advanced programs typically award 'graduate credits and include master's, specialist, and doctoral degree programs, as well as non-degree licensure programs at the postbaccalaureate level" (NASPE, 2009, p. 55). Little research related to ongoing education and its relationship to expertise in the teaching of physical education exists (Hooper \& Butler, 2013). The advanced standards operate under the assumption that master's degree candidates enter programs with the fundamental "knowledge, skills and dispositions" that a licensed teacher should possess (NASPE, 2009, p. 1). It is the responsibility of the issuing institution to confirm that candidates enter the program possessing the skills delineated in SHAPE America's initial standards (SHAPE America, 2015).

The latest revision to SHAPE America's advanced standards happened in 2009 when NASPE assigned a task force to review and revise its national standards for advanced PETE. During the revision process, the job of the task force was to review current standards, analyze current literature regarding best practices in teaching, and recommend revisions to the existing standards to match these processes (NASPE, 2009).

This revision reduced the number of advanced standards from nine to three. This reduction did not diminish the expectations of advanced TCs (Dr. B.A. McCullick, Personal Communication, August 13, 2015). The original nine standards were rewritten to intertwine all nine standards into three all-inclusive standards. The responsibility of the task force was to develop standards that represented an advanced educator, ensuring the focus was on student learning rather than teaching. Also, providing an integrated knowledge base as opposed to the stand-alone format of the 2001 advanced standards was essential to the revision goals. The revisions stressed the importance of inquiry as a rooted disposition and ensured a higher standard to which advanced PE teachers were held (Dr. B.A. McCullick, Personal Communication, 
August 13, 2015). The task force developed an initial draft of the new advanced Standards for review by "PETE faculty members, K-12 practitioners, college and K-12 administrators, and representatives of other professional organizations" related to physical education (NASPE, 2009, p. VII).

After successive rounds of professional reviews, the task force revised and posted these edits to NASPE's website for member review. The 2007 and 2008 AAHPERD (American Alliance for Health, Physical Education, Recreation, and Dance) conventions provided stakeholders the opportunity to ask questions and offer feedback, and suggestions. The final revisions to the advanced standards were presented to the NASPE Executive Board of Directors for final approval in March 2008 (NASPE, 2009). The revised advanced standards represent a complete model of what a physical education teacher is expected to know and do upon obtaining post-initial licensure (e.g., master's degree).

These 2009 advanced standards are based on the belief "that all students can be physically educated" in an unbiased learning environment (NASPE, 2009, p. VII). Advanced PETE standards also serve as the foundation for a performance-based assessment system which requires TCs to demonstrate foundations classified by SHAPE America as influential in shaping highly qualified teachers (NASPE, 2009). Performance-based evaluation occurs through NASPE (currently known as SHAPE America) developed rubrics. The rubrics identified the four fundamental beliefs that serve as the guiding principles for constructing and classifying the advanced standards, and for developing the rubrics that define unacceptable, acceptable and target performance levels (NASPE, 2009).

SHAPE America's advanced standards are independent of SHAPE America's initial standards and were developed to represent the next step in continuing teacher development. 
Advanced TCs are expected to "form connections among deeper understandings of the knowledge bases, represent and communicate content through meaningful, integrated instruction and, develop a professional identity emanating from rich and varied leadership experiences" (NASPE, 2009, p. 4). Advanced standards set themselves apart from the initial standards in three ways; Improvement of teaching and learning through systematic inquiry, planning and assessing occurring concurrently, tailoring to the needs of all learners, and professional development focusing on the betterment of the profession.

The advanced standards focus on 1) professional knowledge, 2) professional practice, and, 3) professional leadership. SHAPE America's explanation for each standard focuses on framework and justification for selecting the skills and knowledge and performance qualities of a well-informed candidate (NASPE, 2009).

Professional knowledge. Advanced TCs in physical education are expected to enter a master's program understanding the content knowledge, application, and assessment modes that form the preliminary base for instructing physical education. Components that make up physical education teachers' content knowledge necessary for effective teaching (Rink, 2007) is a continual debate. Physical education teachers and future teachers have a should aim to utilize professional knowledge to promote positive health behaviors and outcomes in schools (Goc Karp, Brown, Scruggs, \& Berei, 2017).

Teachers' pedagogical knowledge (PCK) is likely to impact their teaching quality and as a result, student learning (Lenske, Thillmann, Wirth, Dicke, \& Leutner, 2015). Bullock (2011) stated that professional knowledge incorporates "knowledge, beliefs, and values that teachers possess and create in the course of their careers" (p. 23) as K-12 teachers. Candidates who have met the criteria outlined in the initial standards for teaching physical education have foundational 
knowledge in movement and pedagogy coming from kinesiology, education, and educational psychology (NASPE, 2009). According to Rink, French, Lee, Solomon, and Lynn (1994), advanced knowledge requires physical education teachers to apply existing knowledge, teaching, and inquiry into their practice (SHAPE America, 2015).

Barge (2013) argues that critical elements of teacher professional knowledge are subject matter knowledge, pedagogical knowledge, curricular knowledge, and knowledge of the learner. Subject matter knowledge means sustaining current knowledge of the subject matter, and continuing knowledge through professional development and furthering education. Pedagogical knowledge means using appropriate instructional strategies to increase student achievement in the given discipline. Curricular knowledge means adopting applicable standards and having an understanding of expectations for student achievement. Lastly, learner knowledge refers to the K-12 students as learners, acquiring an understanding of the students and their developmental level, and utilizing a variety of teaching strategies (Barge, 2013). These three types of knowledge are fundamental in producing well-rounded teachers who possess the skills, knowledge, and dispositions of a competent practitioner.

Research on teaching general and physical education shows that strong base content knowledge is fundamental to effective teaching (Schempp, Manross, Tan \& Fincher, 1998). Ward (2013) contends that teachers in physical education in the United States are now more than ever held accountable for student learning based on national standards (Dyson, 2014). SHAPE America (2015), states that content knowledge in PETE initially stems from knowledge of movement and pedagogy. Movement knowledge is mastering movement forms (critical elements) and knowledge from areas related to kinesiology such as exercise physiology, sport psychology, and biomechanics. PCK comes from education and psychology as opposed to 
general kinesiology. Examples of related courses include educational foundations, methods courses, instructional technology, child development, and general psychology.

Advanced teachers should keep movement form knowledge current and continually look to expand their knowledge (Banville, White, \& Fox, 2014). Findings from Banville et al. (2014) showed that teachers typically do see themselves as continual learners and apply content and PCK in their schools. Banville et al., (2014) added to the professional development literature in PE by discussing how an "advanced master's degree programs align with teachers' professional settings. These professional settings should reinforce collaboration, incorporate learning communities, and focus on lifelong learning by emphasizing reflection and leadership (p. 577)." Research on professional knowledge in teaching is continually evolving. The consensus is that overall, advanced physical education teachers succeed in relaying content knowledge in their teaching (Bates, Swennen \& Jones, 2014; Jin, Shin, Johnson, Kim, \& Anderson, 2015; SHAPE America, 2015).

PCK, or how teachers organize and present subject matter in practice (Shulman, 1987) is the combination of content and pedagogical knowledge (Shulman, 2004a). PCK empowers teachers in predicting and recognizing barriers to student learning and helps teachers take action to find a solution (Schempp et al., 1998). The advanced teacher should tailor content and PCK to suit the needs of an ever-changing and distinct student population (Shulman, 2004b). Advanced teachers are expected to look beyond teaching and habitually reflect and collaborate to perfect their practice (Shulman, 2004b). The recommendation is that advanced teachers compile research-based findings that support their commitment to improving teaching practice and knowledge and use what they have learned as a building block for the application of skills, review, and assessment of teaching and learning (SHAPE America, 2015). 
Professional practice. Professional practice, the second advanced standard, focuses on the teachers' ability to validate, incorporate, and utilize the pedagogical skills, professional knowledge, and dispositions obtained during all stages of teacher preparation (SHAPE America, 2015). Teaching should enhance K-12 students' development in the cognitive, affective, and psychomotor domains of learning. Professional expectations of teachers are continually evolving (Dixon \& Ward, 2015). Schon (1987) and Shulman (2004b) discussed the shift to teach as a practical activity, resulting in a shift from teacher training to teacher education (Dixon \& Ward, 2015). These broad shifts altered teaching practices from practical activity to a complex and more specialized activity (Alcorn, 1999; Dixon \& Ward, 2015). For recent graduates, connecting professional preparation and the workforce can be a sizeable task (Ensign, Woods, \& Hodges, 2017). In some instances, once enthusiastic expectations conflict with the reality of the daily requirements for teachers (Ensign et al., 2017).

Interestingly, over $40 \%$ of novice teachers exit the profession within the first five years (Perda, 2013). This significant fact is linked to the importance of retaining practicing teachers past the first five-year mark and beyond. The induction years are a crucial time for developing teaching practices. These foundational introduce varying new experiences and aid in developing the functions of effective teaching. Positive professional development experiences are crucial at this juncture (Ensign et al., 2017).

Effective practice is established on theoretical foundations, and as a result, research has played a vital role in constructing and revising the professional practice theory (Dixon \& Ward, 2015). Teachers (K-12) are expected to engage in reflection on an individual and collective basis (Dixon \& Ward, 2015). As a result, professional expectations for teachers seeking initial licensure versus practicing teachers "have changed thus requiring practicing teachers to forge 
new professional identities" (Dixon \& Ward, 2015, p. 52).

Teacher development may happen through hands-on learning experiences (NASPE, 2007) in a movement environment that prepares K-12 students to become active members of society. The focus of instruction serves K-12 students by allowing them to obtain "movement skills and knowledge," and develops skills to have power over the management of their decisions (Mosston \& Ashworth, 2002, SHAPE America, 2015). Professional practice means aligning planning, instruction, and assessment. These three components are intended to be viewed as a whole meaning one cannot take place to produce effective learning without the others (SHAPE America, 2015). Professional practice for advanced teachers means including content knowledge and PCK when creating, instructing, and assessing developmentally appropriate units and lessons (SHAPE America, 2015).

Advanced teachers should align and apply lesson objectives (short-term) and unit objectives (long-term) to national standards. Clear objectives may help students recognize goals suited to their developmental level. Advanced teachers should differentiate instruction to suit individual learner experiences, needs, and preferences, and connect learning experiences to prior knowledge and experiences (NASPE, 2007). To connect prior and current knowledge, advanced teachers should use a wide range of teaching methods and support learners in self-monitoring progress. The self-monitoring taught by advanced teachers may aid in critical thinking and problem solving as part of learner development. Advanced teachers should show concern for instructional effectiveness and ensure continual analysis of instructional strategies for effectiveness. They relate teaching practice comprehension to formulate questions, gather and analyze information, and to use results to enhance instruction (Shulman, 2004c). Advanced teachers extend the process by including students in the inquiry process. 
Professional leadership. Teacher leaders may share expertise in a variety of ways (Nappi, 2014). Teacher leadership is a "set of skills demonstrated by teachers who continue to teach students but also have an influence that extends beyond their classrooms to others within their school and elsewhere" (Danielson, 2006, p. 12). Nappi (2014) states the role of teacher leader remains largely undefined due to the wide variety of activities and roles that teachers take part in involving leadership, and defined 10 roles of teacher leaders as: "resource provider, instructional specialist, curriculum specialist, classroom supporter, learning facilitator, mentor, school leader, data coach, catalyst for change, and learner (p. 2)." Wenner and Campbell (2017) studied the teacher leadership literature since the seminal works of York-Barr and Duke (2004) in teacher leadership. Taking note of the date of teacher leadership seminal works (2004), it is evident that teacher leadership is a newer point of research than some other trends in teaching research.

Due to the overall rise in the national obesity epidemic, physical education teachers across the nation have been tasked as leaders of physical activity promotion through the use of a Comprehensive School Physical Activity Program (CSPAP) (Deuahnauer et al., 2017). Several recent studies (Bulger et al., 2017; Deuahnauer et al., 2017; Goc Karp et al., 2017; Sundaresan, Dashoush, \& Shangraw, 2017; Zhang, Gu, Zhang, Keller, \& Chan, 2018) have named teacher leadership and its essential relationship to the CSPAP. In December 2015, the authorization of Every Student Succeeds Act (ESSA) identified physical education as a component of "wellrounded education," a term that has replaced "core academic subjects" (Wright, 2015). There is a need now more than ever for teacher leaders who create and implement well-rounded and meaningful pre and post formative, summative, and standards-based assessments covering the cognitive, psychomotor, and affective domains of learning (Sundaresan et al., 2017). 
According to the International Journal of Leadership in Education, Fairman and MacKenzie's 2015 study named the importance of teachers' responsibility as a leader in both direct and indirect leadership roles. The importance of teacher leadership in schools is second only to classroom instruction as teacher leaders can lead by forging connections and collaborations with colleagues. Expectations for advanced teachers are to continue professional development and use that development to contribute to the profession as continuous and collaborative learners (Hord, 1997). Continuous and collaborative learners pursue, share, and act on learning (Hord, 1997) for the benefit of students (SHAPE America, 2015). In a general sense, leadership is about continuous learning through professional learning communities, ongoing investigation of practice, and a commitment to decision making within the school (Hargreaves \& Fink, 2006). According to Nudrat and Akhtar (2014), teacher education institutions and programs play a significant role in the emergence of teachers as leaders.

Teachers who see themselves as leaders can create teaching and learning practice, practice classroom management, and work with administrators toward improving the school (Nudrat \& Akhtar, 2014). Literature in education highlights a key objective of teacher education is to create teachers who can grow and develop themselves into leaders. Teacher leaders play a definite role in the advancement of modern education (Cherubini, 2008). Nudrat and Akhtar (2014) also point out that teacher leaders have the potential to be contributory in introducing and implementing a significant pattern shift from a traditional school to an effective learning community.

In 2008, Easton referred to the terms professional learning, professional training, and professional development as separate entities. Continuous learning requires inquiry, reflection, and collaboration for teachers to learn from one another and redirect leadership roles (Easton, 
2008). Collaboration refers to communicating and sharing knowledge. Teacher communication is a leading source of professional learning and instructional improvement (Sparks, 2003). Advanced teachers build upon reflection through inquiry from the bottom up. Advanced teachers may ask themselves what students need to know (Fenstermacher, 1994), and use that information to refine their practice to help students achieve learning objectives (Easton, 2008). Practice refinement encourages continuous questioning of "student work, assessments, organization structures, and content in a supportive, reciprocal environment that honors the contributions of school staff members, as well as those of educators" (SHAPE America, 2015, p. 11).

Leadership that makes student learning a central focus may be made possible through collaboration with fellow teachers, parents, and administrators (SHAPE America, 2015). Including others in student learning initiatives helps reinforce positive connections (NASPE, 2009). Advanced teachers should support and maintain leadership by prioritizing student learning as the chief component in leadership initiatives. Teacher leaders make student learning evident to fellow teachers and administrators, and represent leadership through ongoing knowledge analysis (NASPE, 2009). Lastly, advanced teachers encourage adult learning through their leadership development and the development opportunities offered to others to make leadership a shared process (Hargreaves \& Fink, 2006). Advanced teachers who exhibit professional leadership qualities are vital to advancing physical education and professional learning in K-12 schools (NASPE, 2009).

The teaching profession as a standalone entity typically offers few opportunities for career advancement where teachers take on leadership roles (Day \& Gu, 2007). Continued advancement is crucial in recruitment and retention of quality teachers (Day \& Gu, 2007; Muller 
et al., 2009). Often, teachers look for pathways to improve their career, stimulate new learning, and uphold teaching motivation. Additionally, teachers may seek professional networking through professional development (PD) as a source of support from others (Margolis, 2008). PD is often regarded as a fundamental cornerstone of teacher advancement (Margolis, 2008). PD provides opportunities for teachers to enhance knowledge and develop new instructional practices. When done well, PD holds the potential to enhance career satisfaction, improve retention, and improve the quality of student learning (Bohmer, Glock, \& Krolak-Schwerdt, 2014). According to Bohmer, et al., (2014), since the turn of the century, the examination of school quality has paid more attention to teachers' PD. Contemporary views of PD describe PD as a long-term process extending from teacher education programs to in-service training at the workplace (Bohmer et al., 2014; Moon, 2013). Effective physical education PD also reported promising outcomes such as enhanced content knowledge (Makopoulou \& Armour, 2014), changes in teacher identity (Armour \& Yelling, 2007), increased teacher learning capacity (Deglau \& O’Sullivan, 2006), and teacher empowerment (Parker, Patton, Madden \& Sinclair, 2010). Acknowledging this potential, Armour (2014) and Bohmer et al. (2014), advocate that teachers have both the right and the responsibility to engage in effective continuing PD throughout their careers and argues that PD must be an integral part of teachers' professional lives.

Darling-Hammond's (2008) research supports this continuation of learning by studying, education, and collaborating with other professionals. Acquiring sophisticated levels of knowledge is a critical component to teacher effectiveness that requires more than reading and talking (Ball \& Cohen, 1999). This kind of learning cannot occur in college classrooms that separate themselves from teaching practice but is most effective when applying and solving real 
works in progress (Darling-Hammond, 2008). These application-based programs have been making headway over the last 20 years, beginning predominantly with bachelor's degree programs, and slowly lending itself to advanced degrees, five-year programs, where the task focuses more so on refining teaching practice and less on pedagogical coursework reserved typically for undergraduates (Darling-Hammond, 2008).

Teacher leadership has received increased attention (Margolis \& Deuel, 2009;

Lieberman, \& Miller, 2011). Broadly conceived, teacher leadership came from authority, often as a result of a selection process and manifested formally through roles such as leaders of curriculum areas or heads of departments in secondary schools (Bohmer et al., 2014). Alternatively, teacher leadership may be informal through the influence that does not involve designated authority over peers (i.e., coaching colleagues). Various advanced certification or assessment schemes have enabled teachers to demonstrate specialist expertise to recognize teacher leaders. Other examples of professional leadership include attending or presenting at professional conferences and workshops, serving as a mentor to novice teachers, leadership opportunities through professional practice, and other initiatives. According to Poekert, Alexandrou and Darbiann (2016), teacher leadership is increasingly being presented as a useful answer to guide teacher learning, school improvement, and policy reform. Poekert et al., (2016) also noted that teacher leadership development is positioned in the framework of the classroom, the school, and the community. Each of these places plays an integral part in developing a wellrounded teacher leader. Due to broadening expectations placed on physical education teachers, it has become essential for programs preparing teachers to provide training for teachers can perform essential leadership functions inside and outside of teaching (Dauenhauer et al., 2017; Erwin, Beets, Centeio \& Morrow, 2014). 
Bagley and Margolis (2018) referred to this as HTL (hybrid teacher leadership). HTL focuses on teaching K-12 students and becoming leaders outside of the classroom in some capacity, most notably through leading other teachers in the form of professional development, administration, and so forth. Bagley and Margolis (2018) reinforced the crucial roles of hybrid teacher leaders, listing career exploration outside of the classroom as a primary benefit of HTL. The authors defined career exploration as exploring roles beyond teaching on a full-time basis. Professional learning is required on various levels, with some taking place as continuing education. Regardless professional learning must be ongoing and advance teaching practices (SHAPE America, 2009). Thus, the focus is streamlined through professional practice and integrating knowledge and skills into teaching practices.

\section{Framework for Advanced Standards}

SHAPE America outlined four principles meant to serve as a guiding framework for the advanced standards. These principles set the advanced standards apart from SHAPE America's initial standards by serving as a direct underpinning to show the progression from one standard into the next. The standard of professional knowledge acts as a foundation, transitioning into the importance of content knowledge and its application to professional practice (SHAPE America, 2015). Following professional practice, professional leadership outlines expectancies, the use of advanced skills, knowledge, and dispositions to develop the profession (NASPE, 2009).

The four principles focus on learning rather than teaching, integrated knowledge base, the importance of inquiry, and the role of leadership. The four guiding principles are used in the development of rubrics for advanced candidate evaluation, describing performance criteria for the advanced candidate at levels of unacceptable, acceptable, and target (SHAPE America, 2015). These four guiding principles operate under the assumption that novice teachers are 
aware of the four domains that play a role in effective physical education teaching. These are the affective perspective (Dyson, 2014), the cognitive perspective (Ennis, 2014), the motor skills perspective (Rink, 2013), and physical activity (McKenzie \& Lounsbery, 2013). Each domain combines to form teacher content knowledge necessary for a comprehensive program (Rink, 2014).

Focus on learning rather than teaching. Focus on learning rather than teaching states that emphasis should be on K-12 student learning outcomes rather than an evaluation of teaching (NASPE, 2008). When the focus is placed on student learning, assessment practices are an essential part of teacher learning. Assessment means gathering information about student learning and performance to improve teaching and educational practices (Assess Teaching and Learning-Teaching Excellence and Educational Innovation, n.d.). The standards and evaluation rubrics characterize the belief that teaching focused on learning outcomes and experiences is imperative to student learning (Huba \& Freed, 2000; Hargreaves \& Fink, 2006; NASPE, 2008). The expected outcome is for students to invest in creating their own active and healthy lifestyle, thus taking responsibility for their health and wellness (SHAPE America, 2015). Data analysis can provide a picture of students' current knowledge, what they need to know, and what can be done to achieve those learning goals (Maass \& Engeln, 2018). Use of student learning data allows instructors to make informed decisions that positively affect outcomes.

Analysis of student learning date can provide a picture of students' current knowledge, what they need to know, and what can be done to achieve learning goals. Student data allows instructors to make informed decisions that positively affect outcomes. Maass \& Engeln (2018) stated that it is essential to provide high-quality inquiry-based learning in professional 
development on a large scale. Teachers are expected to differentiate instructional practices to suit various learning abilities to help students achieve responsibility for their health and wellbeing. Therefore, these advanced standards do not recommend specific courses and proficiencies for advanced teacher candidates or their progression in learning (SHAPE America, 2015). Instead, they focus on what candidates know and how they can convey that information to students.

Integrate knowledge base. The approach to the integrated knowledge base states that a forward-thinking teacher must possess a cohesive body of knowledge and skills. The seminal works of Berliner (1994) and Clark and Peterson (1986) discussed the importance of an integrated knowledge base relating to teaching expertise. The teaching literature leaves questions about the content taught, the questions asked of students, and explanations offered as a result of these questions (Shulman, 2013). Shulman (2013, p. 5) outlined "the importance of knowing where teacher explanations come from, how teachers decide what to teach, how to represent it, how to question students about it and how to deal with problems of misunderstanding?"

Questions such as these have typically been focused from the learners' perspective, neglecting teacher perspective regarding these issues. We assume that most teachers begin with some expertise in the content they teach. Typically, secondary education TCs complete a major in their area of expertise. Content knowledge from the teachers' perspective comes from three categories: 1) content knowledge of subject matter, 2) pedagogical content knowledge (PCK), and 3) content knowledge related to curriculum.

Importance of inquiry. The third framework emphasizes the teacher as a reflective practitioner. The development of reflective habits in teachers is an integral part of teacher education (Horng-Yi, 2014). Inquiry involves questions. To the average learner, inquiry-based 
teaching may be construed as merely asking questions. The focus of inquiry-based learning is on the type of questions asked to convey lesson objectives through self-discovery learning.

Nonetheless, it is both a pedagogical approach and strategy for learning. Through questioning, the central value of inquiry-based pedagogy stresses learning through discovery as well as learner development of cognitive and metacognitive strategies (Horng-Yi, 2014). Inquiry is considered appropriate for initial teacher candidates. Teachers who have completed a graduate program are held to a higher standard of inquiry (NASPE, 2009). Horng-Yi (2014) stated that knowledge is entrenched in insightful thinking inspired by questions. Questioning techniques should strive to drive the class focus toward the lesson content and learning objectives. Inquirybased teaching differs from typical direct instruction by encouraging higher order thinking through cognitive and discovery learning. Teachers are not encouraged to teach directly, and expectations are that students discover knowledge on their own, which directly translates to problem-solving and inquiry in real life situations. The teacher is viewed as an enabler to help students discover and build their knowledge. According to Shulman (2004b), reflection is a critical component of teaching if one hopes to become a master teacher. Greater understanding of how student engagement with genuine inquiry-based approaches is needed to aid in designing more meaningful experiences for students (K-12) in physical education (Kretchmar, 2000; Enright \& O'Sullivan, 2012), and for developing a curriculum to enhance physical education and experiences beyond the classroom (O’Connor, Jeanes, \& Alfrey, 2016).

Authentic inquiry-based learning can contribute to meaningful and engaging learning experiences. Extra support for teachers is needed, specifically, foundations of approaches to critical inquiry that augment knowledge relevant to topics identified by the learner, a focus on authentic assessment, and aligning these with inquiry-based learning classroom (O'Connor et al., 
2016). Inquiry-based learning results from interviewees yielded three subthemes as areas of importance in effective teaching, data-driven teaching effectiveness, and course assessments to reflect inquiry-based learning. The use of models-based instruction in physical education can be a useful tool for rational instructional practices; however, models-based-practices should work in conjunction with a thoughtful and thorough physical education program (Landi, Fitzpatrick, \& McGlashan, 2016).

More recently, reflection has presented itself as a central measure of initial teacher certification. US states requiring high stakes performance-based assessments to obtain initial certification utilize reflection of planning, instruction, and assessment to determine the TCs ability to modify plans to suit the needs of all students (Metzler, 2014). Initially designed for social issues and employed in 1946 by K Lewin, action-based research is a valuable method for executing change through planning, acting, observing, and reflecting (Keegan, 2016). Keegan's (2016) research found that action research was effective in helping PE teachers enhance student (K-12) learning.

Role of leadership. Inquiry into practice and sharing of results leads to the role of the teacher as a professional leader (NASPE, 2009). Recent literature has shown that teacher leadership has gained popularity and connects successful teachers with strong leadership skills (Stein, 2014). Stein (2014) stated that effective teachers as classroom leaders are those who know students, create a constructive environment, are accountable for student learning, know how to motivate students and have a future vision for themselves and their students. Wenner and Campbell (2017) studied the teacher leadership literature since the seminal works of YorkBarr and Duke (2004) in teacher leadership. Taking note of the date of teacher leadership seminal works (2004), it is evident that teacher leadership is a newer point of research than some 
other trends in teaching research. The importance of teacher leadership in schools is second only to classroom instruction as teacher leaders can lead by forging connections and collaborations with colleagues. What exactly constitutes a teacher leader remains widely diversified. Teacher leaders hold many titles, including coach, mentor, department chair, and so on (Wenner \& Campbell, 2017).

Shulman (2004c) stated that being a professional leader means that advanced teachers should explore their teaching and also teach under investigation. Therefore, the second principle of integrated knowledge base must include the "skills, knowledge and dispositions to inquire about teaching (professional knowledge), contribute to the professional learning of others to advance the profession (professional leadership), which ultimately, benefits students (professional practice)" (NASPE, 2009, p. 12).

\section{PETE Curriculum}

Effective education starts with a strong curriculum. Lund and Tannehill (2010) define curriculum as the knowledge and skills offered to students in the school program. This holds for K-12 curriculum and curriculum in teacher education programs. The curriculum includes learning experiences that provide students with the tools and knowledge to reach the specific goal and serve as the blueprint for what students are expected to achieve (Lund \& Tannehill, 2010; Tinning, 2006).

Educating future teachers combines the formal and non-formal activities and experiences that help to prepare a preservice teacher. The goal of teacher education programs is to produce competent novice teachers (McArdle, 2010). The starting point of that goal begins with teacher education programs and teacher preparation practices (McArdle, 2010) in undergraduate PETE. By researching undergraduate PETE curriculum, the hope is that the findings will be used to 
enhance curricula in PETE master's degree programs in the United States.

\section{Undergraduate Curriculum in PETE}

Expectations of future physical education teachers (Siedentop \& Locke, 1997) encompass quality PE, effective PETE programs, and a working relationship between the two. According to Wiegand, Bulger, and Mohr (2004), PETE curriculum is in need or continuous review and evaluation. This continuous review and evaluation is echoed by Ayers and Housner's (2008) descriptive study, and Taliaferro, et. al (2017). The framework for a study of PETE undergraduate curriculum by Wiegand et al. (2004) included "1) foundational subdisciplinary coursework, 2) curriculum and instruction coursework, 3) PCK coursework, and 4) field placement experiences" (p. 47) as areas of study in professional preparation.

Subdisciplinary courses. Subdisciniplary courses refer to courses intended to increase the knowledge base of PETE students and may consist of motor development, biomechanics, exercise physiology, and others related to general kinesiology content. (Bahneman, 1996; Corbin, 1994; Estes, 1994). The goal of subdisciplinary courses is to help PETE candidates form connections between subdisciplinary knowledge and teaching physical education (Wiegand et al., 2004). O'Sullivan (1990) takes this a step further stating that PETE programs also include liberal arts courses, which are the parts of learning that promote general intellectual ability. O’Sullivan (1990) stated that little evidence concludes that practicing physical education teachers integrate this subdisciplinary knowledge into their teaching. Consequently, Wiegand et al. (2004) argue that subdisciplinary coursework included in PETE curriculum concerning its relevance and applicability to PE instruction is a topic for examination. These courses should prove their relevance by laying the foundation that stimulates student commitment to the profession and increases prospective teacher readiness, and ability integrate subdisciplinary 
concepts in the K-12 setting (Wiegand et al., 2004)

Curriculum and instruction. Curriculum and Instruction (C\&I) courses are critical to the PETE program. In C\&I coursework, preservice teachers learn to enhance planning, implementing, and assessing their instruction in physical education. Knowledge of C\&I should be applied to enhance PCK knowledge that follows as TCs progress through their PETE program (Wiegand et al., 2004). According to Wiegand et al. (2004), the importance of applying C\&I knowledge in a variety of field experiences/teaching environments during the undergraduate experience is crucial. Wiegand et al.'s (2004) study also made the connection between the pedagogical relevance of C\&I courses and the professor/instructors' role in aiding students' understanding of its application. Understanding of C\&I application may lead to methodically designed field experiences reinforcing the purpose of C\&I coursework

Professional content knowledge. The purpose of PCK courses is to link theory to practice in PE and encompass the understanding of instructional methods and subject matter necessary to facilitate student learning (Wiegand et al., 2004). PCK courses serve as a solid foundation in the undergraduate PETE curriculum or the "instructional backbone" of a teacher education program. O'Sullivan (1990) noted that PCK courses are major courses in physical education focusing on skills in sport and fitness. PCK courses should be organized into three categories, separated by the development of school-age children to show that physical education curriculum progresses sequentially to show the development of "motor foundations in K-12 programming” (Wiegand et al., 2004, p. 51). These three categories from a developmental perspective are elementary block/semester, middle school block/semester, and high school/secondary school block/semester. PETE candidates should be prepared to continue into a field experience related to that developmental age group (Wiegand et al., 2004). 
Field experiences. Another term for pre-professional or practice teaching settings for TCs is field placements. Field placements are created to afford TCs the opportunity to apply knowledge throughout their experience in a classroom/gymnasium setting. It is important to note that field placements do not always yield effective teaching by the TC (Wiegand et al., 2004). Housner (1996) suggested that guidelines be imposed to aid the TC in transitioning theoretical knowledge into professional practices during field experiences. These experiences are designed for the preservice teacher to interact with children and faculty members in the school setting. Field experiences also include observations of peers and cooperating teachers during teaching internship or student teaching (O'Sullivan, 1990). PETE programs should strive to incorporate as many authentic field experiences throughout their curriculum (Wiegand et. al, 2004). According to Hill and Brodin (2004), physical education teacher education programs must provide instructional opportunities to meet the challenges presented in today's school systems. The systematic nature of coursework addressed by Wiegand et al. (2004), yields a strong case for a "lock-stepped" curriculum. Lock stepped is a curricular model, which the students' progress through all curricular experiences in a prearranged order.

Ayers and Housner (2008) conducted a descriptive analysis of PETE programs in the United States. Ayers and Housner (2008) state NCATE (currently known as CAEP) has been a critical player in the way that universities prepare undergraduate TCs. The quality of TC preparation is critical in producing effective novice teachers. It is the expectation that undergraduate PETE programs from accredited institutions will follow the initial standards for physical education teachers. NCATE's requirements are for the university programs to provide evidence of student learning, professional dispositions, and the achievement of the knowledge and skills necessary to be effective physical education teachers. Several factors have led to 
undergraduate PETE programs following NASPE's standards for initial licensure. One recent implementation is that of the health-related fitness standard in the PETE curriculum. Next, technology in physical education has made advances since the mid-'90s, leading to technology standards within the NASPE requirements. Overall, Ayers and Housner's (2008) findings show that standards-based curriculums are a driving force in quality PETE programs.

Programmatic demographics. Ayers and Housner (2008) found that the location of approximately two thirds (66\%) PETE programs were housed in a college of education. Additional locations include departments of health and human performance, health and human services, and arts and science. Of participating programs, most (80.2\%) award a Bachelor of Science degree. Approximately half (54\%) prepare program graduates as licensed K-12 teachers, and another one third (31\%) prepare P-12 teachers. The majority of programs offered health as an area of expertise, and certifications in a variety of areas could be completed (CPR, WSI, coaching) (Ayers \& Housner, 2008).

\section{Programmatic Requirements}

The majority (98.2\%) of surveyed institutions reported using a semester format with their programs. Very few reported the use of quarters or trimesters. The authors categorized coursework into four categories for degree completion. The categories are sport and physical education (anatomy, sport sociology/psychology, motor learning), pedagogical content (methods, curriculum, skill analyses), sport skills and physical activities (basketball, dance, tennis), and professional issues (introductory courses, multicultural courses) (Ayers \& Housner, 2008).

Student teaching. The majority $(98.3 \%)$ of programs surveyed offered student teaching placements in an elementary setting, most (96.5\%) in the middle school setting, and all programs 
surveyed offered placements in the high school setting with two to four observations at each placement. A large percentage (76.3\%) of respondents reported their PETE faculty members completed student teacher supervision. College of education faculty conducted approximately $15 \%$ of PETE student teacher supervision, while the remaining $5 \%$ reported that college personnel took on student teacher supervision duties.

Curricular models. Ninety-six programs responded to the curricular portion of the survey, with approximately half (50\%) representing the use of a particular curricular model (Ayers and Housner, 2008). Amongst the 48 programs identifying the use of curricular models, the majority stated that they utilized two or more models (73\%). The model utilized most was the sport education model (52\%), skill themes (33\%), and fitness education $(25 \%)$.

Technology. The overwhelming majority of respondents (97\%) reported including technology in their PETE undergraduate curriculum. Experiences most commonly used included development of portfolio (45\%), specific technology coursework required (38\%), and technology entrenched throughout all coursework (24\%) (Ayers \& Housner, 2008). Creating superior physical education teachers stems from students' progression through a quality PETE program of study (Hetland \& Strand, 2010). According to NASPE (2007), PETE programs should be designed with the goal of creating high-quality physical education teachers by the time they enter the job market. SHAPE America's standards outline the components of quality teacher education programs as including the ability to provide preservice PETE teachers with considerable pedagogical and content knowledge, offering opportunities for preservice teachers to become involved in experiences within the school setting, interaction with teachers and students in diverse contexts, interaction with a variety of grade levels to employ practices learned during undergraduate studies, and developing their professionalism, and to maintain professional 
dispositions throughout the program. To summarize, PETE program goals are to produce highly qualified and capable physical education teachers (Anonymous, 2014). These highly qualified teachers are expected to encompass knowledge in the psychomotor, cognitive, affective, healthrelated fitness domains, all while incorporating technology into their physical education programs.

Hetland and Strand (2010) examined the makeup of PETE curriculum in the Central District, describing PETE programs at institutions located within the Central District of the United States (CDAAAHPERD). This study described the general profile/practices of undergraduate PETE programs and provided an overview of similarities and differences among participating universities. Of the 72 institutions invited to participate, Hetland and Strand (2010), had a 58\% return rate. The survey included essential program information, program curricular information, and analysis of many areas of course content (Hetland \& Strand, 2010).

Hetland and Strand collected data in the spring of 2009 from PETE faculty members employed by colleges and universities located within the AAHPERD Central District using Survey Monkey, an online survey tool. The findings were descriptive and were not intended to represent all institutions and universities located in the Central District. The following categories were used to organize data; "program profile, professional activity courses, skill and fitness testing, observation/ field experiences, student teaching, practical teaching experiences, curriculum content, student professional organization involvement, and advisory boards" (Hetland \& Strand, 2010, p. 5).

Program profile. The average PETE program located in the Central District included approximately 50 total students, with approximately 12 of those students graduating per year. PETE undergraduate students were required to complete 122 credits to graduate and maintain a 
minimum of 2.5 GPA. NCATE accredited most of the programs and used NASPE's Standards to frame coursework $(97 \%)$.

Professional activity courses. Participants were first asked to recognize whether the professional activity courses offered were single or multiple-credit courses (Hetland \& Strand, 2010). The majority of respondents $(86.4 \%)$ indicated that professional activity courses were offered as multiple-credit courses. Overall, students were required to complete an average of 9 credits in professional activity courses. Participants were asked to point out which format most closely matched the professional activity courses offered at their institution. Options were categorized by age (elementary, middle school or high school), type (individual, dual, team, and combative), or activity (court, net, long/short implement) (Hetland \& Strand, 2010). The most common format for professional activity courses was a multiple-credit course, categorized by type (45\%), followed by multiple-credit course categorized by age (20\%), single credit course (14\%), and multiple- credit course categorized by activity (7\%) (Hetland \& Strand, 2010).

Skill and fitness testing. About half of programs required PETE students to pass skill tests and a small percentage required skill tests as a requirement for graduation. About one quarter required students to pass fitness tests in courses, with very few requiring PETE students to pass fitness tests as a graduation requirement.

Curricular issues. During the PETE undergraduate experience, students were required to complete some field observation within their profession. Findings indicated that the most significant number of observational hours occurred in year three of the program — the number of observation hours completed at different grade levels varied (elementary, 26 hours; high school, 23 hours and; middle school, around 17 hours) (Hetland \& Strand, 2010). 
Student teaching. The average time for a student teaching experience was 14 weeks.

Student teaching in PE occurred at three age levels (elementary, middle school, and high school) at less than one-quarter of participating universities. Primary and secondary only were required at the majority of participating institutions. Lastly, a small percentage required middle school placements only. Practice teaching sessions were included in the undergraduate PETE curriculum.

Curricular items. Curricular items incorporated into undergraduate PETE programs most frequently were "national or state standards (86\%), curriculum models (79\%), concepts of fitness and wellness (75\%), and the appropriate practices documents (68\%)" (Hetland \& Strand 2010, p. 6). Hetland and Strand's (2010) descriptive analysis indicated areas in need of further research are specific areas of study such as student teaching and investigating how institutions convey their information to students' national standards. Moving into the analysis of graduate coursework and the graduate curriculum in PETE is one way to continue helping professors to connect PETE curriculum to the National for PETE.

Keeping with the successive nature of undergraduate PETE research, Taliaferro, et. al's 2017 Descriptive Analysis of the application of PETE Standards further expanded on the findings from Ayers and Housner (2008). The aim of Taliaferro, et. al's 2017 study was based on recommendations for future research from the 2008 study (Ayers \& Housner) and examined undergraduate PETE programs strategies to assess SHAPE America's six initial standards (Naspe, 2008), and how technology and diversity is addressed within the undergraduate PETE curriculum.

Taliafeerro, Ayers, and Housner collected data from 156 program directors from 44 states and 1 U.S. territory (2017) using a modified version of Ayers and Housner's (2008) study. 
Responding programs varied in size. Findings included "Program Demographics, Strategies Employed to Assess PETE Standards, and Strategies Employed to Address Technology and Diversity (Taliaferro, et. al, 2017, p. 611).

Program demographics. Trends show that non-Caucasian faculty and TCs are underrepresented in PETE programs (Ayers and Housner,2008). Boyce, et. al's (2015) study echoes this, though the percentage of non-Caucasian faculty shows a slight rise in recent years. Most recently, Taliaferro, et. al's (2017) study showed this lack of diversity (91\% Caucasian) continuing in PETE programs. The TCs show a gradual rise in diversity. Twenty-one point three present self-reported as non-Caucasian.

It is important for this trend to continue to show that future teachers (TCs) more accurately represent the student population that they will one day teach. Strategies for recruitment and retention of highly qualified (Bulger, et. al, 2015).

Standard 1: scientific and theoretical knowledge. Fifty-three-point two percent of respondents to this study indicated the use of SHAPE America's initial standards. The assessment methods for standard one lacked diversity and practical application. Teaching theoretical based courses using practical application may prove difficult (Bulger \& Housner, 2007). PETE programs can use these strategies to make explicit connections between the various disciplines and best practice in teaching PE: (1) Connecting theory to practice (2) Variability of assessment methods, (3) Frequent learning in alternative settings (4) growing professional expectations.

Standard 2: skill and fitness-based competence. Bridging the disconnect in PE from a sport-based environment to individual and noncompetitive activities continues to be a 
widespread emphasis in K-12 PE. Taliaferro, et. al (2017) suggests that the K-12 PE teachers play a large role in shifting the sport-based focus of K-12 PE to lifetime and fitness activities. There is a need to provide lifetime-based fitness activities to offer the K-12 students' options that will closely resemble adult exercise and physical fitness activities.

Standard 3: Planning and implementation. TCs must be able to plan and demonstrate fitness and sport skills to K-12 students. This ties directly into instructional effectiveness and planning effectiveness. Standard 3 is critical to generating a well-designed and effective K-12 curriculum and is in need of reform in the United States (Taliaferro, et. al, 2017)

Standard 4: Instructional delivery and management. PETE programs have placed a greater emphasis on evidence0based curricular models. This is a shift in frequency from Ayers and Housner's (2008) study. Instruction contains management plans and plans for communication and adaptation in diverse teaching situations. This aspect is in need of further investigation.

Standard 5: Impact on student learning. The role of the teacher in K-12 student learning includes increased accountability for documenting student learning. This study shows that grading and assessment measures in PE is in need of improvement. Authentic assessment is quickly becoming imperative in teacher accountability and certification. Authentic assessment strategies are critical to student success and skill measurement.

Standard 6: Professionalism. The primary focus of this study was not centered around professionalism, ways to nurture professional principles, professional performance, and professional attitudes related to socialization is a newer area of focus in PETE and is in need of greater attention (Taliaferro, et. al, 2017). 
Strategies employed to address technology and diversity. Findings in this study

showed that technology is predominantly a standalone course, which is a direct contrast to Ayers and Housner's (2008) study, which showed that aspects of technology was integrated into coursework. More schools are utilizing a variety of technology more so each year, and technology is moving beyond PE specific technology to all encompassing (iPad). It is critical for TCs to remain current in their knowledge or technology to apply this to K-12 student learning. Coursework was utilized by Ayers and Housner (2008) as a predominant approach to address diversity and multiculturalism. Taliaferro, et. al's (2017) study shows an increase in multiculturalism via coursework, and 96\% responded indicating that adapted physical education coursework was a requirement. This is a significant improvement.

\section{Doctoral Curriculum in Physical Education}

After reviewing the literature, one of the few studies on doctoral programs in PETE came from Franks (1988). Characteristics of graduate education in kinesiology, physical education, and sport science include a shift from a professor/instructor directed learning experienced in undergraduate studies to the self-directed learning that follows in graduate school (Franks, 1988). The composition of graduate school is the continuance of courses prepared around desired competencies and learning outcomes. Clinical experience (student teaching, pre-professional experiences, internships), an essential part of teacher preparation, is suitably built-in into both undergraduate and graduate programs (Franks, 1988).

Franks (1988) also cited the importance of a research component in physical education graduate education, pointing out that the students' program of study should be tailored to suit their research interests. This individualization focuses more on research training and less on actual face-to-face class time. The body of knowledge is the starting point for the program and 
then centered on independent studies (Franks, 1988). Siedentop (1987) stated, "far too often, student queries about what they have to do to complete the program are responded to with lists of course requirements" (p. 84).

One significant observation from Spirduso and Lovett (1987) review of doctoral programs in physical education found graduate programs in physical education was that an assortment of advanced degrees were offered in a variety of schools and specializations varied. The researcher sent a questionnaire to 58 schools listed as doctoral universities in physical education (Massengale \& Sage, 1982). The authors cited a 74\% return rate. Of those returned, 17 were listed as top 20 doctoral programs in physical education (Hasbrook \& Loy, 1983).

Larger schools (more than 20,000 students) tended to offer more highly specialized programs in comparison to smaller counterparts (less than 20,000 students). Some of these specializations include exercise physiology, biomechanics, motor learning, professional preparation, and administration. Smaller colleges tended to house general physical education programs (Spirduso \& Lovett, 1987). The acquisition of skills in sport and exercise and how teachers can assist those skills are the central focus of the field of physical education (Griffey, 1987).

Ward, Parker, Sutherland, and Sinclair (2011) looked at Doctoral programs in PETE (DPETE), specializing only in common themes as a cause for concern: "the narrowness of research preparation, the emphasis on disciplinary silos, the lack of competitiveness and innovation within and beyond academia, and the role of graduate assistants" (p. 145). Ward et al. (2011) collected and assessed syllabi and program documents from 20 programs and conducted interviews with faculty in 24 PETE doctoral programs. Findings on the PETE doctoral curriculum are as follows. 
Core content. Ward et al. (2011) found few consistencies in the core content of the 24 doctoral programs. The depth of the study ranged from specific to courses in which both master's and doctoral students enrolled, and doctoral only classes. Courses focused on teaching research in PE, supervision, and teacher education research. The findings suggested that any possibility of finding a common core centered on teaching effectiveness in PE, which, in the author's opinion is more relevant at the undergraduate level (Ward et al., 2011). Few examined PETE, and only four programs offered classes in supervision. Instead of formal coursework, it should be noted that programs used "classes and seminars on issues and trends to cover topics such as sociocultural issues, sociology, curriculum, and motivation theory” (Ward et al., 2011, p. 151), and only six programs incorporated curriculum classes.

The findings suggest that more than effective teaching in PE should be included in a common core knowledge base of PETE doctoral programs. Education to inform the practice of future teacher educators produced by the programs should be included as well (Ward, et al., 2011). The syllabi examined literature sources used in core classes in PETE doctoral programs. These literature sources also pointed to an area of commonality within PETE doctoral program literature as teaching effectiveness. It should be noted, however, that based on the institution the focus of PETE doctoral study differs significantly.

Research classes. In some instances, programs focused almost exclusively on research skills and offered few opportunities for PETE doctoral students to focus on study beyond research classes. In other cases, research classes halt following introductory statistics courses, and the majority of programs offered both quantitative and qualitative opportunities (Ward et al., 2011). The question posed is how well-equipped doctoral students are to research the degree completion. The issue in need of attention as cited by the authors is the narrow scope of research 
offered in physical education. Seeing how PE has evolved to reflect different beliefs regarding what counts as knowledge, represented by a diverse group of individuals (Ward et al., 2011). Research has evolved from discipline-specific in the 20th century, to cross-disciplinary, multi, and interdisciplinary to connect research relationships of the 21 st century. The terms cross, multi, and interdisciplinary research used by Epton, Payne, and Pearson (1983) describe research relationships that connect to complete one task. The issue of importance in PETE doctoral programs is preparing new faculty to connect this cross-disciplinary research in their careers (Ward et al., 2011).

Beyond the core. Ward et al. (2011) refer to the cognate specialization as work beyond core courses. The most common cognate listed was research. Other areas of specialization include "adapted physical education, curriculum, psychological and sociocultural studies" (Ward et al., 2011, p. 153). PETE doctoral candidates must stay informed of an ever-changing knowledge base.

Scholarship expectations. Scholarship expectation of PETE doctoral students indicated most universities expected publication submissions from students; however, research shows that few of these programs held doctoral students responsible (Ward et al., 2011). Only 2 of the 24 programs required submission of manuscripts for review - the type of publication expected of PETE doctoral students varied from practitioner-based articles to conceptual to data-based articles. Likewise, many programs held students accountable to present at local, state, and national conventions and conferences, with expectations, once again being diverse (Ward et al., 2011).

Additional expectations. In 2015, Boyce Lund, and O’Neil gathered information on DPETE programs. One crucial part of the information as it relates to the present study is 
characteristics of the pedagogy faculty members at the D- PETE institutions: Information gathered pertaining to number of D-PETE faculty members, academic rank, ethnicity, gender, gender by rank, and plans to retire within 5 years (Boyce et al., 2015). The authors surveyed twenty-seven programs in 2005-2006, with approximately 90 D-PETE faculty members across these programs. In 2008-2009, 114 D-PETE faculty members taught in D-PETE programs, with 112 faculty members teaching in D-PETE programs in 2011-2012. The data from 2008 through 2011 reflected both full and part-time appointments, whereas the 2005-2006 survey did not. This inclusion of part-time faculty may have added to the total number of faculty positions in the later data sets.

Faculty academic rank across the six years was relatively similar. Though the percentage of non-Caucasian faculty members did increase from $9 \%$ in 2005 to $11 \%$ in 2011, the lack of diversity remained constant. The gender ratio was relatively evenly split (Boyce et al., 2015). Concerning current D-PETE faculty plans for retirement, the percentage of faculty planning to retire remained practically unchanged from 11.5\% across the six years (Boyce et al., 2015). Many programs required PETE doctoral students to gain teaching experience. Typically, this occurred by teaching undergraduate major courses or basic instruction courses — two of the 24 programs identifying strict strategies to ensure a variety of teaching experiences for PETE doctoral students in a variety of undergraduate settings (Ward et al., 2011). This experience teaching came from experiences as a "graduate assistant, independent study, or volunteer expectation" (Ward et al., 2011, p. 154). All programs offered different amounts of experiences, preparing some students at a higher capacity than others to teach in higher education. However, compared with other fields, doctoral students in PETE are better able to teach in higher education (Golde \& Dore, 2001; Kendall, 2002). Other expectations listed were faculty shadowing, 
involvement in journal clubs, attending conferences, university service, graduate student committees, and grant writing. Undergraduate and doctoral programs in PETE and physical education were discussed in the previous literature. The missing piece of the puzzle is literature regarding the master's degree curriculum in physical education. Standards-based literature in physical education encompasses other disciplines under the physical education/kinesiology umbrella. To date, research outlining the standards-based curriculum in master's in PETE programs is lacking.

\section{Master's Curriculum in Physical Education}

Continuing education programs in kinesiology often present opportunities for career building and development. During master's degree programs, faculty members prepare TCs as competent practicing educators for jobs both before and during their time teaching (Davis \& Hawkins, 2014). Research on master's degrees in other disciplines of education has generated positive results. Master's degrees in the field of study showed a direct relationship between teacher effectiveness in mathematics and an in-field master's degree (Goldhaber \& Brewer, 2000). Likewise, findings from Betts, Zau, and Rice (2003) determined in the subject of reading, student achievement variances only existed if teachers held an in-field advanced degree.

Graduate curriculum research in kinesiology does not limit itself to PETE. Other disciplines under the kinesiology umbrella follow strict sets of standards set forth by governing bodies that serve as the backbone of their curriculum makeup. For example, the National Athletic Trainers Association (NATA) serves as the governing body for athletic training advancement in the United States (Delforge \& Behnke, 1999). The first athletic training curriculum model (1959) covered two essential features directly connected to the employability of athletic trainers in the late 1950s and the 1960s (Delforge \& Behnke, 1999). The two areas of 
emphasis were on the athletic trainer obtaining the qualifications to teach at the secondary level due to the need for athletic trainers on the secondary level. Because of this, the curriculum was intended to prepare the student as both an athletic trainer and high school teacher, predominantly in health/physical education. Athletic training students were required to complete prerequisites for a teaching credential. Their corresponding university outlined the requirements for the teaching credential. The secondary feature of the athletic training curriculum was its attachment to courses defined as prerequisites for the acceptance into schools of physical therapy (PT). PT was encouraged as a way for athletic training students to enhance their studies as a means to enhance professional growth and development, and to increase the likelihood of employability.

During the late 1980s, the start of the initial work that led to pioneering the professional growth and development of athletic training and athletic training education began (Delforge \& Behnke, 1999). Several primary steps associated with accreditation of entry-level athletic training education programs led to AMA recognition. The 1970s saw the analysis of the accreditation of athletic training education programs by an outside agency. This analysis occurred through the works of Sayers Miller, the first chair of the NATA Professional Education Committee (Delforge \& Behnke, 1999). The Education Council had the job of continuing communication with the Committee on Accreditation in March of 1996. The proposal's focus was the approval of advanced graduate athletic education programs, which is currently referred to as "accreditation," with the NATA (Delforge \& Behnke, 1999). As a result of this, the revision, "Standards and Guidelines for the Development and Implementation of NATA Accredited Graduate Athletic Training Education Programs" came about in 1997. This development implemented accreditation of graduate programs. Many graduate-level athletic training programs have been required to transition from the traditional bachelor's degree format 
to a bachelor's/master's degree format as well (Mazerolle, Bowman, \& Pitney, 2015). This transition was a significant planned change in the education and credentialing of athletic trainers to enhance practitioner knowledge and promote the credibility in the healthcare community (Wilkerson, Colston, \& Bogdanowicz, 2006).

Wahl-Alexander \& Curtner-Smith (2018) noted that university undergraduate activity courses in physical education are frequently taught by graduate teaching assistants (GTAs) studying for a master's or doctoral degree in one of the various sub disciplines of Kinesiology. As a result of this, pedagogical preparation of GTA instructors may vary greatly. Additionally, Richards, McLoughlin, Gaudreault, and Ivy (2018) noted the importance placed on recruiting PETE doctoral students who have prior in-service teaching experience. After determining that their undergraduate PETE curriculum was comprised of essential courses, one west coast university answered the call for improved teacher preparation programs by infusing physical education and physical activity leadership into their Master of Arts program (MAT PE-PAL) (Dauenhauer, Krause, Douglas, Smith, Babkes Stellino, \& Carson, 2015; Dauenhauer, Krause, Douglas, Smith, \& Stellino, 2017). This program utilized a hybrid 30-credit format, with online courses undergoing rigorous Quality Matters standards for Online Learning in Higher Education Dauenhauer, Krause, Douglas, Smither \& Stellino, 2017; Quality Matters, 2014).

Components of this PETE master's program focused on four components. The four components were "pedagogical foundation, applied research and evaluation techniques, a broad understanding of the school health environment, and leadership skills", (Dauenhauer, et al., 2017, p 16). Despite this detailed research, one master's program in PETE is the primary focus. After reviewing master's in physical education programs related to advanced standards, research in kinesiology disciplines outside of teacher education exists. It is apparent that little 
research has been completed concerning master's in PETE programs. The bulk of the research that exists concerning the relationship between PETE programs and the national standards has focused on the undergraduate level. There is a need for parallel research at the master's level in PETE.

The master's curriculum in education also serves as a window into best practices in graduate teacher education. Little research exists examining the profile of master's in education programs. Ramsey, Hawkins, Housner, Wiegand, and Bulger (2009), however, aimed to describe and assess the Master of Science program in PETE at West Virginia University in a comprehensive analysis of the blended learning hybrid model (combining courses taught on site with courses taught through web-based distance education). Data collections occurred through an anonymous online survey of members of five graduating cohorts. Furthermore, analyzing standards-based exit portfolios completed by students from one recently graduated class and an independent, external evaluator (Ramsey et al., 2009).

Participants included 70 program graduates who were teaching at K-12 public schools or similar educational settings in 16 different states in the United States. Most respondents (80\%) were teaching physical education at the time of data collection. Few (20\%) were teaching in other subject areas (math, English, health education). About half were teaching at the elementary level, with the remainder in middle and high school settings (Ramsey et al., 2009). Slightly more than half $(55 \%)$ of respondents were female. The following data assessed program effectiveness.

Survey. Participants were asked to complete a survey on the strengths and weaknesses of the Blended Master's Degree (BMD) program and courses, the knowledge, skills, and dispositions gained, and how the program enhanced their achievement and application of 
advanced teaching standards in their teaching (Ramsey et al., 2009). Seventy program graduates were invited to participate. There was a $55 \%$ response rate, with $83 \%$ from the most recent cohorts. The survey included close-ended, multiple response, and open-ended questions, with 30 of those related to the application of professional standards.

Master teacher practicum portfolios. The Master Teacher Practicum course required teachers to present data-based confirmation that each advanced standard had been achieved (Ramsey et al., 2009). Participants were required to align the national standards with courses that throughout the program within their presentations. This culminating experience (portfolio) has always been part of the program, but data for only the most recent cohorts $(N=21)$ judged by faculty and colleagues NASPE/NCATE advanced standards were collected (Ramsey et al., 2009).

One of the most noteworthy points of the WVU BMD is that the program is standardsdriven (Ramsey et al., 2009). A significant part of the survey included 30 standards related questions asking graduates to respond to the degree of application of the standards to their teaching and the WVU BMD programs contribution to this. Results revealed that graduates indicated that the majority $(70 \%)$ applied the standards in their teaching either frequently or intermittently (Ramsey et al., 2009).

To summarize findings from Ramsey et al. (2009), all features of the evaluation supported the blended learning approach, with positive responses from graduates in all aspects of the program, particularly those that helped establish a learning community. Participants made it clear that both online and on-campus components contributed to their learning and application of the advanced standards in their teaching. Participants also indicated that the blended approach was ideal for busy professionals in different locations and promoted a sense of community 
among cohort-mates. Respondents indicated that program coursework could be divided effectively into courses that were more appropriately suited for online versus on-campus instruction.

Student feedback prompted curricular changes as the program expanded. Changes included restructuring of the number of online courses taken at one time, and moving of PET 615, Research Methods, from the on-campus line-up to a fall semester online experience. Changes made to the PET 615 course itself included a stronger focus on assessment and assessment data to sway instructional decisions and changes in statistical use in the course. As a result of the change of PET 615, PET 665, Physical Education Curriculum, was moved to the summer. This summer move allowed students to develop a new curriculum for the upcoming school year based on course content. The changes mentioned above appeared to have benefitted students and enabled the program to address drawbacks related to meeting the NASPE advanced standards dealing with analysis (Ramsey et al., 2009). Lastly, the expansion of the summer timeframe in which face to face courses were offered was investigated as a result of Ramsey at al. (2009) study. The summer experience at the time of this study consisted of two three-credit courses in two weeks, from 9am-5pm nearly every day with additional requirements (homework and group work).

Conversely, open-ended questions indicated that only two weeks on campus proved to be an attractor to students choosing whether to enroll in this blended program.

Respondents indicated that the on-campus portion of the program was critical in promoting a sense of community among learners (Ramsey et al., 2009). The face-to-face interaction with fellow students and faculty served as an enabler of communication and encouragement experienced during the online portion of the program. Social networking, social activities during 
summer sessions, and connections between cohorts all appear to be a valuable aspect of the program. In the 2017 study "Tracking Distance Education in the United States," the Babson Survey Research Group revealed that online student enrollments increased for the 14th straight year in 2016-17, with more than $31 \%$ of all college students taking at least one distance education course - and all evidence suggests the uptick has continued (Seaman, Allen, Seaman, \& Babson Survey Research, 2018; Bednar, 2018).

At the present time, countless students access online educational resources with the use of mobile devices, often substituting this for traditional learning interactions (Anshari, Alas, Sabtu, \& Hamid, 2016). Using online learning has aided professors in increasing efficiency and teaching effectiveness (Puzziferro \& Shelton, 2014; Park \& Lim, 2015). Research by Allen \& Seaman, et al. (2018) shows that over the past two decades, online education is quickly growing. According to the U.S. Department of Education (2013), the number of American college students taking an online course is $32 \%$, and those enrolled in a fully online program is $25 \%$ (Berry, 2018). Expanding and fine tuning this online focus in PETE master's program is critical in recruiting and retaining students. According to Barry (2018) and Ke \& Hoadley (2009), graduate students who feel connected to peers and faculty have a higher likelihood of engaging academics and are less likely to withdraw from the academic program. Retention has been an established issue with distance education (Ramsey et al., 2009). A variety of reasons have been cited, including changes in interest, course structures, struggles with online format, and life changes, (Chacon-Duque, 1987; Chyung, Winiecki, \& Fenner, 1998; Ramsey et al., 2009; Verduin \& Clark, 1991). One of the benefits of blended programs is the establishment of a learning community and the positive effect that it has on alleviating dropout rates. Participants' responses to open-ended questions indicate that they appreciated the support from the cohort members and 
indicated the importance of the learning community within the program. With the implementation of a blended program comes a need to keep up with ever-changing technology and challenges. Results indicated a need for clarity in the online environment, indicating that one or two students have found the online environment challenging.

Ramsey's et al. (2009) study focused on one master of science-PETE program and provides some insight into the perceived value of blended programs (as opposed to blended courses) and the strong function of a program designed to cultivate master teachers (Ramsey et al., 2009). While the study into one blended master's in PETE program at WVU yielded some valuable information about one university and its practices relating the advanced standards to teacher education, further investigation is necessary.

While the quality of undergraduate education in the United States is the foundation of considerable deliberation among lawmakers and education professionals (Arum \& Roksa, 2011), master's degrees receive significantly less consideration (Ott, Baca, Cisneros, \& Bates, 2015). One reason for this may be the lack of attention paid to the accreditation of master's programs. Some institutions evaluate graduate students using common standards for each field of study (Khan, Khalsa, Klose, \& Cooksey, 2012). Past research from experts contradicts this, contending the curriculum and outcomes of graduate students are varied, and assessment procedures must be specific to the differences in disciplines (Dougan, 1996; Dunbar, Brooks, \& Kubicka-Miller, 2006). Graduate expectations should focus on developing the practicing practitioner instead of creating effective notice teachers. Bulger, Illig, and Jones (2017) echo these expectations by outlining three areas of leadership competencies specific to graduate level studies. The three areas, team building and facilitation, capacity building, and program development and 
management differ from undergraduate level leadership competencies focusing on content knowledge and knowledge of instructional practice (Bulger et. al, 2017).

Additionally, the background and experience of faculty teaching in master's in PETE programs, demographics, required culminating experiences, and their relationship to the SHAPE America advanced standards for PETE is necessary to offer a more precise overall description of master's in PETE programs in the United States.

\section{Summary}

It becomes necessary to align instruction with standards to safeguard clear and precise goals for TCs. Standards ensure accountability and hold instructors responsible for curriculum content and presentation of that content. Standards-based instruction helps guide the design, application, and assessment of TC learning. Expectations for TCs should be planned to align with each prearranged standard.

Advanced standards intend to align with programs offering post-secondary licensure (master's degree). SHAPE America has outlined three advanced standards with four underlying principles to serve as the guiding framework for institutions offering a master's degree in PETE. Analysis of PETE undergraduate programs yielded valuable information concerning the structure and content of undergraduate programs, instructor and student profile, and alignment of programs to SHAPE America's initial standards for teacher training. Further investigation on the doctoral level indicates a more in-depth knowledge of structure of D-PETE and undergraduate programs in the United States. Based on research, D-PETE studies indicate that more significant attention to advanced degrees in PETE is necessary.

Lastly, research exists for physical education programs falling under the kinesiology umbrella (e.g. athletic training) and their relationship to program structure and the application of 
program standards. Little research concerning the application of SHAPE America's advanced standards for master's in PETE programs has been completed. One study by Ramsey et al. (2009) paved the way by analyzing the blended PETE master's program at one institution. However, this is a small piece of the overall picture of master's in PETE programs in the United States. Further research must be completed to understand program delivery (online, blended, face to face instruction), instructor background, admission requirements, culminating experience requirements, and the programs' application of the SHAPE America advanced standards. 


\section{References}

Alcorn, N. (1999). Teacher education in New Zealand: Policy and practice since 1948. New Zealand Journal of Educational Studies, 34, 110-120.

Allen, I. E., \& Seaman, C. A. (2007). Likert scales and data analyses. Quality progress, 40(7), 64-65.

Anonymous. (2014). What current issues and topics should be embedded within a physical education teacher education (PETE) curriculum? Journal of Physical Education, Recreation and Dance, 85(8), 47-48.

Anshari, M., Alas, Y., Sabtu, N. P. H., \& Hamid, M. S. A. (2016). Online learning: Trends, issues and challenges in the big data era. Journal of e-Learning and Knowledge Society, 12(1).

Armour, K. M., \& Yelling, M. (2007). Effective professional development for physical education teachers: The role of informal, collaborative learning. Journal of Teaching in Physical Education, 26(2), 177-200.

Armour, K. (2014). New directions for research in physical education and sport pedagogy. Sport, Education \& Society, 19(7), 853-854. 
Arum, R., \& Roksa, J. (2011). Academically adrift: Limited learning on college campuses. Chicago, IL: University of Chicago Press.

Ary, D., Jacobs, L., Sorensen, C., \& Walker, D. (2013). Introduction to research in education. Boston: Cengage Learning.

Assess Teaching and Learning-Teaching Excellence and Educational Innovation- Carnegie Mellon University. (n.d.). Retrieved May 25, 2015 from http://www.cmu.edu/teaching/assessment/index.html

Ayers, S.F., \& Woods, A.M. (2019). Chapter 5: Recruitment in PETE: Survey results and discussion. Journal of Teaching in Physical Education, 28(1), 37-44.

Ayers, S. F., \& Housner, L. D. (2008). A descriptive analysis of undergraduate PETE programs. Journal of Teaching in Physical Education, 27(1), 51.

Bagley, S. S., \& Margolis, J. (2018). The Emergence and Failure to Launch of Hybrid Teacher Leadership. International Journal of Teacher Leadership, 9(1), 33-46.

Bahneman, C. P. (1996). An analysis of the undergraduate physical education teacher certification requirements within institutions that offer a doctoral degree in physical education. Physical Educator, 53(4), 198-202.

Ball, D. L., \& Cohen, D. K. (1999). Developing practice, developing practitioners: Toward a practice-based theory of professional education. Teaching as the learning profession: Handbook of policy and practice, 1, 3-22.

Ball, D. L., \& Forzani, F. M. (2009). The work of teaching and the challenge for teacher education. Journal of Teacher Education, 60(5), 497-511. 
Banville, D., White, C. S., \& Fox, R. K. (2014). Teacher development during advanced master's coursework and impact on their learning one year later. Physical Educator, 71(4), 558579.

Barge, J. (2013). Why is professional knowledge a necessary component of an effective classroom? Retrieved November 19, 2015, from http://www.cobbk12.org/centraloffice/hr/cobbkeys/QG_TeachersStandard01.pdf

Bates, T., Swennen, A., \& Jones, K. (2014). The professional development of teacher educators. London: Routledge.

Bednar, J. (2018). Screen test: Why is online learning seeing a surge in popularity? Businesswest, 34(26), 32 .

Berliner, D. C. (1994). Expertise: The wonder of exemplary performances. In J. Mangieri \& C. Block (Eds.), Creating powerful thinking in teachers and students: Diverse perspectives. Fort Worth, TX: Harcourt Brace.

Berry, S. (2018). Building community in an online graduate program: Exploring the role of an in-person orientation. The Qualitative Report, 23(7), 1673-1687.

Betts, J. R., Zau, A., \& Rice, L. (2003). Determinants of student achievement: New evidence from San Diego. San Francisco, CA: Public Policy Institute of California.

Boyce, B.A., \& Rikard, G.L. (2011). Characteristics of PETE doctoral level institutions: Descriptions of programs, faculty, and doctoral students. Journal of Teaching in Physical Education, 30(2), 103-115.

Boyce, B. A., Lund, J., \& O'Neil, K. (2015). PETE doctoral institutions: Programs, faculty, and doctoral students. Research Quarterly for Exercise \& Sport, 86(3), 311-318. 
Bohmer, M., Glock, S., \& Krolak-Schwerdt, S. (2014). Teachers' professional development: Assessment, training, and learning. Rotterdam, Netherlands: Sense Publishers.

Brown, B. (1983). Standards-based education reform in the United States since "A Nation at Risk.” Retrieved November 15, 2015 from: http://www.hawaii.edu/hepc/pdf/Reports/FINAL-History_of_StandardsBased_Education_Reform.pdf

Bulger, S., Illig, K., \& Jones, E. (2017). Achieving alignment in the preparation of CSPAP leaders in PETE programs. Journal of Physical Education, Recreation \& Dance, 88(2), $37-42$.

Bulger, S.M., Braga, L., DiGiacinto, K., \& Jones, E.M. (2016). Student recruitment and retention efforts in PETE: Cloudy skies of silver linings. Journal of Physical Education, Recreation \& Dance, 87(8), 34-41.

Bulger, S. M., Housner, L. D., \& Lee, A. M. (2008). Curriculum alignment: A view from physical education teacher education. Journal of Physical Education, Recreation \& Dance, 79(7), 44-49.

Bullock, S. M. (2011). Inside teacher education: Challenging prior views of teaching and learning. New York: Springer Science \& Business Media.

Butler, J. (2006). NASPE/NCATE report preparation for the accreditation process. Journal of Physical Education, Recreation \& Dance, 77(2), 15-19, 31-32.

Chacon-Duque, F. J. (1987). A multivariate model for evaluation distance higher education. College Park, PA: Pennsylvania State University Press.

Cherubini, L. (2008). Teacher candidates' perceptions of principal and teacher leadership: A functional disconnect. Leadership Review, 55(2), 80-101. 
Chyung, Y., Winiecki, D. J., \& Fenner, J. A. (1998). A case study: Increase enrollment by reducing dropout rates in adult distance education. Retrieved October 21, 2015 from http://www.uwex.edu/disted/conference/resource_library/proceedings/01_6.pdf

Clark, C. M., \& Peterson, P. L. (1986). Teachers' thought processes. In M. C. Wittrock (Ed.), Handbook of research on teaching (pp 3-129). New York: MacMillan.

Corbin, C. B. (1994). Current status of HPER in the United States. In P. Duffy \& L. Dugdale (Eds.), HPER-Moving toward the 21st century (pp. 313-325). Champaign, IL: Human Kinetics.

Council for the Accreditation of Education Professionals. (2008). Professional standards for the accreditation of teacher preparation institutions. Retrieved on August 15, 2015, from http://www.ncate.org/public/standards.asp?ch=4

Danielson, C. (2006). Teacher leadership that strengthens professional practice. Alexandria, VA: ASCD.

Darling-Hammond, L. (2008). Powerful teacher education: Lessons from exemplary programs. New York: John Wiley \& Sons.

Dauenhauer, B., Krause, J., Douglas, S., Smith, M., \& Stellino, M.B. (2017). A newly revised master's degree in physical education and physical activity leadership at the University of Northern Colorado. Journal of Physical Education, Recreation \& Dance, 88(2), 14-19.

Dauenhauer, B., Krause, J., Douglas, S., Smith, M., Babkes Stellino, M., \& Carson, R. L. (2015). Development of a master's program related to CSPAP leadership: Perspectives from UNC. Session presented at the Health and Physical Education Teacher Education Conference, Atlanta, GA. 
Davis, W. J., \& Hawkins, A. (2014). An exploration of master's degree field study and teacher and student behavior in physical education. Global Journal of Health \& Physical Education Pedagogy, 3(3), 179-200.

Day, C., Gu, Q. (2007). Variations in the conditions for teachers' professional learning and development: Sustaining commitment and effectiveness over a career. Oxford Review of Education, 33(4), 423-443.

Deglau, D., \& O'Sullivan, M. (2006). The effects of a long-term professional development program on the beliefs and practices of experienced teachers. Journal of Teaching in Physical Education, 25(4), 379-396.

Delforge, G. D., \& Behnke, R. S. (1999). The history and evolution of athletic training education in the United States. Journal of Athletic Training, 34(1), 53.

Denscombe, M. (2014). The good research guide: For small-scale social research projects. United Kingdom: McGraw-Hill Education.

Dillman, D. A., Smyth, J. D., \& Christian, L. M. (2009). Mail and internet surveys: The tailored design method (3rd ed.). New York: John Wiley and Sons.

Dillman, D. A. (2011). Mail and Internet surveys: The tailored design method--2007 Update with new Internet, visual, and mixed-mode guide. New York: John Wiley \& Sons.

Dixon, H., \& Ward, G. (2015). The value of master's study to teachers' professional practice: Contradictory discourses within the workplace. Australian Journal of Teacher Education, 40(2), 52.

Dougan, A. M. (1996). Student assessment by portfolio: One institution’s journey. The History Teacher, 29(2), 171-178. 
Dunbar, N., Brooks, C., \& Kubicka-Miller, T. (2006). Oral communication skills in higher education: Using a performance-based evaluation rubric to assess communication skills. Innovative Higher Education, 31(2), 115-128.

Dyson, B. (2014). Quality physical education: A commentary on effective physical education teaching. Research Quarterly for Exercise \& Sport, 85(2), 144-152.

Easton, L. (2008). From professional development to professional learning. Phi Delta Kappan, 89(10), 755-759, 761.

Epton, S.R., Payne, R.L., \& Pearson, A.W. (1983). Managing interdisciplinary research. Chichester, England: John Wiley \& Sons.

Ennis, C. (2014). The role of students and content in teacher effectiveness. Research Quarterly for Exercise and Sport, 85, 6-13.

Enright, E. \& O’Sullivan, M. (2012). Physical education in all sorts of corners: Student activists transgressing formal physical education curricular boundaries. Research Quarterly for Exercise and Sport 83(2): 255-267.

Ensign, J., Woods, A.M., \& Hodges, Kulinna, P. (2017). Teacher development in first year physical educators: A comparison of effectiveness among different physical education teacher education backgrounds. Journal of Teaching in Physical Education, 36(4), 455466.

Erwin, H., Beets, M. W., Centeio, E., \& Morrow Jr, J. R. (2014). Best practices and recommendations for increasing physical activity in youth. Journal of Physical Education, Recreation and Dance, 85(7), 27-34. 
Estes, S. (1994). Knowledge and kinesiology. Quest, 46(4) 392-409.

Fairman, J., Mackenzie, S. (2015). How teacher leaders influence others and understand their leadership. International Journal of Leadership in Education, 18(1), 61-87.

Fenstermacher, G. D. (1994). The knower and the known: The nature of knowledge in research on teaching. Review of Research in Education, 20(1), 3-56.

Fowler Jr., F. J. (2013). Survey research methods. Washington, D.C.: Sage Publications.

Francis, J. J., Johnston, M., Robertson, C., Glidewell, L., Entwistle, V., Eccles, M. P., \& Grimshaw, J. M. (2010). What is an adequate sample size? Operationalizing data saturation for theory-based interview studies. Psychology \& Health, 25(10), 1229-1245.

Franks, B. D. (1988). Thoughts about graduate study in physical education, exercise, and sport science. Quest, 40(1), 56-62.

Gibbs, G. R. (2018). Analyzing qualitative data (Vol. 6). Newbury Park, CA: Sage.

Goc Karp, G., Brown, H., Scrugges, P.W., \& Berei, C. (2017). Cultivating leadership, pedagogy and programming for CSPAP and healthy, active lifestyles at the University of Idaho. Journal of Physical Education, Recreation \& Dance, 88(1), 29-35.

Golde, C. M., \& Dore, T. M. (2001). At cross purposes: What the experiences of today's doctoral students reveal about doctoral education. Retrieved September 21, 2015 from http://www.phdcompletion.org/promising/Golde.pdf

Goldhaber, D. D., \& Brewer, D. J. (2000). Does teacher certification matter? High school teacher certification status and student achievement. Educational Evaluation and Policy Analysis, $22(2), 129-145$.

Goodwin, A. L., Smith, L., Souto-Manning, M., Cheruvu, R., Tan, M. Y., Reed, R., \& Taveras, L. (2014). What should teacher educators know and be able to do? Perspectives from practicing teacher educators. Journal of Teacher Education, 65(4), 284-302. 
Griffey, D. C. (1987). Trouble for sure a crisis—perhaps: Secondary school physical education today. Journal of Physical Education, Recreation \& Dance, 58(2), 20-21.

Groves, R. M., Fowler Jr, F. J., Couper, M. P., Lepkowski, J. M., Singer, E., \& Tourangeau, R. (2011). Survey methodology (Vol. 561). New York: John Wiley \& Sons.

Hammer, D., Piascik, P., Medina, M., Pittenger, A., Rose, R., Creekmore, F., \& Scott, S. (2010). Recognition of teaching excellence. American Journal of Pharmaceutical Education, 74(9) 41-44.

Hargreaves, A., \& Fink, D. (2006). Sustainable leadership (Vol. 6). New York: John Wiley \& Sons.

Hasbrook, C.A., \& Loy, J.W. (1983). Assessment of doctoral programs in physical education: Reports, rankings, and recommendations. Quest, 35(2), 131-144.

Hetland, K. M., \& Strand, B. (2010). A descriptive analysis of undergraduate PETE programs in the central district. ICHPER-SD Journal of Research, 5(1), 3-9.

Hill, G., \& Brodin, K. L. (2004). Physical education teachers' perceptions of the adequacy of university coursework in preparation for teaching. Physical Educator, 61(2), 75.

Hooper, T., \& Butler, J. (2013). Complexity thinking in physical education: Reframing curriculum, pedagogy, and research. London: Routledge.

Hord, S. M., \& Southwest Educational Development Lab., A. T. (1997). Professional learning communities: Communities of continuous inquiry and improvement. Retrieved September 22, 2015 from http://files.eric.ed.gov/fulltext/ED410659.pdf

Horng-Yi, L. (2014). Inquiry-based teaching in second and foreign language pedagogy. Journal of Language Teaching \& Research, 5(6), 1236-1244. 
Housner, L. D. (1996). Innovation and change in physical education. (pp. 367-390). Student learning in physical education: Applying research to enhance instruction. Champaign, IL: Human Kinetics.

Huba, M. E., \& Freed, J. E. (2000). Learner centered assessment on college campuses: Shifting the focus from teaching to learning. Community College Journal of Research and Practice, 24(9), 759-766.

Israel, G. D. (2011). Strategies for obtaining survey responses for extension clients: Exploring the role of e-mail requests. Journal of Extension [Online], 49(3) Retrieved September 21, 2015. http://www.joe.org/joe/2011june/a7.php

Jin, H., Shin, H., Johnson, M. E., Kim, J., \& Anderson, C. W. (2015). Developing learning progression-based teacher knowledge measures. Journal of Research in Science Teaching, 52(9), 1269-1295.

Ke, F., \& Hoadley, C. (2009). Evaluating online learning communities. Educational Technology Research and Development, 57(4), 487-510.

Keegan, R. (2016). Action research as an agent for enhancing teaching and learning in physical education: A physical education teacher's perspective. The Physical Educator, 73(2), 255-284.

Khan, R., Khalsa, D., Klose, K., \& Cooksey, Y. (2012). Assessing graduate student learning in four competencies: Use of a common assignment and a combined rubric. Research and Practice in Assessment. 7(12), 29-41.

Kendall, G. (2002). The crisis in doctoral education: A sociological diagnosis. Higher Education Research \& Development, 21, 131-139. 
Korthagen, K., Loughran, J., \& Lunenberg, M. (2005). Teaching teachers-Studies into the expertise of teacher educators: An introduction to this theme issue. Teaching and Teacher Education, 21, 107-115.

Kretchmar, R. (2000). Movement subcultures: Sites for meaning. Journal of Physical Education Recreation \& Dance 71(5): 19-25.

Kvale, S., \& Brinkmann, S. (2009). Interviews: Learning the craft of qualitative research interviewing. Washington D.C.: Sage.

Lampert, M., \& Graziani, F. (2009). Instructional activities as a tool for teachers and teacher educators' learning. The Elementary School Journal, (109)5, 492-509.

Landi, D., Fitzpatrick, K., \& McGlashan, H. (2016). Models based practices in physical education: A sociocritical reflection. Journal of Teaching in Physical Education, 35(4), 400.

Lenske, G., Thillmann, H., Wirth, J., Dicke, T., \& Leutner, D. (2015). Pedagogical professional knowledge of teachers. Review of Education. (8)2, 225-235.

Lewin, K. (1946). Action research and minority problems. Journal of Social Issues, 2(4), 34-46.

Lombard, M., Snyder-Duch, J., \& Bracken, C. C. (2002). Content analysis in mass communication: Assessment and reporting of intercoder reliability. Human Communication Research, 28(4), 587-604.

Lund, J., \& Tannehill, D. (2010). Evaluating your physical education curriculum (57-84). Standards-based physical education curriculum development. Burlington, MA: Jones and Bartlett Learning. 
Maass, K., \& Engeln, K. (2018). Effects of scaled-up professional development courses about inquiry-based learning on teachers. Journal of Education and Training Studies, 6(4), 116.

Makopoulou, K., \& Armour, K. (2014). Possibilities and challenges in teachers' collegial learning. Educational Review, 66(1), 75-95.

Massengale, J.D., \& Sage, G.H. (1982). Departmental prestige and career mobility patterns of college physical educators. Research Quarterly for Exercise and Sport, 53(4), $305-312$.

Mawer, M. (2014). Effective teaching of physical education. London: Routledge.

Mazerolle, S. M., Bowman, T. G., \& Pitney, W. A. (2015). Multistakeholder perspectives on the transition to a graduate-level athletic training educational model. Journal of Athletic Training, 50(9), 964-976.

McArdle, F. A. (2010). Preparing quality teachers: Making learning visible. Australian Journal of Teacher Education, 35(8), 60-78.

McKenzie, T. L., \& Lounsbery, M. A. F. (2013). Physical education teacher effectiveness in a public health context. Research Quarterly for Exercise and Sport, 84, 419-430.

Metzler, M.W. (2014). Teacher effectiveness research in physical education: The future isn't what it used to be. Research Quarterly for Exercise and Sport, 85(1), 14-19.

Miles, M., B., \& Huberman, A., M. (1994). Qualitative data analysis. Thousand Oaks, CA: Sage Publications.

Moon, J. A. (2013). Reflection in learning and professional development: Theory and practice. London: Routledge. 
Mosston, M., \& Ashworth, S. (2002). Teaching Physical Education (5th ed.). San Francisco: Benjamin Cummings.

Mounce, M. T. (2015). A descriptive study of intercollegiate athletics in North Carolina's public community and technical colleges. Mississippi State University.

Murray, J., \& Male, T. (2005). Becoming a teacher educator: Evidence from the field. Teaching and Teacher Education, 21, 125-142.

Attracting and retaining teachers: A question of motivation. Educational Management Administration \& Leadership, 37(5), 574-599.

Nappi, J. S. (2014). The teacher leader: improving schools by building social capital through shared leadership. Principal's Research Review, 9(6), 1-6.

National Association for Sport and Physical Education. (1987b). NASPE/ NCATE Physical Education Guidelines. Reston, VA,

National Association for Sport and Physical Education. (1989). NASPE/ NCATE Physical Education Guidelines (2nd ed.). Reston, VA.

National Association for Sport and Physical Education. (1992a). NASPE/ NCATE Physical Education Guidelines (3rd ed.). Reston, VA.

National Association for Sport and Physical Education. (2001). Initial physical education program report manual, including: NASPE/NCATE 2001 Initial Physical Education Standards (5th ed.). Reston, VA.

National Association for Sport and Physical Education. (2003). National Standards for Beginning Physical Education Teachers (2nd ed.). Reston, VA. 
National Association for Sport and Physical Education (2007). What constitutes a highly qualified physical education teacher? Retrieved August 15, 2008, from http://www.aahperd.org/naspe/pdf_files/HiQualified.pdf

National Association for Sport and Physical Education. (2008). PE Metrics: Assessing the national standards. Reston, VA.

National Association for Sport and Physical Education. (2009). National Standards and Guidelines for Physical Education Teacher Education (3rd ed.). Reston, VA.

National Commission on Excellence in Education. (1983). A nation at risk: The imperative for educational reform. Washington, DC: National Commission on Excellence in Education. Retrieved September 12, 2015, from http://www.ed.gov/pubs/NatAtRisk/risk.html

Neuendorf, K.A., 2002. The content analysis guidebook. Thousand Oaks, CA: Sage.

Nudrat, F., \& Akhtar, M. S. (2014). Assessing potential for teacher leadership: The case of prospective teachers. Journal of Research \& Reflections in Education, 8(2), 105-115.

O'Connor, J., Jeanes, R., \& Alfrey, L. (2016). Authentic inquiry-based learning in health and physical education: A case study of revolutionary practice. Physical Education \& Sport Pedagogy, 21(2), 201-216.

O'Sullivan, M. (1990). Physical education teacher education in the United States. Journal of Physical Education, Recreation \& Dance, 61(2), 41-45.

Ott, M., Baca, E., Cisneros, J., \& Bates, E. (2015). A competency-based approach to the master's degree preparation of higher education professionals. Journal of Case Studies in Accreditation and Assessment, 4,1 .

Paolini, A. (2015). Enhancing teaching effectiveness and student learning outcomes. The Journal of Effective Teaching, 15(1) 20-33. 
Park, Y., \& Lim, K. (2015), Effects of environmental and human constructs on e-learning effectiveness in online university settings. Indian Journal of Science and Technology, 8(S1), 103-109.

Parker, M., Patton, K., Madden, M., \& Sinclair, C. (2010). From committee to community: the development and maintenance of a community of practice. Journal of Teaching in Physical Education, 29(4), 337-357.

Petrie, K., \& McGee, C. (2012). Teacher professional development: Who was the learner? Australian Journal of Teacher Education, 37(2), 59-72.

Patton, M. (2002). Qualitative evaluation and research methods. Thousand Oaks, CA: Sage Publications.

Perda, D. (2013). Transitions into and out of teaching: A longitudinal analysis of early career teacher turnover (Unpublished doctoral dissertation). University of Pennsylvania, Philadelphia.

Poekert, P., Alexandrou, A., \& Shannon, D. (2016). How teachers become leaders: An internationally validated theoretical model of teacher leadership development. Research in Post-Compulsory Education, 21(4), 307-329.

Puzziferro, M., \& Shelton, K. (2014), A model for developing high-quality online courses: Integrating a systems approach with learning theory. Journal of Asynchronous Learning Networks, 12, 119-136.

Quality Matters. (2014). Quality matters higher education rubric (5th ed.). Retrieved from https://www.qualitymatters.org/rubric 
Ramsey, C., Hawkins, A., Housner, L., Wiegand, R., \& Bulger, S. (2009). Finding the recipe for the best blend: The evolution and assessment of a blended master's degree program. Journal of the Research Center for Educational Technology, 5(2), 3.

Richards, K.R., McLoughlin, G.M., Gaudreault, K.L., \& Ivy, V.N. (2018). Perceptions of the physical education doctoral experience: Does previous teaching experience matter? The Physical Educator, (2), 255.

Richards, K.A.R., Gaudreault, K.L., Simonton, K.L., \& Simonton, A. (2018). Physical education graduate student socialization in a research-focused master's program. Journal of Teaching in Physical Education, 37(4), 373-382.

Rink, J. E., French, K. E., Lee, A. M., Solomon, M. A., \& Lynn, S. K. (1994). A comparison of pedagogical knowledge structures of preservice students and teacher educators in two institutions. Journal of Teaching in Physical Education, 13(2), 140.

Rink, J. (2007). What knowledge is of most worth? Perspectives on kinesiology from pedagogy. Quest, 59(1), 100-110.

Rink, J. E. (2013). Measuring teacher effectiveness in physical education. Research Quarterly for Exercise and Sport, 84, 407-418.

Rink, J. (2014). Teacher effectiveness in physical education--consensus? Research Quarterly for Exercise and Sport, 85(3), 282-286.

Schempp, P. G., Manross, D., Tan, S. K., \& Fincher, M. D. (1998). Subject expertise and teachers' knowledge. Journal of Teaching in Physical Education, 17(3), 342-356.

Schon, D.A. (1987). Educating the reflective practitioner: Toward a new design for teaching and learning in the professions. San Francisco: Jossey-Bass. 
Seaman, J. E., Allen, I. E., Seaman, J., \& Babson Survey Research, G. (2018). Grade Increase: Tracking Distance Education in the United States. Babson Survey Research Group.

Sharpe, T., \& Hawkins, A. (1992). Field systems analysis: A tactical guide for exploring temporal relationships in classroom settings. Teaching and Teacher Education, 8(2), 171186.

Shulman, L. (1987). Knowledge and teaching: Foundations of the new reform. Harvard Educational Review, 57(1), 1-23.

Shulman, L. S. (2004a). Those who understand: Knowledge growth in teaching. Educational Researcher, 15(2), 4-14.

Shulman, L. (2004b). Knowledge and teaching: Foundation of the new reform. In L. Shulman and S. M. Wilson (Eds.), The Wisdom of Practice: Essays on Teaching, Learning and Learning to Teach (pp. 217-248). San Francisco: Jossey-Bass.

Shulman, L. (2004c). Disciplines of inquiry in education. In L. Shulman \& S. M. Wilson (Eds.), The wisdom of practice: Essays on teaching, learning and learning to teach (p. 276-307). San Francisco: Jossey-Bass.

Shulman, L. (2013). Those who understand: knowledge growth in teaching. Journal of Education, 193(3), 1-11.

Siedentop, D. (1987). Going public: Quality control in graduate education. Quest, 39, 82-87.

Siedentop, D., \& Locke, L. (1997). Making a difference for physical education; What professors and practitioners must build together. Journal of Physical Education, Recreation \& Dance, 68(4), 25-33.

Silverman, D. (Ed.). (2010). Qualitative research. New York: Sage. 
Society of Health and Physical Educators (SHAPE America). (2015). Retrieved September 20, 2015, from http://www.americankinesiology.org/affiliated-associations/affiliatedassociations/national-association-of-sport-and-physical-education-naspe

Society of Health and Physical Educators (SHAPE America). (2014). National standards and grade-level outcomes for K-12 physical education. Champaign, IL: Human Kinetics.

Sparks, D. (2003). Change agent. Journal of Staff Development, 24(1), 55.

Spirduso, W. W., \& Lovett, D. J. (1987). Current status of graduate education in physical education: Program demography. Quest, 39(2), 129-141.

Stein, L. (2014). Leadership: The teacher's imperative. Journal of Leadership Education, 13(2), 162-168.

Sundaresan, N., Dashoush, N., \& Shangraw, R. (2017). Now that we're “well rounded," let's commit to quality physical education assessment. Journal of Physical Education, Recreation \& Dance, 88(8), 35-38.

Taliaferro, A. R., Ayers, S. F., \& Housner, L. (2017). A descriptive analysis of the application of PETE standards. Physical Educator, 74(4), 606-626.

Taylor- Powell E. Analyzing Qualitative Data. University of Wisconsin Cooperative Extension, 2004. Retrieved March 5, 2016 from: http://learningstore.uwex.edu/pdf/G3658-12.PDF

Tinning, R. (2006). Physical education, curriculum and culture: Critical issues in the contemporary crisis. London: Routledge.

U. S. Department of Education. (2013). The condition of education 2011. Washington, DC: National Center for Education Statistics.

Verduin, J., \& Clark, T. (1991). Distance education: The foundations of effective practice. San Francisco, CA: Jossey-Bass. 
Wahl-Alexander, Z., \& Curtner-Smith, M.D. (2018). Influence of negotiations on graduate teaching assistants' instruction within university activity courses. Journal of Teaching in Physical Education, 37(2), 164.

Ward, P., Parker, M., Sutherland, S., \& Sinclair, C. (2011). A critical examination of the curriculum of physical education teacher education doctoral programs. Journal of Teaching in Physical Education, 30(2), 145-156.

Ward, P. (2013). The role of content knowledge in conceptions of teaching effectiveness in physical education. Research Quarterly for Exercise and Sport, 84(4), 431-440.

Wiegand, R. L., Bulger, S. M., \& Mohr, D. J. (2004). Curricular issues in physical education teacher education. Journal of Physical Education, Recreation \& Dance, 75(8), 47-55.

Wilkerson, G.B., Colston, M.A., \& Bogdanowicz, B.T. (2006) Distinctions between athletic training education programs at the undergraduate and graduate levels. Athletic Training Education Journal, 1(2), 38-40.

Wenner, J. A., \& Campbell, T. (2017). The theoretical and empirical basis of teacher leadership: A review of the literature. Review of Educational Research, 87(1), 134-171.

World Health Organization. (2004). How to investigate the use of medicines by consumers. Geneva: WHO.

Wright, C. (2015). What's next with ESSA? Retrieved from http://commu nity.shapeamerica.org/blogs/carly-braxton/2015/12/23/whats-next- with-essa

Yin, R. K. (2013). Case study research: Design and methods. Washington, D.C.: Sage publications.

York-Barr, J., \& Duke, K. (2004). What do we know about teacher leadership? Findings from two decades of scholarship. Review of Educational Research, 74(3), 255-316. 
Zhang, Z., Gu, X., Zhang, T., Keller, J., \& Chan, S. (2018). Comprehensive school physical activity programs: Recommendations for physical education teacher education. Journal of Physical Education, Recreation \& Dance, 89(5), 11-18.

Zieff, S. G., Lumpkin, A., Guedes, C., \& Eguaoje, T. (2009). NASPE sets the standard: 35 years of national leadership in sport and physical education. Journal of Physical Education, Recreation \& Dance, 80(8), 46-49.

Zimmerman, T., \& Nimon, K. (2017). The Online Student Connectedness Survey: Evidence of Initial Construct Validity. International Review of Research in Open and Distributed Learning, 18(3), 25-46. 


\section{Appendix B}

Initial Email to Identify Participants; Preliminary Work

To Whom It May Concern,

I hope that this email finds you well. My name is Jamie Gilbert, and I am a doctoral student in the College of Physical Activity and Sport Sciences at West Virginia University. I'm completing a doctorate in Kinesiology under the guidance of co-chairs Dr. Sean Bulger and Dr. Valerie Wayda. I am also a teaching faculty member at Indiana University of Pennsylvania.

The focus of my dissertation will be describing Master's in Physical Education programs with an emphasis in Physical Education Teacher Education (PETE) and their relationship to SHAPE America's Advanced Standards. This is an extension of Ayres and Housner's (2008) Descriptive Analysis of Undergraduate PETE programs.

You have been contacted because your university appeared in the database search for Health and Physical Education programs. I just need a little more clarification about your program so please take a moment to answer the following three questions in a reply to this email; your participation is greatly appreciated.

If the answer to (a.) is NO, please reply NO only: This will be the extent of input needed. If you are not the correct contact person, please forward this email to another individual better suited to provide information. Should you have questions, please feel free to reply to this email, as I am happy to help in any way that I can. Your participation is greatly appreciated. Thank you for your time and consideration.

Please answer the following in a reply to this email:

a. Does your institution offer a master's degree in physical education with an emphasis in PETE? If NO, please reply $N O$ and disregard this email.

\section{$\underline{\text { b. Name of Institution }}$}

c. Name/contact email of the contact person for the master's degree in physical education with an emphasis in PETE contact.

Sincerely,

Jamie Gilbert 


\title{
Appendix C
}

\author{
Email to Participants (Consent Letter): Survey
}

Dear

I hope that this email finds you well. My name is Jamie Gilbert. You may remember me from initial contact in January in regard to university offering a master's program with an emphasis in PETE. I am a doctoral student in the College of Physical Activity and Sport Sciences at West Virginia University completing a doctorate in Kinesiology under the guidance of co-chairs Dr. Sean Bulger and Dr. Valerie Wayda. I am also a teaching faculty member at Indiana University of Pennsylvania.

The focus of my dissertation is to describe master's degree programs with an emphasis in Physical Education Teacher Education (PETE) and their adherence to SHAPE America's advanced standards. Your participation in this study is voluntary. Should you agree to participate, an optional interview portion will serve as a follow-up. By participating in this research, an executive summary of results regarding master's programs with an emphasis in PETE will be provided to you and submitted for publication.

Your participation in a survey to gather additional information specific to your program is important in compiling robust data describing master's work in PETE. A link to the survey is included in the conclusion of this email.

Should you have questions, please feel free to reply to this email, as I am happy to help in any way that I can. Your participation is greatly appreciated. Thank you for your time and consideration.

Sincerely,

Jamie Gilbert 


\section{Appendix D}

Survey

Qualtrics Link to Survey: https://qtrial2013.qualtrics.com/SE/?SID=SV 3IPp4Xjt0K7CZil

See Attached Appendix D for full survey in Web Layout 


\section{Program Information}

Please fill out the following demographic information:

Institution Name:

Contact's Name:

Address:

City/Town:

State:

ZIP:

Contact's Email Address:

Does your Institution/University offer a Master's in PETE program?

- Yes

- No

○ NO ends the survey, YES directs to the following items:

Where is your Master's in PETE program located administratively?

- College/School of Education

- Department of Kinesiology/Physical Education

- College/School of Sport/Exercise Science

- Other

○ Specify Other:

Which degree(s) does your Master's in PETE program award?

- M.Ed.

- MA

- MS

- Other

○ Specify Other:

$\underline{\text { Is full time enrollment a requirement? }}$

- Yes

- No 
Program Delivery: The ENTIRE CURRICULUM of your master's in PETE program is delivered (taught):

- Fully on campus

○ If yes, skip to credit hours**

- Blended/Hybrid (Partly online, and partly on campus)

- Fully online

What percentage of curriculum is OFFERED online?

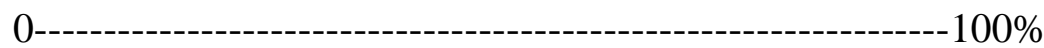

Identify the number of credit hours required to complete your master's in PETE program.

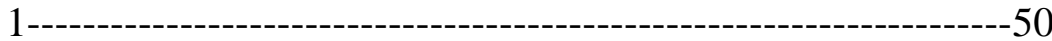

Does your Master's in PETE program follow or emphasize a specific curricular model?

- Yes

- No

- If No, skip to Admission Requirements

Please identify the curricular models emphasized in your PETE program:

- Adventure/Outdoor Education

- Health Related Fitness

- Integrated

- Movement Education

- Personal and Social Responsibility

- Sport Education

- Teaching Games for Understanding

- Other:

○ Specify Other:

\section{ADMISSION REQUIREMENTS}

Is initial teaching licensure (teacher certification) required for program admission?

- Yes, in physical education

- Yes, in any discipline of education

- No 
. Please identify all requirements for admission into your PETE program:

- GRE

- Letters of Recommendation

- General Education Credit Hours

- Initial Teacher Licensure

- Interview

- PRAXIS scores

- Bachelor's Degree

- Transcripts

- Other

○ Specify Other:

\section{PETE Master's Program, Faculty Information}

Please identify the number of Master's in PETE faculty who identify as:

- Male:

- Female:

Please identify the number of FULL TIME PETE FACULTY who identify as:

- African American

- Hispanic

- Asian

- European

- Native American

- Pacific Island

- White/Caucasian

- Other:

How many full-time faculty members teach in your program?

- Enter Number: 
Identify the percentage of your Master's in PETE faculty who:

Have taught in a contracted teaching position in P-12 settings in physical education?

0-1-2-100\%

Have athletic training/coaching backgrounds?

0-1-100\%

Have teaching backgrounds other than physical education (classroom teaching)?

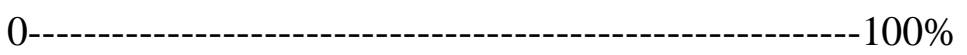

Have exercise science/exercise physiology backgrounds?

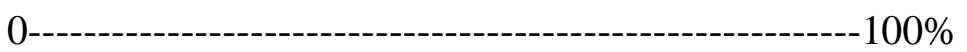

Have sport management backgrounds?

0-1-100\% 


\section{PETE Master's Program Curriculum Information}

Please identify the additional certifications/concentrations available to your master's in PETE candidates

\begin{tabular}{|l|l|l|}
\hline & Available & Required \\
\hline American Council of & & \\
Exercise & & \\
ACSM (American College of & & \\
Instructor & & \\
\hline ACSM Fitness Leader & & \\
\hline Adapted Physical Educator & & \\
\hline CAPE & & \\
\hline Aerobics and Fitness & & \\
Association of America & & \\
\hline Athletic Coaching & & \\
\hline Athletic Training & & \\
\hline CPR/First Aid & & \\
\hline Certified Strength and & & \\
Conditioning Specialist & & \\
\hline Lifeguard & & \\
\hline Outdoor Education & & \\
\hline Water Safety Instructor & & \\
\hline Health & & \\
\hline Exercise Science & & \\
\hline Sport Management & & \\
\hline Athletic Training & & \\
\hline Other: (Specify) & & \\
\hline
\end{tabular}

Does your Master's in PETE program require any coursework specific to the area of adapted physical education/activity (i.e. physical education for individuals with disabilities)?

- Yes

- No

○ If no, skip to technology 


\section{If yes, how is this completed?}

- Covered in an Adapted PE course

- Covered as a topic or unit in another course

- Infused into units/topics in all courses

Is there a hands-on practicum experience associated with any of these adapted courses/requirements?

- Yes

- No

If a practicum experience in adapted physical education/activity is available, in which of the following settings does it take place? Please check ALL that apply.

- On Campus

- Off Campus

- School based Adapted Physical Education

- Community based Adapted Physical Activity (i.e. Special Olympics, Paralympics)

- Camp for individuals with disabilities

- Inclusive program/class (i.e. students with disabilities are taught alongside students without disabilities)

- Specialized or separate program/class for individuals with disabilities

- Other

- Specify Other:

Please describe the coursework, learning experiences, and clinical practice that your program uses to assist candidates to learn about adapted physical education. Please provide documents if available. 
What forms of technology are your PETE candidates TRAINED TO USE:

$\underline{\text { (Please select all) }}$

- Video Editing

- Accelerometers

- DVD Editing

- Electronic Gaming Software (Wii)

- Flip Cameras

- Excel (for grading)

- Grading software (School specific)

- Heart Rate monitors

- Internet websites (Wiki Spaces, Blogs, etc.)

- MacBook software and programs

- Microsoft office

- Music editing and downloading software

- Pedometers

- Portfolio programs (Live Text)

- SKYPE

- Social Networking (Facebook, Twitter)

- SPSS Software

- Video Analysis Software

- Other:

○ Specify Other:

Does your PETE program require any coursework specifically emphasizing multi culturalism or cultural diversity?

- Yes

- No

○ If no, skip to next section

Please describe the coursework emphasizing multiculturalism or cultural diversity included in your PETE curriculum:

$\underline{\text { TEXT BOX HERE }}$ 
Please identify all teaching field experiences available for PETE candidates to PRACTICE teaching

- Adapted Physical Education

- Aquatics

- Aquatics

- Camp

- ESL

- Home School

- International/Study Abroad

- Pre-School

- Classroom Settings

- Rural School

- Suburban School

- Urban School

- University Basic Instruction Program

○ Other:

The culminating experience required in your program is:

- Practicum based (student teaching)

- Research based (Thesis)

- Optional, practicum OR research based

- Other

○ Specify Other 


\section{PETE Master's Program Candidate Information}

Please identify the percentage of Master's in PETE CANDIDATES currently enrolled in your PETE program who identify as:

- Female

- Male

Please identify the percentage of Master's in PETE CANDIDATES currently enrolled in your PETE program who identify as:

- African American

- Hispanic

- Asian

- European

- Native American

- Pacific Island

- White/Caucasian

- Other:

○ Specify Other:

\section{GRADUATING:}

How many candidates typically graduate from your program each year (fall, spring, summer)?

Enter Number:

\section{RECRUITING:}

Does your master's in PETE program actively recruit international or minority students?

- Yes

- No

Does your program actively recruit candidates with disabilities? 
- Yes

- No

Are graduate assistantships available to candidates in your program?

- Yes

- No

○ If no, Skip to the Matrix

Graduate assistant duties in your program include:

(Check as many as applicable)

- Teaching undergraduate PETE classes

- Teaching basic instruction classes

- Supervising undergraduate students

- Research

- Other

○ Specify Other:

Identify the number of current Master's in PETE candidates who:

Are currently teaching physical education in a FULL-TIME position.

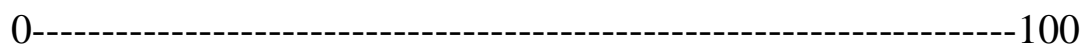

Are currently employed FULL TIME in a field other than education (Sales, Sport Administration, Business, etc.).

0--100

Are currently employed PART TIME in the field of physical education.

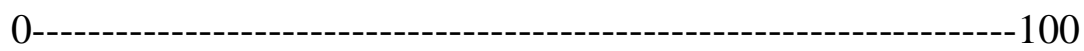

Are currently employed PART TIME in a discipline of education other than physical education.

0--1-100

Are currently serving as graduate assistants within the department.

0----------------------------------------------------------------------100 
Are currently teaching FULL TIME in a field other than physical education (History, Math, etc.)

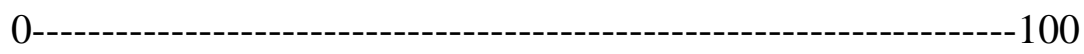

\section{Master's in PETE Program and Application of 2009 SHAPE America (formerly known as NASPE) Advanced Standards}

Indicate all accreditations your PETE program has earned:

- CAEP/SHAPE America

- State Level

○ Other:

Is your program currently following SHAPE America's 2009 Advanced standards for PETE?

- Yes

- No

- Not sure

- If no, skip to end of survey 


\section{How do you assess SHAPE America's Advanced Standard 1, Professional Knowledge? \\ Advanced physical education teacher candidates come to understand disciplinary content knowledge, the application of content knowledge to teaching physical education, and modes of inquiry that form the bases for physical education programs and instruction.}

1a. Check all course(s) in which your program assesses knowledge of content in movement and pedagogy: The TC synthesizes concepts from multiple aspects of both movement and pedagogy and can articulate how that information applies to specific students and contexts.

- Curriculum courses

- Core courses

- Methods courses

- Research courses

- Seminar courses (adapted, multicultural)

- Other

○ Specify Other

Please list the courses and catalog descriptions used to assess elements of 1 a.

\section{TEXT BOX HERE}

Please elaborate on coursework and student experiences/requirements used to assess knowledge of content in movement in pedagogy.

TEXT BOX HERE 
1b. Check all course(s) in which your program assesses knowledge of how to represent content knowledge to make it comprehensible to learners (i.e., pedagogical content knowledge):

Description: The TC knows how to transform the content into understandable forms tailored to the variations in ability and background presented by the learners and the learning context.

- Curriculum course(s)

- Core courses

- Methods courses

- Research courses

- Seminar courses (adapted, multicultural)

- Other

○ Specify Other

Please list the courses and catalog descriptions used to assess elements of $1 b$.

TEXT BOX HERE

Please elaborate on any coursework and student experiences/requirements used to assess knowledge of how to represent content knowledge to make it comprehensible to learners (i.e., pedagogical content knowledge)

TEXT BOX HERE 
1c. Check all courses(s) in which your program assesses knowledge of processes and methods of systematic intentional inquiry about learning and teaching in physical education.

Description: The TC identifies pertinent questions about learning and teaching in physical education, as well as designs processes for collecting, analyzing and interpreting data to answer those questions.

- Curriculum course(s)

- Core courses

- Methods courses

- Research courses

- Seminar courses (adapted, multicultural)

- Other

○ Specify Other

Please list the courses and catalog descriptions used to assess elements of $1 c$.

TEXT BOX HERE

Please elaborate on any coursework and student experiences/requirements used to assess knowledge of processes and methods of systematic intentional inquiry about learning and teaching in physical education.

TEXT BOX HERE 


\section{How do you assess SHAPE America's Advanced Standard 2, Professional Practice? \\ Advanced physical education teacher candidates use content knowledge and pedagogical content knowledge to design and conduct appropriate learning experiences that facilitate and enhance the growth of learners.}

2a. Check all course(s) in which your program assesses teaching as it reflects understanding and application of content knowledge and pedagogical content knowledge appropriate to the learners, the learning environment and long- and short-term outcomes/goals.

Description: The TC demonstrates, through planning and/or instruction, a deep understanding of content knowledge and PCK, and articulates a rationale for instructional choices. Or, TC discovers opportunities to refine or develop new understandings that add to the professional body of knowledge.

- Curriculum course(s)

- Core courses

- Methods courses

- Research courses

- Seminar courses (adapted, multicultural)

- Other

○ Specify Other

Please list the courses and catalog descriptions used to assess elements of $2 a$.

TEXT BOX HERE

Please elaborate on any coursework and student experiences/requirements used to assess teaching as it reflects understanding and application of content knowledge and pedagogical content knowledge appropriate to the learners, the learning environment and long- and shortterm outcomes/goals.

\section{TEXT BOX HERE}


2b. Check all course(s) in which your program assesses teaching as it reflects integration of planning, instruction and assessment as a unified process to achieve long- and short-term outcomes/goals.

Description: The TC uses learners' prior knowledge and personal history (e.g., language, culture, family and community) to plan, implement and assess meaningful learning experiences. AC engages learners in the process of defining long-and shortterm outcomes/goals, designing or choosing learning experiences and monitoring their own learning in ways that are developmentally appropriate.

- Curriculum course(s)

- Core courses

- Methods courses

- Research courses

- Seminar courses (adapted, multicultural)

- Other

○ Specify Other

Please list the courses and catalog descriptions used to assess elements of $2 b$.

\section{TEXT BOX HERE}

Please elaborate on any coursework and student experiences/requirements used to assess teaching as it reflects integration of planning, instruction and assessment as a unified process to achieve long- and short-term outcomes/goals.

TEXT BOX HERE 
2c. Check all course(s) in which your program assesses teaching as it reflects differentiation of instruction based on personal and cultural characteristics of learners.

Description: The TC establishes a learning environment that respects and celebrates learners' diverse experiences and approaches to learning. AC uses multiple strategies to engage learners in appropriate opportunities that promote development of performance capabilities, critical-thinking skills and/ or the ability to recognize their own needs and seek experiences to meet those needs.

- Curriculum course(s)

- Core courses

- Methods courses

- Research courses

- Seminar courses (adapted, multicultural)

- Other

○ Specify Other

Please list the courses and catalog descriptions used to assess elements of $2 c$.

TEXT BOX HERE

Please elaborate on any coursework and student experiences/requirements used to assess teaching as it reflects differentiation of instruction based on personal and cultural characteristics of learners.

TEXT BOX HERE 
2d. Check all course(s) in which your program assesses teaching as it reflects systematic inquiry about the practice and the learners served.

Description: The TC engages learners in the process of analyzing teaching effectiveness and learning and uses the results of systematic analysis to test hypotheses and generate knowledge according to the methods of inquiry and standards of evidence used in physical education.

- Curriculum course(s)

- Core courses

- Methods courses

- Research courses

- Seminar courses (adapted, multicultural)

- Other

○ Specify Other

Please list the courses and catalog descriptions used to assess elements of $2 d$.

TEXT BOX HERE

Please elaborate on any coursework and student experiences/requirements used to assess teaching as it reflects systematic inquiry about the practice and the learners served.

TEXT BOX HERE 


\section{How do you assess Shape America's Advanced Standard 3, Professional Leadership?}

Advanced physical education teacher candidates are continuous, collaborative learners who further their own professional development and use their abilities to contribute to the profession.

3a. Check all course(s) in which your program assesses inquiry into professional knowledge and practice and communicates results of inquiry to the profession and community.

Description: The TC questions professional knowledge and practice by conducting formal inquiry into teaching and learning. TC seeks formal means of sharing findings with the profession as a whole and/or advocating for instructional and school improvement.

- Curriculum course(s)

- Core courses

- Methods courses

- Research courses

- Seminar courses (adapted, multicultural)

- Other

○ Specify Other

Please list the courses and catalog descriptions used to assess elements of $3 a$.

TEXT BOX HERE

Please elaborate on any coursework and student experiences/requirements used to assess inquiry into professional knowledge and practice and communicates results of inquiry to the profession and community.

\section{TEXT BOX HERE}


3b. Check all course(s) in which your program assesses the continuation of personal development through contributions to the growth and professional learning of others.

Description: The TC contributes to the development of all involved through sustained formal curricular and/or instructional support to fellow professionals by serving as a mentor or instructional coach, or in other leadership roles.

- Curriculum course(s)

- Core courses

- Methods courses

- Research courses

- Seminar courses (adapted, multicultural)

- Other

○ Specify Other

Please list the courses and catalog descriptions used to assess elements of $3 b$.

TEXT BOX HERE

Please elaborate on any coursework and student experiences/requirements used to assess the continuation of personal development through contributions to the growth and professional learning of others.

TEXT BOX HERE 


\section{Appendix E}

Interview Guide:

1. Please discuss features of your program that were not described in the survey.

\section{Probes:}

- Are there any features unique to your program?

- Are there features that you attribute to the success of your program?

- Describe how are students recruited into your program.

2. Discuss how your program as a whole incorporates/teaches the importance of the focus on learning rather than teaching.

Probes:

- Please provide specific examples.

- Is the focus on learning rather than teaching assessed over the course of the entire program?

- How is this done?

- Can you provide specific examples?

- Is the importance of the focus on learning rather than teaching stressed more in specific courses/areas/years (steps) than others?

3. Discuss your how your program as a whole incorporates an integrated knowledge base (advanced teacher must possess an integrated body of knowledge and skills).

\section{Probes:}

- Please provide specific examples.

- Is an integrated knowledge base assessed over the course of the entire curriculum?

- How is this done?

- Is the importance of an integrated knowledge base stressed more in specific courses/areas/years (steps) of the program than others?

4. Discuss how your program evaluates/discusses/incorporates the importance of inquiry in teaching (reflection).

Probes:

- Please provide specific examples.

- Is the importance assessed/discussed/evaluated over the course of the entire curriculum?

- How is this done?

- Is the importance inquiry stressed more in specific courses/areas/years (steps) of the program than others? 
5. Discuss how your program evaluates/incorporates the role of leadership in teaching.

Probes

- Please provide specific examples.

- Is the importance of leadership roles in teaching discussed/evaluated over the course of the entire curriculum?

- Is the importance of leadership in teaching stressed more in specific courses/areas/years (steps) of the program than others?

6. Please identify where you envision the program (major trends and issues) moving forward. Probes:

- Where do you see your program in 5 years?

- Describe major vs. minor changes.

- Please describe rationale behind these potential changes.

- What strategies have been employed to retain students in your program? 


\section{Appendix F}

Email Recruitment for Interview Phase

Hello

My name is Jamie Gilbert. You are receiving this email because you have recently completed a survey regarding your master's in PETE program as part of my doctoral dissertation through West Virginia University. I would like to thank you for your participation in the first phase of my dissertation study.

The purpose of my study is to provide a descriptive analysis of PETE master's programs in the U.S. and their adherence to SHAPE America's advanced standards. I have attached interview questions for you to review at your convenience.

The interview will be audio recorded, but all information will be kept confidential and stored on a password-protected file. Should publication result from this study, no identifying information will be published. Participation in this interview process is voluntary and you may withdraw at any point. This study has been reviewed and I have received permission to conduct it from West Virginia University's Institutional Review Board.

Once you have had a chance to review the interview questions, please respond indicating a time that works best for you to complete the phone interview. If you have any questions, please do not hesitate to contact me via email at jkgilbert@mix.wvu.edu. Thank you for your time.

Sincerely,

Jamie Gilbert 